DANIELLE CARLOMAGNO GONÇALVES DE SÁ

\title{
A REPERCUSSÃO GERAL DA QUESTÃO CONSTITUCIONAL: UMA ANÁLISE CRÍTICA
}

Dissertação apresentada à Comissão Julgadora
da Faculdade de Direito da Universidade de São
Paulo, como exigência parcial para obtenção do
título de Mestre em Direito Processual, sob a
orientação do Professor Doutor Walter Piva
Rodrigues.

Universidade de São Paulo

Faculdade de Direito

São Paulo, 2014 
Banca Examinadora

$\overline{x+300}$

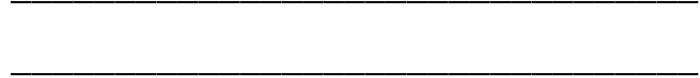


Aos meus pais,

Cristiane e Ayres,

por tudo,

sempre. 


\section{RESUMO}

A presente Dissertação de Mestrado buscará analisar as origens, causas e implicações da crise que assola o Supremo Tribunal Federal há décadas, além de analisar de que forma o instituto da Repercussão Geral se propõe a tentar soluciona-la - e se, de fato, tem conseguido.

Originariamente concebido como guardião e garantidor da Constituição Federal, o STF sofreu graves distorções em sua função, ao ser constantemente chamado a adjudicar sobre matérias repetidas e de relevância duvidosa.

No ano de 2007, aportaram ao Supremo Tribunal Federal Tribunal Federal mais de 56.000 (cinqüenta e seis mil) agravos de instrumento e quase 50.000 (cinqüenta mil) recursos extraordinários, provocando um enorme acúmulo de trabalho e uma verdadeira crise institucional.

O surgimento - e agravamento - dessa crise tem muitas razões: (i) o contexto histórico-cultural em que a Constituição Federal de 1988 foi promulgada; (ii) a amplitude do espectro de questões passíveis de julgamento pelo STF, após a extinção dos obstáculos então existentes à interposição de recursos; (iii) a falta de aparelhamento técnico do Poder Judiciário e, ainda, (vi) a amplitude de nosso sistema recursal.

Tal situação se explica pelo anseio de democratização do acesso à Justiça, que levou o constituinte a, de um lado, ampliar o quadro de competências do STF, aumentando enormemente o número de controvérsias passíveis de ser objeto de recursos extraordinários e criando uma séria desproporção entre o número de Ministros e de processos distribuídos; e, de outro lado, eliminar os critérios distintivos das demandas levadas à apreciação do Supremo Tribunal Federal, ao extinguir a então vigente arguição de relevância.

Diante da ineficiência dos mecanismos adotados para solucionar essa crise, surgiu a necessidade de criar e implementar um verdadeiro filtro recursal, capaz de represar as demandas de pouca expressividade e permitir que o Supremo Tribunal Federal desempenhasse uma função mais assemelhada à de Corte Constitucional brasileira.

Inúmeras tentativas foram feitas com o fito de estabelecer um critério distintivo de seleção das questões levadas à apreciação do Supremo Tribunal Federal.

A arguição de relevância, criada pela Emenda Constitucional no 7, de 1977, ainda na vigência da Constituição Federal de 1967, que vigorou por cerca de treze anos, e a transcendência, que vigora, hoje, como requisito de admissibilidade de demandas de revista 
trabalhistas, previsto pelo art. 896-A da CLT, foram os mais significativos instrumentos criados com o intuito de filtrar os recursos submetidos ao crivo do Supremo Tribunal Federal.

Esses mecanismos foram inspirados em institutos bem-sucedidos em diversos ordenamentos jurídicos ao redor do mundo, tais como o writ of certiorari norte-americano, a rechtssache grundsätzlichen bedeutung alemã e a gravedad institucional argentina, além de institutos semelhantes presentes em outros países, como o Reino Unido, Canadá, Austrália e Japão.

Assim, concebida a partir de experiências anteriores e inspirações internacionais, com o intuito de funcionar como um mecanismo seletor das demandas que aportam ao Supremo Tribunal Federal, foi instituída a Repercussão Geral da questão constitucional, um novo requisito intrínseco de admissibilidade dos recursos extraordinários.

Esse novo instituto pretendeu criar um filtro de seleção dos recursos extraordinários a serem julgados pelo Supremo Tribunal Federal a partir dos critérios de relevância e abrangência do tema em discussão. Em outras palavras, apenas os temas que encontram ampla repercussão nos âmbitos jurídico, político, econômico ou social estão aptos a serem apreciados pelo STF.

A despeito de todas as dificuldades hermenêuticas que a vagueza desses termos conceituais pode ensejar, a intenção declarada do instituto de Repercussão Geral é fazer com que o Supremo Tribunal Federal desempenhe uma função mais assemelhada à de Corte Constitucional, afastando de sua jurisdição temas de menor importância, para que seus Ministros possam se debruçar sobre as questões verdadeiramente relevantes à sociedade.

É isso o que o presente estudo se propõe a realizar: uma análise crítica do instituto da Repercussão Geral, sua definição teórica e aplicação prática.

Criado pela Emenda Constitucional $n^{\circ} 45$ e regulamentado pela Lei $n^{\circ}$ 11.418/2006, o instituto da Repercussão Geral, por opção do próprio legislador, é de difícil conceituação concreta, por ser indeterminado e bastante vago. Como se verá, a ausência de conceito exato e bem delimitado parece permitir, no entanto, que os textos normativos acompanhem, de perto, a complexidade das relações humanas e sociais, além de restaurar a valorização das demais fontes do Direito, como formas de complementar e suprir as lacunas de cada caso concreto.

Outro ponto analisado é a irrecorribilidade da decisão que afastar a alegada existência de Repercussão Geral. A previsão de tão radical consequência implica em cerceamento de defesa da parte recorrente? Contribuiu para o avanço de posições ditatoriais e autoritárias? Como solucionar, por exemplo, um erro de enquadramento de um determinado 
recurso extraordinário, reputado erroneamente como desprovido de Repercussão Geral? Há alguma forma de, ainda assim, alçar o tema ao conhecimento da Corte Suprema?

As respostas a essas perguntas revelarão, além da dimensão de efetividade prática do instituto da Repercussão Geral, a potencial rejeição pela sociedade e a corrida a diversos mecanismos técnicos capazes de "burlar" as decisões proferidas pelo Supremo Tribunal Federal Tribunal Federal.

Para que se tenha uma noção mais fiel da atual realidade do Judiciário brasileiro, este estudo apresenta a análise de dados, números e estatísticas fornecidos pelo próprio Supremo Tribunal Federal, em seus relatórios anuais e boletins periódicos, acerca da implementação do instituto da Repercussão Geral da questão constitucional.

Com efeito, parece ser mesmo inegável que a quantidade de recursos submetidos à apreciação e julgamento do Supremo Tribunal Federal diminuiu - e muito - desde o efetivo funcionamento desse novo filtro seletor de demandas.

Vemos, então, que este sistema de filtragem não terá apenas a tarefa de diminuir a carga de trabalho submetida aos Tribunais Superiores, mas também se revelará um instrumento de aperfeiçoamento da jurisdição constitucional, melhorando e acelerando a distribuição da Justiça.

Estamos, portanto, hoje, diante de um novo cenário do Poder Judiciário brasileiro; com a paulatina adoção de uma estrutura apta a acolher as demandas formuladas e solucionálas de forma mais efetiva e célere, o Supremo Tribunal Federal pode voltar a atuar como o verdadeiro guardião da Magna Carta.

Palavras-chave: Repercussão Geral; filtro de admissibilidade; recurso extraordinário; arguição de relevância. 


\begin{abstract}
This Master's Thesis will analyze the origins, causes and implications of the crisis involving the Brazilian Federal Supreme Court for decades, in addition to analyzing how does the general repercussion principle tries to solve it and if it has actually succeed to do so.

Originally conceived as a guardian and guarantor of the Federal Constitution, the Federal Supreme Court (STF) has suffered serious distortions in its duties when being constantly called to judge repetitive matters of doubtful relevance.

In the year 2007, more than fifty-six thousand (56,000) Interlocutory Appeals and almost fifty thousand $(50,000)$ Extraordinary Appeals were filed with the Federal Supreme Court which, resulted in an enormous accumulation of work and an actual institutional crisis.

The appearance - and aggravation - of this crisis has many reasons: (i) the historical and cultural context in which the 1988 Federal Constitution was enacted; (ii) the wide array of matters subject to trial by the STF after the extinguishment of the then existing hindrances to the filing of appeals; (iii) the lack of technical equipment of the Judicial Branch and, furthermore, (vi) the extent of our appeal system.

Such situation is explained by the longing for democratization of access to Justice, which led the constitutional lawmaker to, on the one side, amplify the powers of the STF, highly increasing the number of disputes which may be subject to extraordinary appeals and creating a serious lack of proportion between the number of Justices and the number of cases assigned to them; meanwhile, on the other hand, eliminate the distinctive criteria of the actions submitted to the Supreme Court by extinguishing the motion of relevance then in effect.

In view of the inefficiency of the mechanisms adopted to solve this crisis, there was the need to create and implement an actual filter for the appeals, which should be able to stop the flow of irrelevant actions and to allow the Supreme Court to resume its essential duties such as a Brazilian Constitutional Court.

Many attempts at establishing a distinctive criteria for selection of the matters submitted to the analysis of the Federal Supreme Court have been made.

The motion of relevance, created by Constitutional Amendment No. 7, of 1977, and which was effective for about thirteen years, and the transcendence, which is currently in effect as a requirement for admissibility of labor claims, as provided in article 896-A of the
\end{abstract}


Consolidated Labor Laws (CLT) were the most significant instruments created to filter the appeals submitted to the Federal Supreme Court for analysis.

These mechanisms were inspired in successful principles in several legal systems around the world, such as the North-American writ of certiorari, the German rechtssache grundsätzlichen bedeutung and the Argentinean gravedad institucional, in addition to similar principles existing in other countries, such as United Kingdon, Canada, Australia and Japan.

Thus, the general repercussion of constitutional matters, conceived from previous experiences and international inspirations to operate as a mechanism to select the claims submitted to the Federal Supreme Court, was created as a new intrinsic requirement of admissibility of extraordinary appeals.

This purpose of the new principle was to create a selection filter of the extraordinary appeals to be decided by the Federal Supreme Court based on the criteria of relevance and scope of the matters under discussion. In other words, only the matters with great repercussion in the legal, political, economic and social spheres may be analyzed by our Supreme Court.

Irrespective of all interpretation difficulties resulting from the vagueness of such conceptual terms, the declared intention of the principle of general repercussion is to cause the Federal Supreme Court to resume its duties such as a Constitutional Court, removing matters of minor importance from its jurisdiction, so that its Justices may focus on the matters that are truly relevant to society.

And this is the purpose of this study: a critical analysis of the general repercussion principle, its theoretical definition and practical application.

The principle of General Repercussion, which as created by Constitutional Amendment No. 45 and regulated by Law No. 11.418/2006, is difficult to define due to the fact that it is undetermined and very vague. The inexistence of a well determined and exact definition allows the normative texts to closely follow the complexity of the social and human relationships, in addition to restoring the valorization of the other sources of Law as manners of supplementing and filling gaps of each specific case.

Another issue to be carefully analyzed shall be the unappealableness of the decision which denies the claim of existence of general repercussion. Does the provision of such a radical consequence imply the denial of the opportunity of appellant to be heard? Has it contributed to the advance of dictatorial and authoritarian positions? How to solve, for instance, an error of classification of a certain extraordinary appeal wrongly reputed as devoid 
of general repercussion? Is there a way of, even so, submit the matter to the Supreme Court for analysis?

The answers to these questions will reveal, in addition to the dimension of the practical effectiveness of the general repercussion principle, the potential rejection by the society and the reach to several technical mechanisms able to "circumvent" the decisions issued by the Federal Supreme Court.

In order to have closer notion of the actual reality of the Brazilian Judicial Branch, this study presents the analysis of data, numbers and statistics supplied by the Federal Supreme Court itself in its annual reports and periodical bulletins regarding the implementation of the principle of general repercussion of constitutional matters.

In fact, it is actually undeniable that the number of appeals submitted to the Federal Supreme Court for analysis and trial has been reduced - a lot - since the actual application of this new filter to select cases.

Therefore, we note that this filtering system will not only have the task to reduce the load of work submitted to the Higher Courts, but it will also be revealed as an instrument of improvement of the constitutional jurisdiction, improving and accelerating the assignment of Justice.

Thus, today we have a new scenario of the Brazilian Judicial Branch; with the slow adoption of a structure able to entertain the claims made and to resolve them in more effectively and swiftly, and the Federal Supreme Court may act again as the true guardian of the Brazilian Constitution.

Key-words: general repercussion of constitutional matters; preliminary judgement; extraordinary appeal; writ of certiorari. 


\section{SUMÁRIO}

1 INTRODUÇÃO

p. 12

\section{O PROBLEMA HISTÓRICO DA SOBRECARGA DE TRABALHO}

E A CRISE INSTITUCIONAL DO SUPREMO TRIBUNAL FEDERAL

p. 16

2.1 A necessidade de desempenho, pelo Supremo Tribunal Federal, de uma função mais assemelhada à de Corte Constitucional p. 19

2.2 As tentativas de superação da crise do Supremo Tribunal Federal e a criação de mecanismos seletores de recursos

p. 23

2.2.1 A chamada "jurisprudência defensiva" p. 25

$\begin{array}{ll}\text { 2.2.2 A arguição de relevância } & \text { p. } 27\end{array}$

$\begin{array}{ll}\text { 2.2.3 O requisito da transcendência no recurso de revista } & \text { p. } 33\end{array}$

3 A REPERCUSSÃO GERAL DA QUESTÃO CONSTITUCIONAL p. 37

$\begin{array}{ll}3.1 \text { Os aspectos legais } & \text { p. } 38\end{array}$

3.1.1 A Emenda Constitucional n $n^{\circ} 45$ e o art. 102, $\S 3^{\circ}$, da Constituição

$\begin{array}{ll}\text { Federal de } 1988 & \text { p. } 38\end{array}$

3.1.2 A Lei n ${ }^{\circ}$ 11.418/06, arts. 543-A e 543-B do Código de Processo Civil e as Emendas ao Regimento Interno do Supremo Tribunal Federal p. 40

3.2 Os aspectos teóricos p. 46

3.2.1 O conceito jurídico indeterminado de "Repercussão Geral" p. 46

3.2.2 A natureza jurídica da Repercussão Geral: novo requisito de admissibilidade $\begin{array}{ll}\text { do recurso extraordinário } & \text { p. } 56\end{array}$

3.2.3 As principais finalidades da Repercussão Geral - declaradas e reais p. 63

$\begin{array}{ll}3.3 \text { Os aspectos práticos } & \text { p. } 69\end{array}$

3.3.1 A presunção absoluta prevista pelo artigo 543-A, § $3^{\circ}$, do Código $\begin{array}{ll}\text { de Processo Civil p. } 69 & \text { p }\end{array}$

3.3.2 A presunção relativa prevista pelo artigo 324, parágrafo $1^{\circ}$, do Regimento Interno do Supremo Tribunal Federal: a hipótese de reconhecimento tácito da Repercussão Geral p. 71

3.3.3 A intervenção do amicus curiae para o reconhecimento da Repercussão Geral p. 73 
3.4 Os aspectos polêmicos

p. 81

3.4.1 A admissibilidade e o julgamento do mérito de recurso extraordinário que versa sobre diferentes questões constitucionais

p. 81

3.4.2 A irrecorribilidade da decisão relativa à ausência da Repercussão Geral

p. 83

3.4.3 A extensão do instituto da Repercussão Geral aos recursos especiais submetidos ao julgamento do Superior Tribunal de Justiça

p. 87

\section{AS INSPIRAÇÕES INTERNACIONAIS}

p. 91

$4.1 \mathrm{O}$ writ of certiorari norte-americano

p. 92

4.2 A rechtssache grundsätzlichen bedeutung alemã

p. 98

4.3 A gravedad institucional argentina

p. 100

4.4 Outros países: Inglaterra, Canadá, Austrália e Japão

p. 103

5 ANÁLISES ESTATÍSTICAS

p. 107

6 CONCLUSÕES

p. 114

REFERÊNCIAS BIBLIOGRÁFICAS

p.118 


\section{INTRODUÇÃO}

Em prosseguimento aos estudos realizados na Tese de Láurea $A$ Repercussão Geral como mecanismo de aperfeiçoamento da jurisdição nacional, defendida em dezembro de 2009, esta Dissertação analisará as origens, causas e implicações da crise que assola o Supremo Tribunal Federal (STF) há décadas, além de perquirir de que forma o instituto da Repercussão Geral se propõe a soluciona-la - e se, de fato, tem conseguido.

Originariamente concebido como guardião da Constituição Federal, o Supremo Tribunal Federal sofreu graves distorções em sua função, ao ser constantemente chamado a judicar sobre matérias repetidas e de relevância duvidosa.

No ano de 2007, aportaram ao STF mais de 56.000 (cinquenta e seis mil) agravos de instrumento e quase 50.000 (cinquenta mil) recursos extraordinários, provocando um enorme acúmulo de trabalho e uma verdadeira crise institucional.

O surgimento - e agravamento - dessa crise tem muitas razões: (i) o contexto histórico-cultural em que a Constituição Federal de 1988 foi promulgada; (ii) a amplitude do espectro de questões passíveis de julgamento pelo Supremo Tribunal Federal, após a extinção dos obstáculos então existentes à interposição de recursos; (iii) a falta de aparelhamento técnico do Poder Judiciário e, ainda, (vi) a amplitude de nosso sistema recursal.

Tal situação se explica, em certa medida, pelo anseio de democratização do acesso à Justiça, que levou o constituinte a, de um lado, ampliar o quadro de competências do Supremo Tribunal Federal, aumentando enormemente o número de controvérsias passíveis de ser objeto de recursos extraordinários e criando uma séria desproporção entre o número de Ministros e de processos distribuídos; e, de outro lado, eliminar os critérios distintivos das demandas levadas à apreciação do STF, ao extinguir a então vigente arguição de relevância.

Diante da ineficiência dos mecanismos adotados para solucionar essa crise, surgiu a necessidade de criar e implementar um verdadeiro filtro recursal, capaz de represar as demandas de pouca expressividade e permitir que o Supremo Tribunal Federal desempenhasse uma função mais assemelhada à de Corte Constitucional brasileira.

Inúmeras tentativas foram feitas com o fito de estabelecer um critério distintivo de seleção das questões levadas à apreciação do Supremo Tribunal Federal.

A arguição de relevância, criada pela Emenda Constitucional n ${ }^{\circ}$ 7, de 1977, ainda na vigência da Constituição Federal de 1967, que vigorou por cerca de treze anos, e a transcendência, que vigora, hoje, como requisito de admissibilidade de demandas de revista 
trabalhistas, previsto pelo art. 896-A da Consolidação das Leis do Trabalho (CLT), foram os mais significativos instrumentos criados com o intuito de filtrar os recursos submetidos ao crivo do Supremo Tribunal Federal.

Além deles, a súmula vinculante, prescrita pelo art. 103-A da CF/1988; o recurso de cassação, previsto pelo $\S 3^{\circ}$ do art. 103-A da CF/1988, aplicável quando a decisão recorrida apresentar graves errores in procedendo ou afrontar súmula vinculante, o recurso per saltum, semelhante ao pedido de "uniformização de interpretação de lei federal", no âmbito dos Juizados Especiais Federais, o incidente de inconstitucionalidade, atuante no controle difuso ou incidental de normas, descrito nos artigos 480 a 482 do Código de Processo Civil, e o incidente de uniformização, previsto pelos artigos 476 a 479 do Código de Processo Civil.

Esses mecanismos foram inspirados em institutos bem sucedidos em outros ordenamentos jurídicos, tais como o writ of certiorari norte-americano, a rechtssache grundsätzlichen bedeutung alemã e a gravedad institucional argentina, além de institutos semelhantes adotados por outros países, como o Reino Unido, Canadá, Austrália e Japão.

Concebida, assim, a partir de experiências anteriores e inspirações internacionais, foi instituída a Repercussão Geral da questão constitucional, um novo requisito intrínseco de admissibilidade dos recursos extraordinários.

Esse novo instituto pretendeu criar um filtro de seleção dos recursos a serem julgados pelo Supremo Tribunal Federal, a partir dos critérios de relevância e abrangência do tema em discussão. Em outras palavras, apenas os temas dotados de ampla repercussão nos âmbitos jurídico, político, econômico ou social estão, agora, aptos a serem apreciados pelo STF.

A despeito de todas as dificuldades hermenêuticas que a vagueza desses termos conceituais pode ensejar, a intenção declarada do instituto de Repercussão Geral é fazer com que o Supremo Tribunal Federal desempenhe uma função mais assemelhada à de Corte Constitucional, afastando de sua jurisdição temas de menor importância, para que seus Ministros possam dedicar seu tempo e seu trabalho a questões verdadeiramente relevantes à sociedade.

Contudo, seria mesma essa a real intenção desse instituto? Não estaria a Repercussão Geral verdadeiramente destinada a criar mais um filtro seletor de demandas deixado ao arbítrio de seus próprios julgadores? Não estaria ela fadada ao insucesso, como dizem as críticas direcionadas à sua aplicação e consequências práticas, como a que sustenta a instituição de mais um óbice ao acesso à Justiça? 
É isso o que o presente estudo se propõe a realizar: uma análise crítica do instituto da Repercussão Geral, sua definição teórica e sua aplicação prática.

Uma das principais questões a ser enfrentada nessa Dissertação diz respeito à vagueza terminológica da expressão "Repercussão Geral" e suas implicações no âmbito prático da aplicação do instituto.

Criado pela Emenda Constitucional $n^{\circ} 45$ e regulamentado pela Lei $n^{\circ}$ 11.418/2006, o instituto da Repercussão Geral, por opção do próprio legislador, é de difícil conceituação concreta, por ser indeterminado e bastante vago. Como se verá, a ausência de conceito exato e bem delimitado parece permitir, no entanto, que os textos normativos possam acompanhar a complexidade das relações humanas e sociais, além de restaurar a valorização das demais fontes do Direito, como formas de complementar e suprir as lacunas de cada caso concreto.

Com a evolução das pesquisas e na posse de dados mais recentes e atualizados acerca da aplicação prática da Repercussão Geral, será analisado o impacto que tamanha subjetividade na caracterização da Repercussão Geral - bem como sua abrangência conceitual - pode provocar na efetiva redução da efetividade prática desse instituto.

Outro ponto a ser analisado é a irrecorribilidade da decisão que afasta a alegada existência de Repercussão Geral. A previsão de tão radical consequência implica em cerceamento de defesa da parte recorrente? Contribuiu para o avanço de posições ditatoriais e autoritárias? Como solucionar, por exemplo, um erro de enquadramento de um determinado recurso extraordinário, reputado erroneamente como desprovido de Repercussão Geral? Há alguma forma de, ainda assim, alçar o tema ao conhecimento do Supremo Tribunal Federal?

As (tentativas) de respostas a essas perguntas revelarão, além da dimensão da efetividade prática do instituto da Repercussão Geral, a eventual rejeição pela sociedade e a busca de diversos mecanismos técnicos capazes de "burlar" as decisões proferidas pelo Supremo Tribunal Federal.

Além disso, a análise das mais recentes estatísticas fornecidas pelo próprio Supremo Tribunal Federal, em seus relatórios anuais e boletins periódicos, trarão à cena os resultados numéricos da instituição deste novo requisito intrínseco de admissibilidade dos recursos extraordinários, para que se possa perquirir a resposta à seguinte indagação: se o sistema alargar por demasiado o entendimento do que vem a ser "relevância econômica, política, social ou jurídica", estaríamos sujeitos, uma vez mais, ao problema da sobrecarga do Supremo Tribunal Federal? 
Diante de tal quadro, faz-se necessário um estudo detalhado acerca da possibilidade e viabilidade de uma restrição legal, no bojo da própria Constituição Federal, quanto aos temas que devem ser tidos por dotados de Repercussão Geral, e se isso, de fato, representaria um melhor filtro às demandas submetidas à análise do Supremo Tribunal Federal. Ainda, tal hipótese deverá ser devidamente contrastada e sopesada com os riscos de engessamento do sistema, rigidez das normas interpretativas, violação da garantia fundamental de acesso à justiça e até mesmo de interesses políticos.

Como se verá, parece ser inegável que a quantidade de recursos submetidos à apreciação e julgamento do Supremo Tribunal Federal diminuiu desde o efetivo funcionamento desse novo filtro seletor de demandas ${ }^{1}$, que terá não apenas a tarefa de diminuir a carga de trabalho submetida aos Tribunais Superiores, mas também a de servir como um instrumento de aperfeiçoamento da jurisdição constitucional.

Estamos, portanto, hoje, diante de um novo cenário do Poder Judiciário brasileiro: com a adoção de uma estrutura apta a acolher as demandas formuladas e solucioná-las de forma mais efetiva e célere, o Supremo Tribunal Federal pode voltar a atuar como o verdadeiro guardião da Magna Carta. 


\section{O PROBLEMA HISTÓRICO DA SOBRECARGA DE TRABALHO E A CRISE INSTITUCIONAL DO SUPREMO TRIBUNAL FEDERAL}

O Supremo Tribunal Federal vem sofrendo, ao longo das últimas décadas, grave distorção de sua função. Cada vez mais, diferentes matérias são submetidas à sua apreciação, ainda que de relevância duvidosa, provocando um enorme acúmulo de trabalho e uma verdadeira crise institucional.

E são muitas as razões para o surgimento - e agravamento - dessa crise.

Um dos principais fatores causadores da crise do Supremo Tribunal Federal está no próprio recurso extraordinário: seu amplo espectro de cabimento, sua abrangência temática e a possibilidade de sua interposição sem maiores óbices fez com que a crise do Supremo Tribunal Federal fosse chamada por muitos de "a crise do recurso extraordinário",

O ordenamento jurídico brasileiro prevê, desde as Constituições de 1891 e $1934^{3}$, a competência da União para legislar sobre direito civil, comercial, penal e processual, o que faz com que as Instâncias Ordinárias apliquem, diuturnamente, legislação de caráter federal, cuja uniformização cabia, em última instância, aos Tribunais Superiores ${ }^{4}$. Nesse sentido, as palavras de José Miguel Garcia MEdinA:

"Como foi demonstrado, o recurso extraordinário teve como modelo o writ of error do direito norte-americano; ressaltou-se, também, que não se atentou, à época, para uma grande diferença existente entre os dois países: a competência legislativa federal, no Brasil, é ampla, ao contrário do que ocorre no direito norte-americano, onde tal competência é bem mais restrita. Como o recurso extraordinário tinha a peculiaridade de ser exercitável em qualquer causa na qual estivesse presente a questão federal (aqui abrangidas as questões constitucionais e as questões federais propriamente ditas), é compreensível que se tenha verificado um grande número de recursos distribuídos ao Supremo

\footnotetext{
${ }^{2}$ Nas palavras do Ministro José Carlos Moreira Alves: "O que se convencionou denominar a crise do Supremo Tribunal Federal e que, em verdade, é a crise do recurso extraordinário, deu margem a uma série de providências legais e regimentais para que a Corte não soçobrasse em face do volume de recursos que a ela subiam". (Cf. O Supremo Tribunal Federal em face da nova Constituição - Questões e Perspectivas, p. 1).

3 Já àquela época, era possível antever a dimensão da crise de sobrecarga que assolaria o Supremo Tribunal Federal. A esse respeito, destaca Bruno Dantas, em referência à obra de Filadelfo de Azevedo, que "com base nos relatórios de atividades do STF, entre os anos de 1925 e 1934, a média de recursos extraordinários interpostos não alcançava sequer uma centena, ao passo que, nos primeiros anos da década de 1940, ultrapassava a casa do milhar." (Cf. Repercussão Geral: perspectivas históricas, dogmática e de direito comparado: questões processuais, p. 87).

${ }^{4}$ Sobre o tema, afirma Rodolfo de Camargo Mancuso: "Visto que o recurso extraordinário tinha a peculiaridade de ser exercitável em qualquer dos ramos do direito objetivo onde houvesse 'questão federal' ou 'questão constitucional', é compreensível que nessa alta Corte para logo se tenha instalado um formidável acúmulo de processos, moléstia que, por causa da demora no tratamento, tornou-se crônica, passando a ser referida como a 'crise do Supremo Tribunal Federal”' (Cf. Recurso Extraordinário e Recurso Especial, p. 67).
} 
Tribunal Federal, problema que, por causa da demora em sua resolução, tornou-se crônico, passando a ser referido como 'a crise do Supremo Tribunal Federal'.",

Ademais, há que se notar que a Constituição Federal de 1988 foi concebida e promulgada ao final da Ditadura Militar no Brasil, vigente entre os anos de 1964 e 1985, tempos em que centenas de cidadãos clamavam ter seus direitos violados por um governo imposto e tido por antidemocrático.

Nesse contexto histórico-cultural, os anseios populares acabaram por influenciar o texto constitucional que estava sendo criado, o que explica a amplitude e a abrangência do rol de direitos fundamentais que, segundo a nova Magna Carta, deveriam ser assegurados, garantidos e protegidos pelo novo Estado Democrático de Direito. Isso aumentou a diversidade e a quantidade das matérias passíveis de análise e julgamento pelo Supremo Tribunal Federal ${ }^{6}$.

De outro lado, a despeito de ter ampliado o espectro de questões aptas a serem julgadas pelo Supremo Tribunal Federal, deixou a Magna Carta de prever a criação de qualquer obstáculo à interposição de recursos extraordinários, além de extinguir os já existentes, como a arguição de relevância.

A falta de aparelhamento técnico do Poder Judiciário também contribui, em grande parte, para o agravamento da crise. A falta de investimentos - tanto do ponto de vista

\footnotetext{
5 Cf. Prequestionamento e Repercussão Geral e outras questões relativas aos recursos especial e extraordinário, p. 45.

${ }^{6}$ Nesse sentido, Ricardo de Barros Leonel justifica a crise do Supremo Tribunal Federal, em certa medida, à amplitude das matérias constitucionalizadas: "Na prática, podemos afirmar que boa parte das demandas judiciais tem, direta ou indiretamente, algum fundamento ou reflexo de ordem constitucional. E o resultado da constitucionalização dos litígios, como não poderia deixar de ser, é o recrudescimento do número de casos em que, seja pela via do controle concentrado de constitucionalidade, seja por meio do controle difuso, a discussão chega a o Pretório Excelso. O resultado disso é que o STF, literalmente 'perdido' no exercício de suas funções e no exame dos milhares de casos que the chegam periodicamente, sofre de 'crise de identidade', e acaba minimizando seu mais importante papel em detrimento de outras funções que deveriam ser acometidas exclusivamente às instâncias ordinárias da Justiça brasileira." (Cf. Reformas recentes do Processo Civil comentário sistemático, p. 167).

E a análise pelo Supremo Tribunal Federal das questões de cunho constitucional fica quase que restrita à interposição de recursos extraordinários, graças à restrita legitimidade para a propositura de demandas relativas ao controle concentrado de constitucionalidade, como alerta Guilherme Beux Nassif Azem: "Por outro lado, a impossibilidade, via ação direta de inconstitucionalidade ou ação direta de constitucionalidade, de proceder à análise de determinadas matérias (interpretação direta de cláusulas constitucionais pelos juízes e tribunais, direito pré-constitucional, controvérsia constitucional sobre normas revogadas e controle de constitucionalidade do direito municipal em face da Constituição Federal), aliada à restrita legitimidade para o ajuizamento da arguição de descumprimento de preceito fundamental, demonstra a existência de um extenso espaço residual ao recurso extraordinário no controle de constitucionalidade, no qual se revela frequente a repetição de processos." (Cf. Repercussão Geral: perspectivas históricas, dogmática e de direito comparado: questões processuais, p. 22).
} 
de recursos humanos, quanto de recursos materiais - obsta o necessário desenvolvimento e atualização do sistema judiciário brasileiro.

Profissionais mal treinados e, muitas vezes, inaptos para as funções que exercem, representam uma porcentagem cada vez maior dos gastos do Poder Público, sem que isso se reverta em resultados positivos. E mais: a despeito da criação do processo eletrônico ${ }^{7}$, ainda se vê a utilização, em larga escala, de uma obsoleta tecnologia para o processamento dos feitos, o que prolonga indesejadamente a duração do processo e agrava a sensação social de ineficiência da Justiça ${ }^{8}$.

Além disso, o acúmulo de recursos pendentes de julgamento pelo Supremo Tribunal Federal deve-se, também, à amplitude do sistema recursal previsto em nosso ordenamento jurídico, que acaba por permitir a perpetuação do inconformismo das partes vencidas, que continuam a tentar obter, mediante a interposição de novos e novos recursos, o reexame de decisões que lhe foram desfavoráveis.

Isso provoca certa confusão acerca do verdadeiro sentido da garantia processual do duplo grau de jurisdição. Partes e seus patronos tendem a interpretá-lo como uma longa e interminável cadeia de recursos, que se esgota, tão somente, com o pronunciamento definitivo do STF. Essa mentalidade acabou por transformar o Supremo Tribunal Federal e o Superior Tribunal de Justiça em meras instâncias recursais, às quais cumpre reexaminar toda e qualquer decisão já prolatada, sobre os mais variados assuntos.

Explicitadas algumas das causas, é preciso destacar, também, os efeitos da chamada crise do Supremo Tribunal Federal.

No âmbito jurídico, a massificação das decisões e a perda da qualidade da prestação jurisdicional é um dos reflexos da sobrecarga de processos submetidos ao STF. Sobre o tema, alerta RoDOLFO DE CAMARGO MANCUSO:

"Essas cifras expressivas não reduzem o problema a uma crise meramente numérica ou quantitativa, devendo-se, ao contrário, ter presente que a 'quantidade afeta a qualidade'. Por isso, quando um órgão judicial postado à cumeeira da organização judiciária recebe mais processos do que pode julgar, começam as mazelas que desprestigiam a Justiça e afligem os jurisdicionados: protraimento indefinido dos feitos, contrariando a garantia da duração razoável

\footnotetext{
${ }^{7}$ Cf. Lei no $11.419 / 2006$.

${ }^{8}$ Nesse sentido, vale destacar os resultados de uma pesquisa realizada pelo Supremo Tribunal Federal junto aos Tribunais Ordinários, que afirmaram que suas principais dificuldades se devem à ausência de (i) espaço físico, como relataram TJ/PA, TJ/PI, TJ/RS, TJ/PR, TRF $4^{\mathrm{a}}$ Região, TJ/SC - $3^{\mathrm{a}} \mathrm{VP}$ e TRF - $2^{\mathrm{a}}$ Região; e (ii) pessoal para gerenciar os processos, segundo TJ/PA, TJ/PI, TJ/RS, TJ/PR e TRF $4^{\text {a }}$ Região. Informações disponíveis em http://www.stf.jus.br/arquivo/cms/jurisprudenciaRepercussaoGeralRelatorio/anexo/Resultados_apresentados.pdf, p. 67. Acesso em 02 de janeiro de 2014.
} 
(CF, art. 5, LXXVIII - EC 45/2004); funcionarização do Judiciário, contrariando o disposto no art. 93, XIV, da CF - EC 45/2004; massificação da resposta judiciária, em detrimento do exame cuidadoso de cada caso e da consistente fundamentação jurídica da decisão."9

Além disso, a falta de segurança jurídica e a demora na entrega da prestação jurisdicional provocam reflexos negativos também à economia nacional e à sociedade civil ${ }^{10}$. Não é difícil perceber que o aumento do número de recursos extraordinários submetidos ao crivo do Supremo Tribunal Federal acaba por retardar a entrega definitiva da prestação jurisdicional, o que provoca um aumento nos custos do processo e, comumente, a prolação de decisões discrepantes a respeito de um mesmo tema constitucional, colocando em xeque o ideal de segurança jurídica.

Por essas razões, e temendo o progresso de seus perniciosos efeitos, ganhou força a ideia da necessidade de criação de mecanismos capazes de fazer com que o Supremo Tribunal Federal assumisse um papel mais assemelhado à de Corte Constitucional, responsável pela unidade do ordenamento jurídico nacional e salvaguarda da Constituição Federal.

2.1 A necessidade de desempenho, pelo Supremo Tribunal Federal, de uma função mais assemelhada à de Corte Constitucional

Enquanto órgão de cúpula do Poder Judiciário brasileiro, o Supremo Tribunal Federal tem a atribuição, expressamente prevista, de salvaguarda da Constituição Federal e preservação da constitucionalidade (de forma difusa ou concentrada ${ }^{11}$ ) e unidade do ordenamento jurídico nacional.

\footnotetext{
${ }^{9}$ Cf. Recurso Extraordinário e Recurso Especial, p. 73 - destaques no original.

10 "De qualquer ângulo pelo qual se analise a história recente do Supremo Tribunal Federal, não há como refutar que a inviabilização de seu funcionamento, efetivo e real, tem gerado irritações insuportáveis nos subsistemas funcionais que integram a sociedade. Irritações negativas que, p. ex., no sistema da economia são traduzidas e comunicadas como 'prejuízos econômicos' ligados à falta de celeridade, de segurança jurídica e de utilidade prática das decisões judiciais (...). E, também, dos custos financeiros ligados à manutenção de organizações judiciárias (tribunais e varas judiciais) que acabem por inviabilizar, por 'falta de recursos', políticas públicas no campo dos direitos sociais." (Cf. Repercussão Geral sob a ótica da teoria dos sistemas de Niklas Luhmann, p. 208).

11 "O controle é difuso porque pode ser feito por qualquer órgão jurisdicional; ao controle difuso contrapõe-se o concentrado. Chama-se de controle concreto, porque feito a posteriori, à luz das peculiaridades do caso; a ele se contrapõe o controle abstrato, em que a inconstitucionalidade é examinada em tese, a priori. Normalmente, o controle abstrato é feito de forma concentrada, no STF, por intermédio da ADIN, ADC ou ADPF, e o controle concreto, de forma difusa. O controle difuso é sempre incidenter tantum, pois a constitucionalidade é questão incidente, que será resolvida na fundamentação da decisão judicial; assim, a decisão a respeito da questão somente tem eficácia inter partes. O controle concentrado, no Brasil, é feito principaliter tantum, ou seja, a questão sobre a constitucionalidade da lei compõe o objeto litigioso do processo e a decisão a seu respeito ficará
} 
A ele cumpre garantir a uniformidade e a observância ao direito objetivo da jurisprudência nacional, estabelecendo diretrizes e fixando posicionamentos que deverão ser adotados por todas as demais Instâncias hierarquicamente inferiores ${ }^{12}$, de modo a alcançar o ideal de unidade e inteireza do direito positivo brasileiro e encontrar soluções e respostas adequadas aos novos problemas e anseios sociais ${ }^{13}$.

Sobre o tema, LuIZ GUILHERME MARINONI E DANIEL MitidiERO:

"Aos tribunais podem ser reconhecidas basicamente duas funções: (i) resolver controvérsias ('resolution of disputes') e (ii) enriquecer o estoque de normas jurídicas ('enrichment of the supply of legal rules'). Em um sistema ideal de organização judiciária, pode-se dizer que os órgãos jurisdicionais ordinários devem cuidar da solução das controvérsias, sendo responsabilidade das Cortes Superiores o resguardo da uniformidade e a promoção do desenvolvimento do direito. Dentro dessa linha, é fácil perceber que o primeiro escopo responde à necessidade das partes de ver o seu caso bem apreciado em juízo. Do mesmo modo, é igualmente fácil notar que o segundo escopo não tem esse mesmo endereço, respondendo antes à necessidade de aderência das soluções jurídicas à cultura social - interessando, portanto, mais à sociedade como um todo do que propriamente às partes do processo." ${ }^{, 14}$

Além disso, cumpre ao Supremo Tribunal Federal, também, zelar pelo constante desenvolvimento do Direito e "enriquecer o estoque de normas jurídicas"15, adequando o ordenamento jurídico às novas necessidades sociais e prestando respostas adequadas às novas questões relevantes postas em análise.

imune pela coisa julgada material, com eficácia erga omnes." (Cf. A função do Supremo Tribunal Federal e a força de seus precedentes: enfoque nas causas repetitivas, p. 64).

${ }^{12}$ Nesse sentido, Humberto Theodoro Júnior: "A par disso, busca-se fortalecer a autoridade daquela Corte como guardiã da Constituição, prestigiando sua jurisprudência, como reveladora da última palavra em termos de definição das questões constitucionais, o que, em última análise, pode evitar a continuidade e repetição infinita de causas iguais em todos os niveis do Poder Judiciário." (Cf. Repercussão Geral no Recurso Extraordinário (Lei $\left.n^{o} 11.148\right)$ e Súmula Vinculante do Supremo Tribunal Federal (Lei $\left.n^{o} 11.417\right)$, pp. 101).

13 "Enfim, o papel do Recurso Extraordinário, no quadro dos recursos cíveis, é o de resguardar a interpretação dada pelo STF aos dispositivos constitucionais, garantindo a inteireza do sistema jurídico constitucional federal e assegurando-lhe validade e uniformidade de entendimento." (Cf. A função do Supremo Tribunal Federal e a força de seus precedentes: enfoque nas causas repetitivas, pp. 63-64).

${ }^{14}$ Cf. Repercussão Geral no recurso extraordinário, pp. 15-16. Sobre a função nomofilática do Supremo Tribunal Federal, prosseguem os autores: "Passa-se a colimar às Cortes Superiores não mais o simples objetivo de uniformizar a jurisprudência, antes lhe assinalando o fito de outorgar unidade ao Direito. Especificamente no caso do nosso Supremo Tribunal Federal, outorgar unidade à Constituição e, a partir daí, a todo o Direito brasileiro. Reconhece-se às Cortes Superiores - e ao Supremo Tribunal Federal em particular - um papel próativo, destinado ao futuro e tendo por destinatária a sociedade em geral.” (Cf. op. cit., p. 18).

${ }^{15}$ Cf. Repercussão Geral no recurso extraordinário, p. 15. Trata-se da chamada "dupla perspectiva" do papel do Supremo Tribunal Federal na consecução da unidade do ordenamento jurídico: de um lado, a unidade retrospectiva, voltada à compatibilização das decisões judiciais; e, de outro, a unidade prospectiva, destinada ao desenvolvimento de novas soluções aos problemas sociais. 
No entanto, como visto anteriormente, o vertiginoso aumento do número de recursos destinados à análise e julgamento pelo Supremo Tribunal Federal acabou por afastálo de suas funções primordiais, em razão do grande volume de decisões a serem proferidas e da exigência da duração razoável do processo $^{16}$.

Assim, deve o Supremo Tribunal Federal restringir sua atuação à análise e julgamento de grandes questões, que revelem importância e significado transcendentes - o que, naturalmente, acabará por reduzir, criteriosa e efetivamente, o número de recursos a ele submetidos ${ }^{17}$.

É preciso, portanto, coibir a comum mentalidade da prática jurídica atual de que o Superior Tribunal de Justiça e o Supremo Tribunal Federal constituem mera terceira (e eventual quarta ${ }^{18}$ ) Instância, a quem cabe reexaminar toda e qualquer decisão judicial. Em verdade, os pronunciamentos do STF devem se atentar não aos interesses subjetivos das partes em litígio, mas sim ao interesse público envolvido na questão apreciada ${ }^{19}$.

Nesse sentido, aponta HuMBERTO THEODORO JÚNIOR:

“(...) A missão que lhe é atribuída é de uma carga política maior, é a de propiciar à Corte Suprema meio de exercer seu encargo de guardião da Constituição, fazendo com que seus preceitos sejam corretamente interpretados e fielmente aplicados. É a autoridade e supremacia da Constituição que toca ao STF realizar por via dos julgamentos dos recursos extraordinários.

São as grandes questões da ordem constitucional que a doutrina ocidental aponta como objeto capaz de explicar a instância recursal extraordinária. Sem um filtro prévio que detecte a presença de uma questão nacional em torno da

\footnotetext{
${ }^{16}$ Nesse sentido, destaca Guilherme Beux Nassif Azem: “O grande número de litígios, somado à considerável variedade dos temas suscitados - capazes de desviar a atenção dos julgadores para assuntos menores, em prejuízo da respectiva concentração nas questões de maior relevância -, acabou por afastar o STF do cumprimento de sua missão principal, obscurecendo a avaliação do Tribunal no seu aspecto decisivo - a institucionalização e preservação do Estado Democrático de Direito.” (Cf. op. cit., p. 23).

17 "A redução do tempo na produção das decisões, decorrente da redução numérica dos recursos extraordinários, deverá ser utilizada como instrumento para a geração de efeitos na celeridade e na efetividade - utilidade social como efetivação dos direitos fundamentais e estabilização de expectativas sociais ligadas a funções finalísticas dos demais subsistemas sociais - das decisões a serem produzidas em sede de controle difuso no recurso extraordinário, dotado de Repercussão Geral. Desse modo, o sistema parcial do direito centrado na atuação da organização judiciária do Supremo Tribunal Federal poderá tornar mais eficientes e úteis suas prestações decisórias e gerará efeitos positivos na evolução do sistema social como um todo, por meio de operacionalizações condicionais (criação de condições) ligadas à segurança jurídica e previsibilidade das decisões judiciais no campo dos temas constitucionais com Repercussão Geral que apresentem relevância econômica, política, social e jurídica e que tenham alcance objetivo-sistêmico (que transcende o interesse subjetivo das partes)." (Cf. Repercussão Geral sob a ótica da teoria dos sistemas de Niklas Luhmann, p. 206).

${ }^{18}$ Cf. Repercussão Geral no recurso extraordinário, p. 22.

19 "Inverte-se, pois, no recurso extraordinário, a tradicional lógica recursal: fundamentalmente, são as partes instrumento de uma finalidade maior cometida ao recurso. O interesse privado na reforma ou na cassação da decisão que lhe é desfavorável atua em serviço do interesse público na exata aplicação do direito constitucional, sendo reconhecido e tutelado desde que coincida com o especial interesse coletivo que constitui a base do instituto." (Cf. Guilherme Beux Nassif Azem, op. cit., p. 21).
} 
discussão travada no processo, é inevitável a transformação do Supremo Tribunal Federal numa nova instância recursal. Foi a falta de filtragem da relevância do recurso extraordinário que levou o Supremo Tribunal Federal a acumular anualmente milhares e milhares de processos, desnaturando por completo seu verdadeiro papel institucional e impedindo que as questões de verdadeira dimensão pública pudessem merecer a apreciação detida e ponderada exigível de uma autêntica corte constitucional." 20

Os Tribunais Superiores devem, pois, ser chamados a judicar apenas em hipóteses efetivamente relevantes e essenciais, que transcendam os interesses subjetivos em litígio e exijam um julgamento criterioso, aprofundado e rigorosamente fundamentado.

Surge, então, a necessidade da criação de mecanismos de contenção dos recursos extraordinários, que possibilitariam a seleção das questões verdadeiramente relevantes e, como tais, aptas a terem seu mérito julgado pelo Supremo Tribunal Federal. De acordo com os ensinamentos de Rodolfo DE CAMARGO MANCUSO:

"Em suma, uma Corte Superior, para ofertar uma resposta judiciária de qualidade (que a nosso ver deve preencher estes requisitos: ser justa, jurídica, econômica, tempestiva e razoavelmente previsível), necessita de certos filtros e elementos de contenção porque, do contrário, ou bem não conseguirá gerir a quantidade de processos que a ela afluem, levando ao represamento e ao atraso na prestação jurisdicional, ou bem acabará ofertando resposta judiciária de massa, com evidente prejuízo para os valores segurança e justiça."21

Com o intuito de viabilizar o desempenho, pelo Supremo Tribunal Federal, de uma função mais assemelhada à de Corte Constitucional e diante das falhas dos demais institutos criados com esse propósito, como se verá, foi instituída a Repercussão Geral da questão constitucional, como um novo requisito intrínseco de admissibilidade dos recursos extraordinários $^{22}$.

\footnotetext{
${ }^{20}$ Cf. op. cit., pp. 101-102.

${ }^{21}$ Cf. op. cit., p. 95 - destaques no original.

22 "Daí a oportunidade e o inteiro acerto de instituir-se a Repercussão Geral da controvérsia constitucional como requisito de admissibilidade do recurso extraordinário. Tendo presentes essas coordenadas, a adoção de um mecanismo de filtragem recursal como a Repercussão Geral encontra-se em absoluta sintonia com o direito fundamental à tutela jurisdicional efetiva e, em especial, com o direito fundamental a um processo com duração razoável. Guardam-se as delongas inerentes à tramitação do recurso extraordinário apenas quando o seu conhecimento oferecer-se como um imperativo para a ótima realização da unidade do Direito no Estado Constitucional brasileiro. Resguardam-se destarte, a um só tempo, dois interesses: o interesse das partes ma realização de processos jurisdicionais em tempo justo e o interesse da Justiça no exame de casos pelo Supremo Tribunal Federal apenas quando essa apreciação mostrar-se imprescindível para a realização dos fins a que se dedica a alcançar a sociedade brasileira.” (Cf. Repercussão Geral no recurso extraordinário, pp. 22-23).
} 
Com a implementação desse novo filtro recursal e a consequente diminuição do número de processos pendentes de julgamento, se verá que, finalmente, o Supremo Tribunal Federal pode começar a dar os seus primeiros passos na direção que, hoje, lhe é exigida.

\subsection{As tentativas de superação da crise do Supremo Tribunal Federal e a criação de} $\underline{\text { mecanismos seletores de recursos }}$

Com o objetivo de racionalizar a atividade judicial brasileira e amenizar a crise que assola o Supremo Tribunal Federal, foram realizadas algumas tentativas de barragem à interposição indiscriminada de recursos extraordinários.

Entre elas, destaca-se a exigência de fundamentação da decisão que admite o processamento de recurso extraordinário, nos termos da Lei ${ }^{\circ} 3.396 / 1958^{23}$, e a criação das súmulas de jurisprudência dominante, através da Emenda Regimental de 28 de agosto de $1963^{24}$.

Além disso, especialmente após a promulgação da Constituição Federal de 1988, outra importante medida foi a criação do Superior Tribunal de Justiça, "órgão jurisdicional de cúpula, encarregado de zelar pela inteireza positiva, validade, autoridade e uniformidade exegética do direito federal comum, infraconstitucional: CF de 1988, art. 104",25, a quem incumbe assegurar o respeito à legislação federal e harmonizar as decisões proferidas pelos vinte e sete Tribunais de Justiça dos Estados e do Distrito Federal e Territórios e pelos cinco Tribunais Regionais Federais de nosso país.

Outras tentativas, mais significativas no que tange à obtenção de resultados práticos, foram (i) a criação do regime de retenção dos recursos especiais e extraordinários interpostos contra decisões interlocutórias ${ }^{26}$, o que otimizou o trabalho dos Ministros ao permitir a apreciação dos apelos extraordinários apenas quando já definitivamente julgada a demanda de origem pela Instância inferior; (ii) a ampliação dos poderes concedidos ao

\footnotetext{
${ }^{23}$ À semelhança do que já era exigido para as decisões que inadmitiam o seu processamento.

${ }^{24}$ Nas palavras de José Carlos Moreira Alves, súmula é “a cristalização da jurisprudência do Tribunal, feita por meio de enunciado que sintetiza o princípios fundamental seguido numa série de julgamentos." (Cf. Poder Judiciário, RT 18/18).

${ }^{25}$ Cf. Rodolfo de Camargo Mancuso, op. cit., p. 88.

26 Exceto quando houver risco de iminente dano material ou processual, que justifique o seu pronto conhecimento pelas instâncias superiores. Nesse sentido, a respeito da retenção de recurso especial (em raciocínio análogo ao que deve ser aplicado aos recursos extraordinários): "A regra de obstar o recurso especial retido deve ser obtemperada para que não esvazie a utilidade daquele apelo extremo." (Cf. STJ, $1^{\mathrm{a}}$ Turma, MC $\mathrm{n}^{\mathrm{o}}$ 6.811, Min. José Delgado, j. em 02.12.2003).
} 
Relator, nos termos do art. 557, caput e parágrafo $1^{\circ}$-A, do Código de Processo Civil ${ }^{27}$, para negar seguimento, negar ou dar provimento a recurso extraordinário mediante decisão monocrática, o que também dinamizou a tramitação processual no Supremo Tribunal Federal; e (iii) a eficácia vinculante das súmulas editadas pelo Supremo Tribunal Federal, nos termos da Emenda Constitucional no 45/2004.

Há, ainda, que se notar a adoção de outras técnicas processuais de retenção do volume de recursos extraordinários, materializadas com a edição das Súmulas $n^{\circ}$ s 279, 282, 283 e 284 do Supremo Tribunal Federal. Em síntese, tais enunciados estabelecem (i) o não conhecimento do recurso extraordinário que pretender o reexame fático e probatório, reservando aos Tribunais Superiores a análise exclusiva de questões de direito; (ii) a exigência do prequestionamento da questão constitucional discutida pelas Instâncias inferiores, que exige que os fundamentos fáticos e jurídicos arguidos pelo recurso já tenham sido ventilados nas Instâncias a quo; (iii) o não conhecimento do recurso extraordinário que não impugnar todos os fundamentos invocados pelo decisum recorrido; e (iv) o não conhecimento do recurso extraordinário cuja fundamentação se revele insuficiente à exata compreensão da controvérsia $^{28-29}$.

Embora bem estruturadas e dotadas de algum sucesso, essas modificações não conseguiram, de fato, reduzir a quantidade de recursos dirigidos ao Supremo Tribunal Federal, sobrecarregando, até mesmo, o Superior Tribunal de Justiça, diante do volume excessivo de trabalho.

Diante da ineficiência desses mecanismos, se tornaram ainda mais fortes os apelos para a criação e implementação de um verdadeiro filtro recursal, capaz de represar as demandas de pouca expressividade e afastá-las da jurisdição do Supremo Tribunal Federal ${ }^{30}$.

\footnotetext{
27 “Art. 557. O relator negará seguimento a recurso manifestamente inadmissível, improcedente, prejudicado ou em confronto com súmula ou com jurisprudência dominante do respectivo tribunal, do Supremo Tribunal Federal, ou de Tribunal Superior.

$\S 1^{o}$-A Se a decisão recorrida estiver em manifesto confronto com súmula ou com jurisprudência dominante do Supremo Tribunal Federal, ou de Tribunal Superior, o relator poderá dar provimento ao recurso."

${ }_{28}$ Súmula $\mathrm{n}^{\circ}$ 279: "Para simples reexame de prova não cabe recurso extraordinário."; Súmula no 282: "É inadmissível o recurso extraordinário, quando não ventilada, na decisão recorrida, a questão federal suscitada."; Súmula $\mathbf{n}^{\mathbf{0}}$ 283: "É inadmissível o recurso extraordinário, quando a decisão recorrida assenta em mais de um fundamento suficiente e o recurso não abrange todos eles."; e Súmula no 284: "É inadmissível o recurso extraordinário, quando a deficiência na sua fundamentação não permitir a exata compreensão da controvérsia.".

${ }^{29}$ Cf. Eduardo Cambi, Critério da Transcendência para a admissibilidade do recurso extraordinário (art. 102, § $3^{o}$, da $\left.C F\right)$ : entre a autocontenção e o ativismo do STF no contexto da legitimação democrática da jurisdição constitucional, p. 158.

${ }^{30}$ Sobre a persistência do problema, afirma Rodolfo de Camargo Mancuso: "Mesmo com o advento de filtros, exigências adicionais e outros diversos elementos de contenção (súmula vinculante do STF; cogitada súmula impeditiva de recursos para o STJ - PEC 358/2005; julgamentos por mutirão elou por amostragem de recursos massivos e repetitivos; exigência da Repercussão Geral da questão constitucional para a admissão do RE no
} 


\subsubsection{A chamada "jurisprudência defensiva"31}

Em razão da extinção da antiga arguição de relevância e na falta de outros mecanismos de filtragem dos recursos extraordinários, alguns mecanismos de contenção das demandas foram adotados pelo Supremo Tribunal Federal, na tentativa de restringir a ampla gama de possíveis interpretações do texto constitucional, de formulação vaga e genérica, acerca do cabimento do recurso extraordinário.

São eles, por exemplo, (i) o prequestionamento ${ }^{32}$, que exige que os fundamentos fáticos e jurídicos embasadores do recurso já tenham sido ventilados nas Instâncias Ordinárias; (ii) a ofensa reflexa à Constituição Federal, segundo a qual é vedada a análise primária de normas infraconstitucionais; (iii) o não cabimento de recurso extraordinário contra acórdão que defere medida liminar (Súmula $\mathrm{n}^{\mathrm{o}} 735^{33}$ ); (iv) o não cabimento de recurso extraordinário contra decisão proferida no processamento de precatórios (Súmula $\mathrm{n}^{\mathrm{o}} 733^{34}$ ); e (v) o não cabimento de recurso extraordinário por contrariedade genérica ao princípio da legalidade (Súmula $\mathrm{n}^{\circ} 636^{35}$ ).

A depender do rigor do entendimento adotado pelo julgador, uma interpretação mais restritiva das formalidades exigidas pelos requisitos essenciais de admissibilidade dos recursos pode culminar com a rejeição, in limine, de um grande número de apelos extraordinários.

Nesse sentido, destaca José Manoel DE ARruda Alvim NetTo que

"O assoberbamento destes tribunais tem como contraponto a imposição de requisitos rigorosos à análise de recursos constitucionais, tais como a

STF), ainda assim a crise numérica, em torno de setenta milhões de processos judiciais em andamento, é suficientemente eloquente para embasar a inferência de que, por um lado, por aí se está a cuidar das consequências, deixando em aberto as causas do excessivo e notório demandismo judiciário, e, por outro lado, pesem os meritórios esforços, não tanto se espera solucionar o problema, mas sim administrá-lo, ou seja: tentar, por todos os meios, evitar que a enorme massa judiciária descambe para uma situação de caos irreversível." (Cf. op. cit., p. 91).

${ }^{31}$ Sobre o tema, discorreu José Manoel de Arruda Alvim Netto em artigo intitulado STF rumo à flexibilização da jurisprudência defensiva. (Cf. disponível em http://www.oab.org.br/noticia/24648/artigo-stf-rumo-aflexibilizacao-da-jurisprudencia-defensiva).

${ }^{32}$ Nesse sentido, são as súmulas $\mathrm{n}^{\circ} 282$ : "É inadmissível o recurso extraordinário, quando não ventilada, na decisão recorrida, a questão federal suscitada" e $\mathrm{n}^{\circ}$ 356: "O ponto omisso da decisão, sobre o qual não foram opostos embargos declaratórios, não pode ser objeto de recurso extraordinário, por faltar o requisito do prequestionamento".

${ }^{33}$ Súmula $n^{\circ} 735$ : "Não cabe recurso extraordinário contra acórdão que defere medida liminar".

34 Súmula $\mathrm{n}^{\circ}$ 733: "Não cabe recurso extraordinário contra decisão proferida no processamento de precatórios".

35 Súmula $\mathrm{n}^{\circ}$ 636: "Não cabe recurso extraordinário por contrariedade ao princípio constitucional da legalidade, quando a sua verificação pressuponha rever a interpretação dada a normas infraconstitucionais pela decisão recorrida”. 
necessária ratificação dos recursos interpostos antes dos Embargos de Declaração, o formalismo no preenchimento de guias de preparo recursal e a impossibilidade de se corrigirem vícios sanáveis" ${ }^{36}$

Contudo, mesmo a utilização, em maior escala, daquilo que parte da doutrina chama de "jurisprudência defensiva" - entendida como o extremo rigor do julgador na análise da admissibilidade dos recursos - não se mostrou suficientemente eficaz na tentativa de reduzir, ou mesmo conter, o volume de feitos submetidos à apreciação do Supremo Tribunal Federal. Nas palavras de UlisSES SchWARZ ViANA:

"O fato é que mesmo com a jurisprudência defensiva, e sua posterior evolução, não se logrou a pretendida redução, em níveis de razoável operacionalidade decisória (celeridade), dos recursos interpostos ao Supremo Tribunal Federal. Talvez em razão da proliferação dos recursos internos (agravos regimentais, embargos de declaração, etc.), bem como pelos efeitos intra processum (nos autos do recurso) e inter partes (subjetivos) das decisões denegatórias de seguimento dos recursos, o que não gerava efeitos sistêmicos e abrangentes, pois eram produzidos caso a caso." ${ }^{37}$

À luz de tal realidade fática, e diante das inúmeras críticas oferecidas à chamada "jurisprudência defensiva" - que, ainda hoje, causa certa perplexidade entre juristas e doutrinadores - fez-se necessária a criação de um novo instituto, que funcionaria como um verdadeiro mecanismo de seleção dos recursos extraordinários.

\subsubsection{A arguição de relevância}

A polêmica arguição de relevância foi a primeira tentativa brasileira de instituir um filtro seletor às demandas que aportavam ao Supremo Tribunal Federal, à semelhança de mecanismos adotados pelos sistemas norte-americano e alemão, como se verá adiante.

Através da Emenda Regimental no 3/1975 à Constituição Federal de 1967 calcada no permissivo trazido pela Emenda Constitucional $n^{\circ} 1 / 1969$, que conferiu ao Supremo Tribunal Federal competência legislativa para indicar, em seu Regimento Interno, as causas que não seriam por ele apreciadas, em razão da matéria discutida ou do valor

\footnotetext{
${ }^{36} \mathrm{Cf}$. STF rumo à flexibilização da jurisprudência defensiva.

${ }^{37}$ Cf. Repercussão Geral sob a ótica da teoria dos sistemas de Niklas Luhmann, p. 26.
} 
envolvido, ainda que satisfeitos todos os demais requisitos de admissibilidade -, o Supremo Tribunal Federal fixou um rol de causas que, a princípio, não seriam julgadas ${ }^{38}$.

Em resposta às inúmeras críticas de que o Supremo Tribunal Federal estaria usurpando a competência que lhe fora constitucionalmente atribuída, a Emenda Constitucional n ${ }^{\circ}$ 7/1977, também à Constituição Federal de 1967, deu nova redação ao parágrafo único do art. 119 dessa Constituição Federal (renumerado como parágrafo $1^{\text {o }}$ ), prevendo, expressamente, que o critério de relevância passava a integrar o rol de elementos de discricionariedade para o exame de admissibilidade dos recursos extraordinários ${ }^{39}$.

Contudo, diante da ampla discricionariedade constitucionalmente atribuída ao Supremo Tribunal Federal, a partir da edição da Emenda no 2/85 ao seu Regimento Interno (RISTF), o raciocínio de aplicação do critério de relevância foi invertido: passou o Supremo Tribunal Federal a prever as hipóteses em que os recursos extraordinários seriam efetivamente apreciados, sendo que, para as causas não expressamente previstas neste rol, apenas seria cabível o recurso extremo se demonstrada a relevância da questão federal ${ }^{40}$.

\footnotetext{
38 “Art. 308. Salvo nos casos de ofensa à Constituição ou relevância da questão federal, não caberá recurso extraordinário, a que alude o seu artigo 119, parágrafo único, das decisões proferidas:

I. Nos processos por crime ou contravenção a que não sejam cominadas penas de multa, prisão simples ou detenção, isoladas, alternadas ou acumuladas, bem como as medidas de segurança com eles relacionadas;

II. Nos habeas corpus, quando não trancarem a ação penal, não lhe impedirem a instauração ou a renovação, nem declararem a extinção da punibilidade;

III. Nos mandados de segurança, quando não julgarem o mérito;

IV. Nos litígios decorrentes:

a) De acidente de trabalho;

b) Das relações de trabalho mencionadas no artigo 110 da Constituição;

c) Da previdência social;

d) Da relação estatutária de serviço público, quando não for discutido o direito à constituição ou subsistência da própria relação jurídica fundamental;

V. Nas ações possessórias, nas de consignação em pagamento, nas relativas à locação, nos procedimentos sumaríssimos e nos processos cautelares;

VI. Nas execuções por título judicial;

VII. Sobre extinção do processo, sem julgamento de mérito, quando não obstarem a que o autor intente de novo a ação;

VIII. Nas causas cujo valor, declarado na petição inicial, ainda que para efeitos fiscais, ou determinado pelo juiz, se aquele for inexato ou desobediente aos critérios legais, não exceda de 100 vezes o maior salário mínimo vigente no País, na data de seu ajuizamento, quando uniformes as decisões das instâncias ordinárias; e de 50, quando entre elas tenha havida divergência, ou se trate de ação sujeita à instância única."

39“"Art. $119(\ldots) \S 1^{\circ}$ As causas a que se referem o item II, alíneas a e d, deste artigo serão indicadas pelo Supremo Tribunal Federal no regimento interno, que atenderá à sua natureza, espécie, valor pecuniário e relevância da questão federal."

40 "Art. 325. Nas hipóteses das alíneas a e d do inciso III do art. 119 da Constituição Federal, cabe recurso extraordinário:

I. $\quad$ Nos casos de ofensa à Constituição Federal;

II. Nos casos de divergência com a Súmula do Supremo Tribunal Federal;

III. Nos processos por crime a que seja cominada pena de reclusão;

IV. Nas revisões criminais dos processos de que trata o inciso anterior;

V. $\quad$ Nas ações relatias à nacionalidade e aos direitos políticos;

VI. Nos mandados de segurança julgados originariamente por Tribunal Federal ou Estadual, em matéria de mérito;
} 
Sobre essa questão, as palavras de BRUNO DANTAS:

"Com isso, alterou-se também o escopo da arguição de relevância das questões federais. No novo modelo, em vez de viabilizar a inclusão daquelas espécies negativamente citadas, a relevância passou a funcionar como 'válvula de escape', criando uma hipótese genérica de cabimento do RE, ao lado das hipóteses específicas arroladas nos incisos I a X do art. 325 do RISTF."41

Vale notar que, muito embora tenha se proposto a criar um rol expresso de hipóteses de cabimento do recurso extraordinário, o Supremo Tribunal Federal também se preocupou em não engessar definitivamente o sistema, ao prever, no último inciso do art. 325 de seu Regimento Interno, a hipótese ampla e genérica de cabimento do apelo extremo a partir de todos os feitos em que restar demonstrada a relevância da questão federal discutida. É possível dizer, portanto, que essa foi uma tentativa de sistematização não taxativa, nem excludente.

Surgiu, então, a necessidade de definição conceitual da chamada "relevância da questão federal", razão pela qual o próprio Supremo Tribunal Federal, no parágrafo $1^{\circ}$ do art. 327 de seu Regimento Interno, a definiu como "a questão federal que, pelos reflexos na ordem jurídica, e considerados os aspectos morais, econômicos, políticos ou sociais da causa, exigir a apreciação do recurso extraordinário pelo Tribunal”.

Nesse sentido, as palavras de GuILHERME BeuX NASsif AzEM:

"Não houve, pelo STF, uma definição de quais seriam os elementos constitutivos da relevância; houve, em verdade, uma indicação de valores suscetíveis de tutela, para o fim de poder ser arguida - e, eventualmente, acolhida - a relevância da questão federal". ${ }^{42}$

Também nesse momento, passou-se a exigir a devida fundamentação da decisão do Supremo Tribunal Federal a respeito da relevância, ou não, da questão tratada no recurso extraordinário.

VII. Nas ações populares;

VIII. Nas ações relativas ao exercício de mandato eletivo federal, estadual ou municipal, bem como às garantias da magistratura;

IX. Nas ações relativas ao estado das pessoas, em matéria de mérito;

$\mathrm{X}$. Nas ações rescisórias, quando julgadas procedentes em questão de direito material;

XI. Em todos os demais feitos, quando reconhecida a relevância da questão federal."

${ }^{41}$ Cf. Repercussão Geral: perspectivas históricas, dogmática e de direito comparado: questões processuais, p. 268.

${ }^{42}$ Cf. Repercussão Geral da questão constitucional no Recurso Extraordinário, p. 53. 
Como se verá a seguir, muitas são as semelhanças entre a antiga arguição de relevância e o atual instituto da Repercussão Geral, as quais, contudo, guardam também algumas diferenças notáveis ${ }^{43}$.

A primeira diferença reside no campo de atuação desses dois institutos: a Repercussão Geral objetiva restringir as hipóteses de cabimento do recurso extraordinário, enquanto a arguição de relevância operava óbices atinentes, principalmente, às questões federais envolvidas - as questões constitucionais não se submetiam a esse crivo ${ }^{44}$.

A arguição de relevância era discutida, em regra, em incidente próprio, autuado em apartado ao recurso extraordinário e com procedimento específico ${ }^{45}$; ao contrário, a Repercussão Geral dispensa a instauração de incidente específico, sendo analisada de forma preliminar ao mérito recursal, ainda no âmbito do juízo de admissibilidade.

Ademais, o acolhimento da arguição de relevância assentava-se no voto proferido em sessão secreta do Plenário - de quatro Ministros, enquanto a inexistência da Repercussão Geral só será declarada com a manifestação, pública e motivada, de oito membros do Supremo Tribunal Federal.

Por fim, ao passo em que a arguição de relevância era vista como um mecanismo de inclusão do recurso extraordinário, a priori excluído da apreciação do Supremo Tribunal Federal, a atual Repercussão Geral tem cunho restritivo e funciona como um requisito excludente do cabimento do recurso extraordinário.

Nesse sentido, as palavras de Rodolfo DE CAMARGo MANCUSO:

“A arguição de relevância configurava um expediente vocacionado à inclusão de recurso extraordinário (para alcançar 'os demais feitos', dizia a primitiva redação do inciso XI do art. 325 do RISTF), em contraposição à atual Repercussão Geral da questão constitucional (CF, § $3^{\circ}$ do art. 102 - EC $45 / 2004)$ a qual, embora bastem quatro votos para ser reconhecida (CPC, $\S 4^{\circ}$ do art. 543-A: Lei 11.418/2006), apresenta índole restritiva, por se apresentar como um pré-requisito genérico e excludente, agregado como um plus às demais exigências para a admissão do RE. Dito de outro modo, não parece razoável que o constituinte revisor, visando claramente aliviar a sobrecarga de

\footnotetext{
${ }^{43}$ Segundo Araken de Assis, apesar da aparente semelhança, esses dois institutos apresentam particularidades diametralmente opostas, de modo que "as marcantes diferenças entre os mecanismos pré-excluem a assimilação, no todo ou em parte, da Repercussão Geral à figura da argüição de relevância” (cf. op. cit., pp. 709 e 710$)$.

${ }^{44}$ Cf. Eduardo Talamini, Novos aspectos da jurisdição constitucional brasileira: Repercussão Geral, força vinculante, modulação dos efeitos do controle de constitucionalidade e alargamento do objeto do controle direto, p. 28.

${ }^{45}$ Muito embora fosse essa a regra à época, havia quem admitisse que a relevância fosse arguida em um capítulo autônomo do apelo (cf. Ives Gandra da Silva Martins Filho in Critério de Transcendência no recurso de revista - Projeto de Lei n. 3.267/00, conforme se verá com detalhes adiante).
} 
trabalho do STF, viesse a excogitar um expediente para... facilitar o acesso a essa Corte, via recurso extraordinário. Não há mal, assim, em dizer que a Repercussão Geral é uma rentrée da arguição de relevância, mas... com o farol trocado!" 46

Também a respeito do tema, é o posicionamento de EDUARDO DE AVELAR LAMY:

"A arguição de relevância tinha objetivo de justificar o conhecimento do recurso extraordinário que não seria admitido segundo as taxativas hipóteses de cabimento. Por sua vez, a Repercussão Geral é instituto que possui o objetivo de possibilitar o não conhecimento do mesmo recurso, caso possa não haver reflexo da referida decisão junto à sociedade. Logo, o antigo instituto buscava a inclusão, enquanto o atual justifica a exclusão, de feição bastante pragmática: uma alternativa ao congestionamento do STF."

Tal como acontece, hoje, com a Repercussão Geral, o reconhecimento da relevância da questão não ensejava o automático conhecimento do recurso extraordinário, que ainda deveria passar pela análise da presença dos demais requisitos - genéricos e específicos - de admissibilidade para, então, ser processado e julgado pela Corte Suprema.

Nas palavras de ARRUdA AlviM:

"O acolhimento da arguição de relevância, por ser ato político, circunscrito a essa finalidade de remoção do óbice, é estranho à juridicidade da admissão, em si mesma, do RE, e, a fortiori, ao seu mérito, e, daí não predeterminar o resultado do julgamento da admissibilidade; apenas possibilita que haja esse julgamento de admissibilidade. É, apenas, ato-condição para que possa haver esse julgamento e, se positiva a admissibilidade, o julgamento do mérito do RE." 48

Nesse mesmo sentido, entendeu o Ministro José Carlos Moreira Alves, no $1^{\circ}$ Ciclo de Palestras Jurídicas do CEAC - Centro de Atividades Culturais, realizado em 30 de mio de 2001, ao destacar que o julgamento da arguição de relevância, dotado de ampla discricionariedade, não deveria ser tido por uma prestação jurisdicional propriamente dita, mas sim por "um juízo de delibação, prévio ao próprio julgamento da causa, no sentido de se apurar se sua relevância recomenda a sua apreciação pelo STF. É, na verdade, um ato político, como o que se faz na ADIn, pois não se trata de aplicar a lei a um caso concreto." 49

\footnotetext{
${ }^{46}$ Cf. Recurso Extraordinário e Recurso Especial, p. 74 - destaques no original.

${ }^{47} \mathrm{Cf}$. Repercussão Geral no recurso extraordinário: a volta da arguição de relevância?, pp. 178-179.

${ }^{48} \mathrm{Cf}$. A arguição de relevância no recurso extraordinário, p. 170.

${ }^{49}$ Cf. Ives Gandra da Silva Martins Filho, in Critério de Transcendência no recurso de revista - Projeto de Lei n. 3.267/00. O Ministro Moreira Alves desenvolve esse raciocínio, chegando à conclusão (um tanto quanto
} 
Da mesma forma, não se cogitava da possibilidade de alteração da decisão recorrida através do julgamento da arguição de relevância: não era ela tida por meio de impugnação das decisões judiciais, nem tinha ela o condão de servir como o recurso extraordinário propriamente dito. Dizia, a esse respeito, SÉRGIO BERMUDES que a arguição “não visa, ela mesma, a modificar a decisão recorrida, mas, apenas, a remover o obstáculo à prolação do juízo positivo de admissibilidade do recurso extraordinário. "50

A despeito das críticas feitas à época - principalmente pela classe dos advogados, que sustentava que a arguição de relevância representaria um óbice ilegítimo ao acesso à Justiça, através de um procedimento complexo e oneroso -, o antigo instituto da arguição de relevância cumpriu, adequadamente, a função de criar um filtro ao cabimento de recursos extraordinários, de modo a permitir que o Supremo Tribunal Federal detivesse sua análise às questões consideradas realmente relevantes, cuja solução extrapolava o interesse subjetivo das partes e importava à coletividade.

Isso fica ainda mais claro quando analisados os números e dados estatísticos da arguição de relevância: em treze anos, cerca de 30.000 (trinta mil) arguições de relevância foram apreciadas pelo Supremo Tribunal Federal, das quais apenas 5\% (cinco por cento) foram acolhidas ${ }^{51}$.

Em que pese o bom funcionamento e inegável êxito na redução do volume de processos submetidos ao crivo do Supremo Tribunal Federal, a arguição de relevância foi extinta com a promulgação da Constituição Federal de 1988, com a criação do Superior Tribunal de Justiça.

A nova Corte, competente para julgar e uniformizar a interpretação das questões federais infraconstitucionais, seria composta por 33 (trinta e três) novos Ministros, o que fez com que o constituinte considerasse que o mecanismo de filtragem representado pela arguição de relevância não seria mais necessário, eliminando-o, portanto, do ordenamento jurídico ${ }^{52}$.

radical e arriscada) de que, por não se tratar de uma decisão judicial propriamente dita, o julgamento da arguição de relevância sequer precisaria ser fundamentado e motivado, tendo em vista a inaplicabilidade do disposto pelo art. 93, IX, da Constituição Federal. Contudo, mesmo essa fundamentação cai por terra à luz do teor do art. 93, $\mathrm{X}$, da Constituição Federal, segundo o qual mesmo as decisões administrativas devem ser motivadas e proferidas em sessão pública.

${ }^{50}$ Cf. Comentários ao Código de Processo Civil, p. 302.

${ }^{51}$ Cf. Ives Gandra da Silva Martins Filho, idem.

${ }^{52}$ A respeito desse equivocado raciocínio, lembrou Rodolfo de Camargo Mancuso das proféticas palavras do Ministro Moreira Alves: "A impossibilidade da instituição de instrumento como a arguição de relevância será um dos fatores que, em espaço de tempo não muito dilatado, inviabilizara a atuação eficaz do STJ em face da amplitude que o projeto da Constituição deu ao recurso especial. Não há Corte alguma que, sem algumas centenas de juízes, possa julgar, em terceiro grau de jurisdição, todas as questões de direito já apreciadas pelo duplo grau de jurisdição ordinária, aplicando, ademais, ao caso concreto, a interpretação dos textos legais pertinentes que se lhe afigura melhor.” (Cf. Recurso Extraordinário e Recurso Especial, p. 77). 
A falta de clareza conceitual, o excesso de subjetivismo, a apreciação em sessões administrativas e secretas e a ausência de motivação das decisões proferidas foram outras causas apontadas para o declínio da arguição de relevância. Ademais, é sabido que algumas razões políticas também motivaram a extinção desse instituto, visto como fruto de décadas de Ditadura Militar no Brasil e, por tal razão, taxado de antidemocrático. Sobre o tema, expõe HUMBERTO THEODORO JÚNIOR:

"O problema é antigo e universal. A Constituição anterior o enfrentou por meio do mecanismo então denominado 'arguição de relevância'. Por se tratar de remédio concebido durante a ditadura militar, a reconstitucionalização democrática do País, levada a efeito pela Carta de 1988, a repeliu por completo, ao invés de aprimorá-la ou substituí-la por outro meio de controle que desempenhasse a mesma função, mas de maneira mais adequada ao Estado Democrática de Direito." 53

É sabido, contudo, que a criação do Superior Tribunal de Justiça não resolveu o problema da sobrecarga das Instâncias Extraordinárias - que, pelo contrário, tem se agravado nos últimos anos -, razão pela qual se mostrou necessária a (re) instituição de um mecanismo seletor de demandas a serem apreciadas pelo Supremo Tribunal Federal ${ }^{54}$.

Após essa breve análise, e a partir do quanto será exposto a seguir, será possível perceber que o instituto da Repercussão Geral da questão constitucional guarda grande semelhança com a extinta arguição de relevância, seu antecedente histórico nacional.

\subsubsection{O requisito da transcendência no recurso de revista}

A crise institucional de que tratamos aqui não é, infelizmente, privilégio exclusivo do Supremo Tribunal Federal: também o Tribunal Superior do Trabalho (TST), enquanto Instância Extraordinária, tem enfrentado problemática semelhante, em razão do grande volume de processos e recursos submetidos anualmente à sua análise.

Em 2013, 244.600 (duzentos e quarenta e quatro mil e seiscentos) processos foram julgados pelo TST, o que significa que, em média, cada um de seus Ministros julgou cerca de 9.673 (nove mil, seiscentos e setenta e três) processos nesse ano ${ }^{55}$.

\footnotetext{
${ }^{53}$ Cf. Repercussão Geral no Recurso Extraordinário (Lei $\left.n^{o} 11.148\right)$ e Súmula Vinculante do Supremo Tribunal Federal (Lei $\left.n^{\circ} 11.417\right)$, p. 102.

${ }^{54}$ Daí porque muitos doutrinadores falam de "retorno da arguição de relevância", ainda que sob novo rótulo.

55 Cf. dados extraídos do site do Tribunal Superior do Trabalho, em http://www.tst.jus.br/home//asset_publisher/eVj1/content/numero-de-processos-que-chegam-ao-tst-cresce-24-7-em-umano?redirect=http $\% 3 \mathrm{~A} \% 2 \mathrm{~F} \% 2 \mathrm{Fwww}$. tst.jus.br\%2Fhome $\% 3 \mathrm{Fp} \_p \_i d \% 3 D 101 \_I N S T A N C E \_e V j 1 \% 26 p \_p \_l i f e c y$
} 
O recurso de revista, submetido ao julgamento do Tribunal Superior do Trabalho, tem suas hipóteses de cabimento delineadas pela Consolidação das Leis do Trabalho (CLT), em seu art. 896: (i) interpretação de dispositivo de lei federal diversa da que lhe houver dado outro Tribunal Regional, no seu Pleno ou Turma, ou a Seção de Dissídios Individuais do Tribunal Superior do Trabalho, ou a Súmula de Jurisprudência Uniforme do TST; (ii) divergência de interpretação de lei estadual, Convenção Coletiva de Trabalho, Acordo Coletivo, sentença normativa ou regulamento empresarial de observância obrigatória em área territorial que exceda a jurisdição do Tribunal Regional prolator da decisão recorrida; e, ainda, (iii) violação literal de lei federal ou afronta direta à Constituição Federal.

É cediço, ademais, que os recursos de revista devem observar as mesmas diretrizes impostas aos recursos extraordinários direcionados ao Supremo Tribunal Federal, quais sejam (i) a vedação de discussão de matéria fático-probatória, (ii) a necessidade de demonstração do prequestionamento e (iii) a satisfação dos requisitos de admissibilidade.

Contudo, tais vedações também não foram suficientes para conter o avanço do problema da sobrecarga também da Justiça do Trabalho. Daí a criação do requisito da transcendência, como filtro ao processamento e julgamento de recursos de revista pelo Tribunal Superior do Trabalho.

O requisito da transcendência, previsto legalmente pelo art. 896-A da CLT ${ }^{56}$, é, nas palavras de IVES GANDRA DA SILVA MARTINS FILHO, uma "pré-condição de admissibilidade do recurso de revista" no Tribunal Superior do Trabalho.

Também de forma genérica e vaga ${ }^{57}$, a discricionariedade do requisito da transcendência revela-se através dos "reflexos gerais de natureza econômica, política, social ou jurídica" apresentados pela causa submetida ao TST, a quem compete regulamentar, em seu Regimento Interno, o processamento da causa, assegurando-se a sessão pública, o direito à sustentação oral e a fundamentação da decisão.

Nos termos do Projeto de Lei $n^{\circ}$ 3.267/00, que introduziu o art. 896-A à CLT, a transcendência jurídica poderia ser entendida como "o desrespeito patente aos direitos humanos fundamentais ou aos interesses coletivos indisponíveis, com comprometimento da

cle\%3D0\%26p_p_state\%3Dnormal\%26p_p_mode\%3Dview\%26p_p_col_id\%3Dcolumn-

3\%26p_p_col_count\%3D5. Acesso em 29 de dezembro de 2013.

56 "Art.896-A - O Tribunal Superior do Trabalho, no recurso de revista, examinará previamente se a causa oferece transcendência com relação aos reflexos gerais de natureza econômica, política, social ou jurídica."

${ }^{57}$ A esse respeito, explica Sérgio Pinto Martins: "Transcendente é um adjetivo com o significado de muito elevado; sublime; superior; agudo; perspicaz; metafísico; que excede ou ultrapassa os limites ordinários; que dimana imediatamente da razão. A transcendência pode acabar envolvendo um critério subjetivo do julgador. Transcendência significa relevância. É semelhante à arguição de relevância para o STF." (cf. Direito processual do trabalho, pp. 416). 
segurança e estabilidade das relações jurídicas" $"$. A transcendência política deveria ser definida como "o desrespeito notório ao princípio federativo ou à harmonia dos Poderes constituídos" "59. Já a transcendência social, por sua vez, seria "a existência de situação extraordinária de discriminação, de comprometimento do mercado de trabalho ou de perturbação notável à harmonia entre capital e trabalho" ${ }^{" 60}$. E, por fim, a transcendência econômica, tida como "a ressonância de vulto da causa em relação a entidade de direito público ou economia mista, ou a grave repercussão da questão na política econômica nacional, no segmento produtivo ou no desenvolvimento regular da atividade empresarial" ${ }^{\prime 61}$.

Como se verá a seguir, o instituto da Repercussão Geral também guarda bastante semelhança com o critério da transcendência adotado pela Justiça do Trabalho, principalmente por se tratarem, ambos, de institutos destinados à tentativa de contenção do avanço do volume de processos submetidos ao julgamento das Instâncias Extraordinárias.

Nesse sentido, leciona SÉRgio PINTO MARTins que a transcendência pode ser entendida

"no sentido de dar preferência a recursos de revista que envolvam reflexos gerais de natureza econômica, política, social ou jurídica, que teriam mais importância do que outros aspectos, principalmente para o governo. Isso ocorreria justamente porque tais assuntos seriam mais importantes do que outros, daí se falar em transcendência. O julgamento terá de ser público, sendo vedado o julgamento secreto, como ocorria quando havia arguição de relevância. A transcendência deve ser observada nos recursos apresentados a partir da regulamentação da matéria no Regimento Interno do TST." ${ }^{2}$

Vale notar, contudo, que a transcendência do recurso de revista não tem sido amplamente aplicada pelo Tribunal Superior do Trabalho. Instituída pela Medida Provisória

\footnotetext{
${ }^{58}$ Nesse sentido, podemos citar, à luz dos ensinamentos de Ives Gandra da Silva Martins Filho (op. cit.), (i) os recursos oriundos de ações civis públicas, nas quais se discutem direitos difusos e coletivos; (ii) processos em que o sindicato atue como substituto processual da categoria de trabalhadores; (iii) causas que versem sobre norma de Direito Natural (direito à vida, à liberdade, à igualdade perante a lei, etc.); e (iv) processos em que um TRT resista a albergar a jurisprudência pacificada do TST ou do STF.

${ }^{59}$ Como exemplos de causas de notável transcendência política, é possível destacar (i) guerra fiscal dos Estados em torno do ICMS, o que pode provocar a migração de empresas e/ou trabalhadores em busca de maior lucratividade ou remuneração; e (ii) processos que envolvam entes públicos, principalmente quando a execução se dá através de precatórios, em que medidas relativas ao sequestro de contas podem criar instabilidade entre o TRT e o governo local.

${ }^{60}$ Alguns exemplos de transcendência social podem ser encontrados em processos que discutam a adoção, no âmbito de uma empresa, de normas ou procedimentos internos discriminatórios, restritivos à contratação ou estimuladores de conflituosidade entre patrões e empregados.

${ }^{61}$ Além de estar ligada, diretamente, ao valor atribuído à causa, a transcendência econômica também pode ser percebida pela importância da causa para a empresa pública ou privada, ou seja, se a demanda é capaz de repercutir no regular desempenho de sua atividade produtiva, por exemplo.

${ }^{62}$ Cf. op.cit., pp. $416-417$.
} 
$\mathrm{n}^{\circ}$ 2.226/01, cuja constitucionalidade é questionada através da ADI $\mathrm{n}^{\circ} 2.527$, ainda pendente de julgamento de mérito, não houve, até o presente momento, a adequada regulamentação do instituto, razão pela qual sua aplicação prática ainda não encontra espaço para se desenvolver. 


\section{A REPERCUSSÃO GERAL DA QUESTÃO CONSTITUCIONAL}

Com vistas a diminuir o volume de trabalho submetido ao Supremo Tribunal Federal, amenizar a crise do Judiciário e selecionar as demandas verdadeiramente relevantes, a Emenda Constitucional no 45/2004 instituiu um novo filtro recursal: a Repercussão Geral da questão constitucional ${ }^{63}$.

Inspirada na extinta arguição de relevância e em institutos internacionalmente bem-sucedidos, a Repercussão Geral visa a selecionar os processos em que sejam discutidas questões constitucionais relevantes, do ponto de vista econômico, político, social e jurídico, e cujos efeitos repercutam para além dos limites da demanda, de modo que apenas estes poderão ser submetidos ao julgamento do Supremo Tribunal Federal ${ }^{64}$.

Nas palavras de Rodolfo de CAMARgo MANCuso,

"Um tema jurídico, uma vez prequestionado e submetido ao STF por meio de recurso extraordinário, apresentará Repercussão Geral quando sua resolução for além do interesse direto e imediato das partes, assim transcendendo-o, para alcançar, em maior ou menor dimensão ou intensidade, um expressivo segmento da coletividade (v.g., oferta gratuita de medicação, pela rede pública de saúde, aos HIV soro-positivos pobres); ou um dado setor produtivo (v.g., proibição de exportação de carne por suspeita de febre aftosa); ou mesmo, a inteira coletividade (v.g., comercialização de produto geneticamente modificado; interrupção da gravidez em caso de feto anencéfalo)". ${ }^{65}$

Criada pela Emenda Constitucional $n^{\circ} 45 / 2004$, que introduziu o novo parágrafo $3^{\circ}$ do art. 102 da Constituição Federal, posteriormente regulamentado pela Lei $\mathrm{n}^{\circ}$ 11.418/2006, que criou os novos artigos 543-A e 543-B do Código de Processo Civil, a Repercussão Geral deve ser entendida como a relevância da questão constitucional tratada em um caso concreto, cujos efeitos transcendem os interesses subjetivos das partes litigantes.

Trata-se, portanto, como também se verá, de um conceito jurídico propositalmente indeterminado, com vistas a conceder ao aplicador do Direito uma maior margem de

\footnotetext{
${ }^{63}$ Nos dizeres de Araken de Assis, "é flagrante que o instituto da Repercussão Geral filia-se à corrente do pragmatismo judiciário - a fonte de inspiração depõe neste sentido - e visa ao aprimoramento da atividade judicante do STF como corte constitucional". Cf. op. cit., p. 709.

${ }^{64}$ Inúmeras críticas foram inicialmente feitas ao novo filtro recursal criado; ganharam especial destaque aquelas que afirmavam que toda questão constitucional é relevante e transcendente, de modo que nenhuma delas poderia ser afastada da apreciação do Supremo Tribunal Federal. No entanto, ROGÉRIO IVES BRAGHITTONI bem elucidou a controvérsia, dizendo que "se é verdade que todo dispositivo constitucional é 'relevante' e tem 'Repercussão Geral', não significa que toda causa em que se discuta algum dispositivo constitucional também o seja". (Cf. Recurso Extraordinário. Uma análise do acesso ao Supremo Tribunal Federal, p. 77).

${ }^{65}$ Cf. op. cit., pp. 211 e 212.
} 
liberdade em sua interpretação casuística, de modo a permitir uma célere e constante adaptação da norma jurídica positivada às novas realidades fáticas e sociais que se apresentem.

É, assim, mais um requisito de admissibilidade ${ }^{66}$ imposto ao conhecimento dos recursos extraordinários, cuja avaliação, segundo parte da doutrina, pode assumir um cunho mais político do que jurisdicional.

Na prática, o instituto da Repercussão Geral tem se revelado bastante eficiente. Dados estatísticos, que serão analisados em detalhe a seguir, revelam que, desde a sua criação até os dias de hoje, houve uma significativa redução de 64\% (sessenta e quatro por cento) no número de recursos distribuídos aos Ministros da Corte.

Isso significa que quase 160.000 (cento e sessenta mil) processos em trâmite na Instância Ordinária foram impactados pelas decisões proferidas em matéria de Repercussão Geral e impedidos de alcançar o STF.

Assim, é possível dizer, como se verá, que o instituto de Repercussão Geral tem logrado atingir seu objetivo, ou seja, tem reduzido o volume de demandas submetidas à apreciação do Supremo Tribunal Federal, de tal modo que possa ele debruçar-se apenas sobre as questões verdadeiramente importantes e significativas à nação.

\section{$\underline{3.1 \text { Os aspectos legais }}$}

\subsubsection{A Emenda Constitucional $n^{\circ} 45$ e o parágrafo $3^{\circ}$ do art. 102 da Constituição} Federal de 1988

A Emenda Constitucional $n^{\circ}$ 45, promulgada em 08 de dezembro de 2004, realizou a chamada Reforma do Judiciário, alterando, em especial, os dispositivos constitucionais relacionados com a organização e a atividade jurisdicional brasileira.

Imbuída de um espírito reformista e transformador, a Emenda Constitucional $\mathrm{n}^{\circ}$ 45 buscou aprimorar a qualidade da prestação jurisdicional brasileira e amenizar a discrepância então existente entre o nosso direito posto e a realidade das transformações e avanços sociais.

De acordo com tal pensamento, criou-se o novo parágrafo $3^{\circ}$ do artigo 102 da Constituição Federal, determinando que, "no recurso extraordinário o recorrente deverá

\footnotetext{
${ }^{66}$ Sua existência integra o juízo de admissibilidade do recurso extraordinário, configurando "uma condição específica do cabimento desse remédio" (Cf. Araken de Assis, op. cit., p. 712).
} 
demonstrar a Repercussão Geral das questões constitucionais discutidas no caso, nos termos da lei, a fim de que o Tribunal examine a admissão do recurso, somente podendo recusá-lo pela manifestação de dois terços de seus membros".

Vemos que o texto da Magna Carta deixou ao arbítrio do legislador infraconstitucional a tarefa de melhor delimitar o conceito, a abrangência e a aplicação prática do novo instituto.

São necessários os votos de dois terços dos Ministros do Supremo Tribunal Federal para reconhecer a inexistência do requisito da Repercussão Geral e, assim, inadmitir o recurso extraordinário - quórum idêntico ao exigido, por exemplo, para a edição, revisão e cancelamento de súmulas vinculantes, nos termos do caput do art. 103-A, da Constituição Federal $^{67}$.

Tal exigência fez com que o novo filtro recursal fosse utilizado com cautela, evitando arbitrariedades na definição concreta do conceito da Repercussão Geral. Nesse sentido, destaca José Manoel de Arruda Alvim Neto que

"a recusa do recurso extraordinário, porque ausente a Repercussão Geral, pela elevada maioria de dois terços é saudável, porquanto procura que esteja subjacente a essa recusa um alto grau de certeza e segurança, compensatórias diga-se assim - da circunstância de a Repercussão Geral constituir-se num conceito vago, propiciando menor certeza e menos segurança". ${ }^{8}$

Nesse mesmo sentido, ressaltando que o elevado quórum reflete a intenção do legislador constituinte de manter, como regra, o cabimento do recurso extraordinário, são as palavras de BRUNO DANTAS:

"No caso da Repercussão Geral, o fato é que estamos diante de um conceito jurídico indeterminado que encerra restrição a recurso de estatura constitucional. Dada sua indeterminação conceitual - que necessariamente envolve um elevado teor de subjetividade na aplicação in concreto -, o elevado quorum serve como 'elemento compensador' da natural redução da previsibilidade, especialmente se cotejado com um conceito minucioso.

Dessarte, ao exigir quorum qualificadíssimo, o constituinte derivado acenou à sociedade que a regra continuar a ser o cabimento do RE. A exceção é a inadmissibilidade, e ela só ocorrerá, nesse caso, quando estiver claro, para ao

\footnotetext{
67 “Art. 103-A. O Supremo Tribunal Federal poderá, de ofício ou por provocação, mediante decisão de dois terços dos seus membros, após reiteradas decisões sobre matéria constitucional, aprovar súmula que, a partir de sua publicação na imprensa oficial, terá efeito vinculante em relação aos demais órgãos do Poder Judiciário e à administração pública direta e indireta, nas esferas federal, estadual e municipal, bem como proceder à sua revisão ou cancelamento, na forma estabelecida em lei."

${ }^{68}$ Cf. op. cit., p. 65.
} 
menos oito ministros, que a questão constitucional em debate tem pó pano de fundo exclusivamente a irresignação do recorrente com o resultado desfavorável, sem qualquer perspectiva de o julgamento ali pronunciado servir para além dos limites estritamente subjetivos das duas partes." 99

Vale notar, por fim, que o novel parágrafo $3^{\circ}$ do artigo 102 da Constituição Federal teve sua constitucionalidade questionada, através da ADIn $n^{\circ} 4.149$, ajuizada pelo Instituto Brasileiro de Defesa dos Lojistas de Shopping - IDELOS. Esta demanda, contudo, não chegou a ter seu mérito apreciado, em virtude do reconhecimento da ilegitimidade $a d$ causam da autora ${ }^{70}$.

3.1.2 A Lei $\mathrm{n}^{\mathrm{o}}$ 11.418/2006, o artigo 543-A do Código de Processo Civil e as Emendas ao Regimento Interno do Supremo Tribunal Federal

A Lei no 11.418 foi publicada em 19 de dezembro de 2006, ”com a aprovação de quatro emendas de redação, sugeridas pelo deputado Odair Cunha, relator do Projeto $n^{o}$ 6.648/2006 na Câmara",71, e veio atender às exigências constitucionais de regulamentação do novo instituto da Repercussão Geral.

Assim, adicionou-se ao Código de Processo Civil ${ }^{72}$ o artigo 543-A, que regulamenta, de forma mais precisa e com um enfoque mais prático, a Repercussão Geral da questão constitucional:

“Art. 543-A. O Supremo Tribunal Federal, em decisão irrecorrível, não conhecerá do recurso extraordinário, quando a questão constitucional nele versada não oferecer Repercussão Geral, nos termos deste artigo.

$\S 1^{\circ}$ Para efeito da Repercussão Geral, será considerada a existência, ou não, de questões relevantes do ponto de vista econômico, político, social ou jurídico, que ultrapassem os interesses subjetivos da causa.

$\S 2^{\circ} \mathrm{O}$ recorrente deverá demonstrar, em preliminar do recurso, para apreciação exclusiva do Supremo Tribunal Federal, a existência da Repercussão Geral.

\footnotetext{
${ }^{69}$ Cf. op. cit., p. 233.

${ }^{70}$ Sobre o tema: BRUNO DANTAS, op. cit., p. 227.

${ }^{71}$ Cf. J.R.C. TUCCI, op. cit., p. 25.

72 Em pertinente crítica à técnica legislativa adotada, pontua Bruno Dantas: "Em nosso entender, estava absolutamente correta a decisão inicial de regulamentar o instituto da Repercussão Geral por meio de legislação esparsa, tal qual constante do projeto original elaborado pela CME do Judiciário. Talvez pudesse ter sido cogitada a possibilidade de se alterar a Lei 8.038, de 1990, que já trata dos recursos da competência do STF e STJ, mas a ideia de alterar o Código de Processo Civil se revela totalmente inadequada. (...) O fato é que o instituto da Repercussão Geral, por ser de índole constitucional, e aplicável à Corte que, além do contencioso civil, também é responsável por questões que tramitaram nas justiças penal, trabalhista, eleitoral e militar, acabou sendo mal acomodado no Código de Processo Civil." (Cf. op. cit., p. 290).
} 
$\S 3^{\circ}$ Haverá Repercussão Geral sempre que o recurso impugnar decisão contrária a súmula ou jurisprudência dominante do Tribunal.

$\S 4^{\circ}$ Se a Turma decidir pela existência da Repercussão Geral por, no mínimo, 4 (quatro) votos, ficará dispensada a remessa do recurso ao Plenário.

$\S 5^{\circ}$ Negada a existência da Repercussão Geral, a decisão valerá para todos os recursos sobre matéria idêntica, que serão indeferidos liminarmente, salvo revisão da tese, tudo nos termos do Regimento Interno do Supremo Tribunal Federal.

$\S 6^{\circ}$ O Relator poderá admitir, na análise da Repercussão Geral, a manifestação de terceiros, subscrita por procurador habilitado, nos termos do Regimento Interno do Supremo Tribunal Federal.

$\S 7^{\circ}$ A Súmula da decisão sobre a Repercussão Geral constará de ata, que será publicada no Diário Oficial e valerá como acórdão."

No caput do dispositivo acima transcrito, é possível antever a natureza do instituto da Repercussão Geral, como novo requisito intrínseco de admissibilidade do recurso extraordinário $^{73}$.

O parágrafo $1^{\circ}$ prescreve que estará presente a Repercussão Geral sempre que o recurso extraordinário versar sobre matéria relevante do ponto de vista econômico, político, social ou jurídico ${ }^{74}$, exigindo, ainda, para a sua efetiva caracterização, que o interesse na solução do litígio ultrapasse os interesses subjetivos das partes.

O parágrafo $2^{\circ}$ dispõe que a presença da Repercussão Geral deve ser demonstrada em preliminar do recurso extraordinário, submetida à apreciação exclusiva do Supremo Tribunal Federal, mediante ato colegiado da Turma ou do Plenário, dado o seu caráter de prejudicialidade. Trata-se de uma regularidade formal, cuja inobservância implica na inadmissão do recurso.

Já o parágrafo $3^{\circ}$ estabelece uma hipótese de presunção da existência de Repercussão Geral, que revela a preocupação do legislador infraconstitucional com a segurança jurídica e com a função uniformizadora do recurso extraordinário: será relevante o recurso extraordinário sempre que impugnada decisão contrária à súmula ou jurisprudência dominante do Supremo Tribunal Federal.

O parágrafo $4^{\circ}$, por sua vez, determina que, se quatro Ministros decidirem pela presença da Repercussão Geral, a análise da admissibilidade recursal pelo Plenário do Supremo Tribunal Federal estará dispensada.

\footnotetext{
${ }^{73}$ A natureza jurídica do novel instituto será abordada, com maiores detalhes, no item 5.2.2 adiante.

${ }^{74}$ Para José Rogério Cruz e Tucci, "nada obsta, à evidência, que o objeto do Recurso Extraordinário encerre, a um só tempo, relevância política e social, ou mesmo, social e econômica, mas sempre de índole constitucional” (Cf. Anotações sobre a Repercussão Geral como pressuposto de admissibilidade do Recurso Extraordinário (Lei $n^{o}$ 11.418/2006), p. 26).
} 
Esse dispositivo revela o intuito do legislador infraconstitucional de desburocratizar o instituto e evitar o risco de sobrecarga do Plenário do STF. Trata-se de regra flexibilizadora, que se justifica pelo fato de que, ainda que os demais Ministros decidam pela inexistência da Repercussão Geral, o quórum exigido pelo art. 102, III, da Constituição Federal de 1988 para a rejeição do recurso não será atendido.

O parágrafo $5^{\circ}$ reforça a eficácia futura e vinculante da decisão do Supremo Tribunal Federal que entender pela inexistência a Repercussão Geral, o que permite que milhares de recursos que versem sobre matéria idêntica sejam liminarmente indeferidos.

Vale ressaltar, ainda, que o legislador preservou a atuação legiferante do Supremo Tribunal Federal, ao atribuir a seu Regimento Interno a faculdade de estabelecer novas regras acerca da tramitação dos recursos repetitivos, como se verá mais adiante.

O parágrafo $6^{\circ}$ permite a intervenção de terceiros que poderiam, de alguma forma, ser prejudicados com a inadmissibilidade de determinado recurso extraordinário, em razão da inexistência da Repercussão Geral.

Como se verá com maiores detalhes a seguir, a intervenção de terceiros, neste caso, deve se dar sob a modalidade de amicus curiae. Essa forma de intervenção permite que terceiros interessados integrem a demanda, com o intuito de contribuir para a discussão das teses jurídicas nela ventiladas ${ }^{75}$. Tal previsão representa uma forma de legitimar as decisões do Supremo Tribunal Federal que projetem sua eficácia sobre um número considerável de jurisdicionados ${ }^{76}$.

Por fim, o parágrafo $7^{\circ}$ determina que a decisão do Plenário do STF sobre a Repercussão Geral será devidamente publicada e terá efeitos próprios de acórdão, em observância aos princípios da publicidade e da devida motivação das decisões judiciais. Nos

\footnotetext{
${ }^{75}$ Trata-se de uma ferramenta adicional de defesa, que proporciona representatividade à sociedade em assuntos de eminente relevância. É mais comumente utilizada, na prática forense brasileira, em processos objetivos, versando sobre controvérsias baseadas em leis em tese. Segundo Fredie Souza Didier Júnior, é um perito em matéria de direito, um auxiliar do juízo; para o próprio Supremo Tribunal Federall Tribunal, é instrumento apto a democratizar a discussão sobre relevante matéria constitucional, pois visa ampliar o debate das questões suscitadas. Está previsto pela Lei ${ }^{\circ}$ 6.385/1976 (art. 31), Lei n ${ }^{\circ} 8.884 / 1994$ (art. 89), Lei no 9.868/1999 (art. $7^{\circ}$, § $2^{\circ}$ ), Lei $n^{\circ} 9.882 / 1999$ (art. $6^{\circ}, \S 1^{\circ}$ ), Lei $n^{\circ} 10.259 / 2001$, Lei $n^{\circ} 11.417 / 2006$ (art. $2^{\circ}, \S 2^{\circ}$ ), além da previsão contida no Código de Processo Civil, em seu artigo 482, $\S 3^{\circ}$ e no Regimento Interno do STF, em seus artigos $131, \S 3^{\circ}$ e $323, \S 2^{\circ}$, entre outros diplomas legais. No entanto, há quem discorde dessa posição, por não entender presente a imparcialidade característica do amicus curiae, uma vez que o terceiro interveniente, aqui, participa bastante ativamente do procedimento e deve demonstrar um interesse direito na admissão do recurso.

${ }^{76}$ Segundo Cássio Scarpinela Bueno, "a única forma de legitimar as decisões do Supremo Tribunal Federal, sobretudo daquelas que projetam eficácia sobre um número considerável de jurisdicionados é reconhecer que ele deve, previamente, dar ouvidos a pessoas ou entidades representativas da sociedade civil -e, até mesmo, a pessoas de direito público que desempenhem, de alguma forma, esse mesmo papel, capturando os próprios valores dispersos do Estado, suas diversas opiniões e visões de políticas públicas a serem perseguidas também em juízo -, verificando em que medida estão configurados adequadamente os interesses, os direitos e os valores em jogo de lado a lado".
} 
dizeres de Rodolfo De CAMARgo MAncuso, “operará importante efeito dissuasório, desestimulando a interposição de recursos extraordinários versando sobre temas que, ao ver do STF, não projetam Repercussão Geral"77.

Vale mencionar, ademais, o novel artigo $543-\mathrm{B}^{78}$ do Código de Processo Civil, também criado pela Lei $n^{\circ} 11.418 / 2006$, que disciplina a análise da Repercussão Geral em recursos repetitivos.

Dispõe o referido artigo que, havendo multiplicidade de recursos repetitivos, fundados em idêntica controvérsia, deverá o Tribunal de origem selecionar um ou mais, que servirão como paradigma da matéria neles ventilada, e encaminhá-los ao Supremo Tribunal Federal, para a apreciação da Repercussão Geral. Todos os demais ficarão sobrestados na Instância a quo, até o pronunciamento definitivo do Juízo ad quem.

Entendendo o Supremo Tribunal Federal pela inexistência de Repercussão Geral, no julgamento do recurso paradigma, todos os demais recursos idênticos, então sobrestados, serão automaticamente inadmitidos.

Devemos ressaltar, aqui, que a inadmissibilidade dos recursos sobrestados será decretada através de decisão interlocutória, proferida pelo Presidente ou Vice-Presidente do Tribunal de origem, e, como tal, passível de recurso de agravo de instrumento, nos termos do artigo 544 do Código de Processo Civil ${ }^{79}$.

Julgado o mérito do recurso paradigma, os Tribunais a quo poderão se retratar, na hipótese de provimento do recurso paradigma, reformando, assim, o acórdão recorrido. Tal retratação, contudo, é mera faculdade das Instâncias Ordinárias, que poderão, a despeito do

\footnotetext{
${ }^{77}$ Cf. op. cit., p. 208.

78 “Art. 543-B. Quando houver multiplicidade de recursos com fundamento em idêntica controvérsia, a análise da Repercussão Geral será processada nos termos do Regimento Interno do Supremo Tribunal Federal, observado o disposto neste artigo.

$\S 1^{\circ}$ Caberá ao Tribunal de origem selecionar um ou mais recursos representativos da controvérsia e encaminhálos ao Supremo Tribunal Federal, sobrestando os demais até o pronunciamento definitivo da Corte.

$\S 2^{\underline{0}}$ Negada a existência de Repercussão Geral, os recursos sobrestados considerar-se-ão automaticamente não admitidos.

$\S 3^{\circ}$ Julgado o mérito do recurso extraordinário, os recursos sobrestados serão apreciados pelos Tribunais, Turmas de Uniformização ou Turmas Recursais, que poderão declará-los prejudicados ou retratar-se.

$\S 4^{0}$ Mantida a decisão e admitido o recurso, poderá o Supremo Tribunal Federal, nos termos do Regimento Interno, cassar ou reformar, liminarmente, o acórdão contrário à orientação firmada.

$\S 5^{\circ}$ O Regimento Interno do Supremo Tribunal Federal disporá sobre as atribuições dos Ministros, das Turmas e de outros órgãos, na análise da Repercussão Geral".

79 "Art. 544. Não admitido o recurso extraordinário ou o recurso especial, caberá agravo de instrumento, no prazo de 10 (dez) dias, para o Supremo Tribunal Federal ou para o Superior Tribunal de Justiça, conforme o caso". No entanto, há que sustente que a discussão a ser instaurada pelo recurso de Agravo de Instrumento deverá se limitar à ausência da "repetitividade" tida no caso concreto. Para maiores detalhes acerca da recorribilidade da decisão proferida pelo Presidente ou Vice-Presidente do Tribunal Estadual, ver item 5.3.2. (b), a seguir.
} 
quanto decidido pelo Supremo Tribunal Federal, manter íntegra sua decisão e determinar a remessa dos recursos sobrestados à análise do STF.

Nesses casos, poderá o STF cassar ou reformar, liminarmente, o acórdão recorrido ${ }^{80}$

A Lei $n^{\mathbf{0}}$ 11.418/2006 determina, por fim, em seu artigo $3^{\mathbf{0}}$, que caberá ao Supremo Tribunal Federal, em seu Regimento Interno, estabelecer as normas necessárias à execução do disposto na lei.

Nesse sentido, foram editadas diversas Emendas, que alteraram o Regimento Interno do STF, com o intuito de viabilizar a aplicação prática do novo filtro recursal, regulamentando o processamento da Repercussão Geral ${ }^{81}$.

Deve-se ressaltar que, somente a partir de 30 de abril de 2007, data da publicação da primeira de tais Emendas ao RISTF (n 21/2007), o Supremo Tribunal Federal passou a exigir, definitivamente, a demonstração da Repercussão Geral como requisito intrínseco de admissibilidade de recursos extraordinários. Entendeu-se que só nesse momento o novo instituto restou suficientemente regulamentado, podendo, então, ser considerado obrigatório ${ }^{82}$.

Seguiram-se, então, outras reformas ao Regimento Interno do Supremo Tribunal Federal - RISTF, através das Emendas Regimentais nº 22/2007, 23/2008, 24/2008, 27/2008, 31/2009, 41/2010, 42/2010 e 47/2012, e da Portaria n ${ }^{\mathrm{o}} 138 / 2009$. $^{83}$

Os artigos 323 e seguintes do RISTF disciplinam o procedimento interno adotado pelo Supremo Tribunal Federal para a apreciação e julgamento da Repercussão Geral da questão constitucional.

Merece destaque especial - além da previsão de hipótese de presunção relativa da existência de Repercussão Geral, nos termos do art. 324, parágrafo $1^{\circ}$, que será abordada com maiores detalhes a seguir - a atribuição de poderes e novas competências ao Presidente do Supremo Tribunal Federal, para exercer o juízo de admissibilidade dos recursos antes mesmo de sua distribuição.

\footnotetext{
${ }^{80}$ Disposição muito semelhante pode ser encontrada no artigo 557, § $1^{\circ}$-A, do Código de Processo Civil: "Art. 557. O relator negará seguimento a recurso manifestamente inadmissível, improcedente, prejudicado ou em confronto com súmula ou com jurisprudência dominante do respectivo tribunal, do Supremo Tribunal Federal, ou de Tribunal Superior. $\S 1^{\circ}$-A Se a decisão recorrida estiver em manifesto confronto com súmula ou com jurisprudência dominante do Supremo Tribunal Federal, ou de Tribunal Superior, o relator poderá dar provimento ao recurso".

${ }^{81}$ Cf. Emendas Regimentais no 21/2007, no 22/2007, no 23/2008, no 24/2008, no 27/2008 e no 31/2009, além da Portaria $\mathrm{n}^{\mathbf{0}} 138$, de 23 de julho de 2009.

${ }^{82}$ Cf. QO-AI 664.567, Min. Sepúlveda Pertence.

83 Disponível, na íntegra, em http://www.stf.jus.br/arquivo/cms/legislacaoRegimentoInterno/anexo/RISTF_Dezembro_2013_versao_eletronic a.pdf. Acesso em 02 de janeiro de 2014.
} 
É o preconizam os artigos 13 , inciso $\mathrm{V}$, alínea $c^{84}$, e $323-\mathrm{A}^{85}$ do RISTF, ao delegarem ao Presidente poderes típicos dos Relatores, podendo, inclusive, submeter ao Plenário, por meio eletrônico, a confirmação de jurisprudência do STF, com a finalidade de aferir se a decisão recorrida, ao contrariá-la, reveste-se de Repercussão Geral e confirma a hipótese de presunção legalmente prevista.

A intenção de tais reformas, como se vê, é reduzir também a quantidade de recursos distribuídos aos Ministros, de modo a permitir que o Supremo Tribunal Federal possa seguir garantindo a unidade e inteireza do direito positivo brasileiro.

\subsection{Os aspectos teóricos}

\subsubsection{O conceito jurídico indeterminado de "Repercussão Geral"}

Como visto, considera-se, para efeito de Repercussão Geral, a existência de questões relevantes do ponto de vista econômico, político, social ou jurídico, que ultrapassem os interesses subjetivos da causa ${ }^{86}$.

Trata-se, portanto, de conceito jurídico indeterminado, vago ${ }^{87-88}$ e elástico ${ }^{89}$, por opção do próprio legislador, que buscou fugir do risco de engessamento do sistema ao tentar delimitar e definir as inúmeras hipóteses concretas que poderiam surgir, ao longo do tempo,

\footnotetext{
84 “Art. 13. São atribuições do Presidente:
}

$\mathrm{V}$ - despachar:

c) como Relator, nos termos dos arts. 544, $\S 3^{\circ}$, e 557 do Código de Processo Civil, até eventual distribuição, os agravos de instrumento, recursos extraordinários e petições ineptos ou de outro modo manifestamente inadmissíveis, inclusive por incompetência, intempestividade, deserção, prejuízo ou ausência de preliminar formal e fundamentada de Repercussão Geral, bem como aqueles cuja matéria seja destituída de Repercussão Geral, conforme jurisprudência do Tribunal."

85 "Art. 323-A. O julgamento de mérito de questões com Repercussão Geral, nos casos de reafirmação de jurisprudência dominante da Corte, também poderá ser realizado por meio eletrônico."

${ }_{86} \mathrm{O}$ legislador preferiu o termo repercussão a simples relevância justamente para afastar a crítica, inevitável, dando conta de que todas as questões constitucionais são relevantes, ainda que delas não decorram efeitos para além dos sujeitos da demanda.

${ }^{87}$ Conceito este que, no entender de Arruda Alvim, configura um instrumento idôneo para assegurar a flexibilidade do direito, já que, por sua própria natureza "abre margem a uma interpretação afeiçoada às peculiaridades do caso concreto e, pois, à individualização de todas as hipóteses à luz da ratio legis." (Cf. op. cit., p. 12).

${ }^{88} \mathrm{Na}$ ótica de Bruno Dantas, o conceito de Repercussão Geral consiste em "um misto de conceito descritivo indeterminado e conceito normativo indeterminado, pois, embora a representação da palavra repercussão possa ser percebida pelos sentidos, independendo, em princípio, de preenchimento valorativo para sua concretização, o mesmo não ocorre com a palavra geral, de modo que resuta inegável que a definição do caráter geral pode dar ensejo a questionamentos no plano do halo conceitual." (Cf. op. cit., p. 248).

${ }_{89}$ Nas palavras de Humberto Theodoro Júnior: "É certo que, ao exigir a Repercussão Geral da questão enfrentada na fundamentação do extraordinário, nos termos do $\$ 3^{\circ}$ do art. 102 da Constituição, o legislador faz uso de conceitos elásticos, que permitem ao interprete e aplicador da norma uma atividade construtiva ou concretizadora, que vai além da simples e automática subsunção do caso concreto ao preceito literal e exato da regra." (Cf. op. cit., p. 105). 
com a aplicação prática do instituto da Repercussão Geral ${ }^{90}$. Nas palavras de ARRUDA AlviM, proferidas antes da edição da Lei n ${ }^{\circ} 11.419 / 2006$ :

"A utilização da expressão Repercussão Geral, ainda que venha a ser objeto de disciplina por lei, está, em si mesma, carregado intencionalmente de vaguidade. A regulamentação pela lei ordinária deverá disciplinar o instituto, mas não deverá acabar, propriamente, por definir inteiramente, ou não, o que Repercussão Geral, dado que, se o fizesse, sem deixar espaço para o STF, certamente acabaria por engessar o sentido do Texto Constitucional." 91 .

A imprecisão do conceito de Repercussão Geral $^{92}$ permite que o ordenamento jurídico se desenvolva e se mantenha permanentemente atualizado, adaptando-se de forma mais eficaz e rápida às variadas e constantes mudanças da sociedade atual, dispensando, assim, eventuais alterações legislativas ${ }^{93}$.

A ausência de um conceito exato e bem delimitado ${ }^{94}$ permite, portanto, que os textos normativos acompanhem, de perto, a complexidade das relações humanas e sociais ${ }^{95}$,

\footnotetext{
${ }^{90}$ Nesse sentido, destaca André de Albuquerque Cavalcanti Abbud que "os critérios fornecidos pelo legislador, no entanto, encerram-se nisto: a necessidade de relevância jurídica ou metajurídica da questão discutida no recurso, medida pelo impacto que produza em interesses que extravasem os dos litigantes no caso concreto. Aí concluiu seu trabalho o legislador ordinário, na determinação do que há de se entender por Repercussão Geral. Se mais não disse, é porque tal não lhe cumpria mesmo. De nada adiantaria criar uma cláusula geral, que carrega em si o propósito de conferir flexibilidade ao trabalho do intérprete, se a lei descesse a pormenores na tentativa de fixar o seu conteúdo, conduzindo o juiz novamente a engessadas possibilidades exegéticas." (Cf. op. cit., p. 297). Também, como bem alerta Ulisses Schwarz Viana: "Os preceitos legais imperfeitos - imprecisos e indeterminados - colocam a questão de que a norma não é capaz de abarcar e elencar todas as hipóteses e possibilidades do mundo fático, em que se insere a existência humana e a própria sociedade." (Cf. op. cit., p. 40).

${ }^{91}$ Cf. A EC n $n^{\circ} 45$ e o instituto da Repercussão Geral, pp. 73-74.

92 Nas palavras de Humberto Theodoro Júnior: "Só uma ciência exata pode conduzir a revelação de leis unívocas e invariáveis em sua compreensão. Leis de comportamento humano, destinadas à programação de atos futuros e hipotéticos, sob a carga de valores e variações fáticas nunca delimitáveis com precisão, não podem obviamente seguir critérios de lógica pura ou matemática. A lógica do direito é a do razoável, ou seja, a do raciocínio dialético ou tópico, inspirado nos valores e na técnica da argumentação, sempre à procura de um resultado justo, mais inspirado na flexibilidade dos princípios do que na rigidez das regras frias e exatas.

Nesse sentido, pode-se afirmar que todas as leis de direito são de certa forma dotadas de certa imprecisão, cujo grau pode variar, mas cuja presença nunca poderá ser evitada. O que varia é, pois, o volume da indeterminação, nunca a sua presença. Diante dessa natural e inevitável fluidez das normas jurídicas, a tarefa do intérprete e aplicador não será livre e discricionária, de forma alguma, pois estará sempre vinculada aos valores que inspiram e justificam a regra traçada pelo legislador." (Cf. op. cit., pp. 105-106).

93 Como observa Ulisses Schwarz Viana: "aquela expressão adotada no $\S 3^{\circ}$ do art. 102 da CF possui teleologicamente um espaço de aplicação aberto; tão aberto quanto o espectro infinito de situações sociais a serem submetidas ao direito e que terão de ser sopesadas, nos procedimentos estabelecidos para a verificação da existência ou não Repercussão Geral de questões constitucionais, pela função abrangente, pragmática e funcional da jurisdição constitucional no Supremo Tribunal Federal, como posto final de observação das repercussões das decisões jurídicas no sistema social." (Cf. op. cit., p. 42).

94 Há, contudo, tentativas de definição do conceito de Repercussão Geral, à luz de suas características e peculiaridades. Nesse sentido, Bruno Dantas afirma que Repercussão Geral "é o pressuposto especial de cabimento do recurso extraordinário, estabelecido por comando constitucional, que impõe que o juízo de admissibilidade do recurso leve em consideração o impacto indireto que eventual solução das questões constitucionais em discussão terá na coletividade, de modo que se lho terá por presente apenas no caso de a
} 
além de restaurar a valorização das demais fontes do Direito, como formas de complementar e suprir as lacunas de cada caso concreto ${ }^{96}$.

Além disso, não raro a ofensa a um mesmo dispositivo constitucional pode se apresentar de diferentes formas, assumindo diversos relevos e proporções em cada caso concreto posto a exame pelo Supremo Tribunal Federal ${ }^{97}$. Em outras palavras, a violação a uma mesma norma constitucional pode ser vista sob diferentes enfoques, o que esvazia a utilidade de uma ideia de elaboração de rol legal e taxativo de hipóteses de presença - ou ausência - de Repercussão Geral.

Ademais, a vagueza do conceito de Repercussão Geral da questão constitucional atende à necessidade de flexibilização do requisito de admissibilidade do recurso extraordinário à luz de outros critérios, como o ineditismo da matéria discutida, a

decisão de mérito emergente do recurso ostentar a qualidade fazer com que parcela representativa de um determinado grupo de pessoas experimente, indiretamente, sua influência, considerados os legítimos interesses sociais extraídos do sistema normativo e da conjuntura política, econômica e social reinante num dado momento histórico." (Cf. op. cit., p. 260).

95 "Com os valores, que são ideias indefiníveis (aporias e, portanto, inverbalizáveis), o que ocorre é que devem ser indicados por conceitos vagos; não são nem devem ser propriamente conceituados, mas devem ser apenas referidos, pois é intensa a interação entre eles e a realidade paralela, a que se reportam.

(...) A utilização de conceitos vagos sabidamente diminui a margem de segurança e certeza jurídicas entendidas estas como uma ambicionada e pretendida previsibilidade de resultado, especialmente previsibilidade a partir do texto normativo -, porque isso não é prodigamente ofertado por esse tipo de norma. Mas é preciso ter presente que a opção do legislador por esta forma de comunicação carrega vantagens que sobrepujam a incerteza e a insegurança, mesmo porque - como no caso ora tratado - não se mostra operacional outra modalidade de disciplina normativa. Esta técnica normativa, inserida em setores significativos do direito, corresponde a uma tendência de nossos dias e já de há décadas. Esta técnica, certamente, viabiliza por parte do juiz o exercício de argumentação política. Se, por um lado, tal tipo de norma acarreta uma aplicação mais complexa, dela emergem resultados práticos - se bem entendida e aplicada - mais satisfatórios, do que ocorreria se a técnica de legislar, em relação ao objeto escolhido, fosse outra. E isto porque proporcionará a abrangência de todas as hipóteses, para cuja tutela jurídica foi idealizada. Deve a aplicação deste sistema provocar uma interação entre a norma e a realidade, esta última sendo 'operada' por aquela, e a realidade 'alimentará' a significação da norma." (Cf. A EC $n^{o} 45$ e o instituto da Repercussão Geral, pp. 74, 79-80).

${ }^{96}$ Nesse sentido, aponta Eduardo de Avelar Lamy: “A presença de conceitos vagos em textos legais se justifica em razão do aumento da complexidade social havido nos últimos séculos, que impossibilitou aos códigos cumprirem, sozinhos e detalhadamente, a missão de regular todas as ricas e diversificadas hipóteses geradoras de lide. Nesse desiderato, passaram a ser inseridos conceitos vagos nas legislações exatamente para que, por meio destes, as demais fontes do direito pudessem de forma operativamente eficaz, complementar o texto legal e possibilitar interpretar-se o sentido do conceito vago de forma adequada a cada caso concreto." (Cf. Repercussão Geral no recurso extraordinário: a volta da arguição de relevância?, p. 65).

97 “(...) existem causas - sempre se reconheceu isso - que são, pelos mais variados motivos, significativamente mais importantes para o conjunto da sociedade, ou para o próprio ordenamento jurídico, do que outras, em que a importância se restringiria às próprias partes. O reconhecimento dessa verdade quase óbvia é o primeiro passo para aceitar-se a ideia da existência de um filtro qualitativo para o acesso aos tribunais superiores - ou, ao menos, para o Tribunal Constitucional. Se existem causas que atingem um 'vasto número de pessoas', é perfeitamente admissível que se cogite que um determinado recurso só possa ser utilizado quando ocorra tal hipótese - a hipótese de que a causa seja desse tipo." (Cf. Acesso aos tribunais superiores: da argüição de relevância à Repercussão Geral, p. 46). 
possibilidade de alteração de um entendimento consolidado, o momento histórico-cultural vivido, entre outros ${ }^{98}$.

A tentativa de prever, de forma exauriente, todas as situações cotidianas concretas capazes de apresentar a transcendente relevância se mostra inadequada e fadada ao insucesso. Parece ilusória a existência de um dispositivo legal, com uma série interminável de incisos e subitens, descrevendo fatos minuciosamente detalhados, casuísticos e, certamente, insuficientes e incompletos, que acabariam por limitar a abrangência do próprio objeto definido ${ }^{99}$.

São incontáveis as hipóteses em que a Repercussão Geral da questão constitucional debatida pode se revelar presente, e a pretensão de prevê-las, todas, normativamente, acabaria por afastar da apreciação do Supremo Tribunal Federal algumas matérias que, com o decorrer do tempo, se mostrariam significativas e importantes para o País.

Nesse sentido, alerta EDUARDO TALAMINI:

"Cumpre ao Supremo Tribunal Federal, à luz das circunstâncias concretas vigentes no momento de sua deliberação, identificar os temas que se revestem de importância que transcenda o simples interesse das partes litigantes, sendo relevantes para a própria integridade do sistema jurídico-constitucional.

E essa aferição poderá variar de acordo com a conjuntura social, política e econômica. Não é de se descartar que uma questão que não tenha Repercussão Geral num dado contexto depois assuma esse atributo - e vice-versa. É inclusive por isso que a lei prevê expressamente a possibilidade de o Plenário rever o seu entendimento anterior acerca do assunto.",100

Caberá, portanto, ao jurista aplicador do Direito - em ato jurisdicional, dotado de certo viés político ${ }^{101}$ - preencher, casuisticamente, as lacunas que se lhe apresentarem, a partir

\footnotetext{
${ }^{98}$ Nesse sentido, a respeito das propostas de Emenda Constitucional para a instituição de novo requisito de admissibilidade aos recursos especiais: Relevância da questão federal como filtro de admissibilidade do recurso especial: análise das propostas de emenda constitucional n. 209/2012 e n. 17/2013, p. 5.

${ }^{99}$ Conforme leciona Arruda Alvim: 'É o que se passa com a 'definição' do que repercute geralmente, realidade esta que, aprioristicamente, se tem por indefinível (ou, ao menos, utilmente definível), de uma só vez, em termos propriamente completos, o que equivaleria a uma série infindável de incisos, exageradamente casuísticos e minuciosos, e, por fim, o que é mais grave, inevitavelmente incompletos, e, portanto, indesejavelmente limitadores do próprio objeto definido. O que se passa com tal noção é que ela deve ser objeto de decantação permanente, de que resultará, com o tempo, mosaico rico e variegado de matizes." (Cf. A EC no 45 e o instituto da Repercussão Geral, p. 74).

${ }^{100}$ Cf. Repercussão Geral em recurso extraordinário: nota sobre sua regulamentação, p. 37.

${ }^{101}$ Há quem entenda, como Arruda Alvim, que o reconhecimento da Repercussão Geral pelo STF não pode sequer ser entendido como prestação jurisdicional, tamanha a carga política envolvida em tal julgamento: " $O$ reconhecimento da repercussão social não é ato de julgamento - como se adiantou, em plena sintonia com os sistemas análogos, inclusive, com o da nossa arguição de relevância -, senão que é ato de avaliação política, prévio à possibilidade de admissão do recurso extraordinário." (Cf. op. cit., pp. 74-75).
} 
das linhas mestras definidas pelo conceito de Repercussão Geral ${ }^{102}$. Nos dizeres de JosÉ CARlos BARBosA MoReIRA, “deixando ao aplicador da norma, no momento da subsunção quer dizer, quando lhe caiba determinar se o fato singular e concreto com que se defronta corresponde ou não ao modelo abstrato - , o cuidado de preencher os claros, de cobrir os espaços em branco". 103

\section{Segundo Luiz Guilherme MARinoni e DANiEl Mitidiero, a existência de} Repercussão Geral revela-se através de fórmula binária que conjuga relevância + transcedência ${ }^{104}$, ou seja, a questão constitucional tratada deverá ser relevante, com alta carga

Rodolfo de Camargo Mancuso também entende que a decisão a respeito da presença da Repercussão Geral tem cunho predominantemente político: "Que o conteúdo ou a natureza da 'Repercussão Geral' é de cunho predominantemente político, no melhor sentido (inclusive no senso de 'política judiciária'), há um forte indicativo no fato de que, enquanto os atos tipicamente jurisdicionais são recorríveis quando contenham alguma carga decisória (CF, art. 5\%, LV; CPC, art. 496; $\$ 1^{\circ}$ do 557; art. 504, lido contrario sensu), já o art. 326 do RISTF, cf. ER 21/2007, declara que 'toda decisão de inexistência de Repercussão Geral é irrecorrível (...)' (embora, a nosso ver, tal dispositivo regimental deva merecer a devida interpretação sistemática, mormente à luz do disposto no $\$ 1^{\circ}$ do art. 557 do CPC)." (Cf. op. cit., p. 180).

Com o devido respeito e acatamento, não compartilhamos integralmente desse entendimento, uma vez que é preciso ter em mente que a função política outorgada pela Magna Carta ao Supremo Tribunal Federal, na medida em que lhe é dado definir, a cada caso concreto, a extensão do que vem a ser a "Repercussão Geral", é meramente secundária, pois advinda justamente de sua função jurisdicional, com o julgamento dos recursos a ela submetidos.

A despeito disso, muito embora não seja entendido como um ato verdadeira e exclusivamente político, não há como se negar a alta carga política desses julgamentos, permeados de influências externas ao ordenamento jurídico e tendentes a estabelecer verdadeira linha de política judiciária.

Compreendendo essa "dupla função", jurisdicional e política, do julgamento do Supremo Tribunal Federall, são as palavras de Ricardo de Barros Leonel: "Doravante, com a entrada em vigor da Lei 11.418/2006, ao analisar a existência da Repercussão Geral da questão constitucional, que servirá de verdadeiro filtro quanto aos casos que deverão, ou não, ser conhecidos estará o Pretório Excelso exercendo não apenas juízo técnico ou jurídico, mas também político." (Cf. op. cit., p. 175). E Carolina Brambila Bega: "Destarte, embora permeada por aspectos políticos (que também são verificados no controle concentrado de constitucionalidade - ADIN, ADC-, pois ninguém há de negar que também nestes casos a influencia política é ampla), a análise acerca da Repercussão Geral das questões constitucionais não passa de uma decisão de caráter jurisdicional, tanto que não pode deixar de ser fundamentada. (...) Conforme já asseveramos, trata-se de decisão jurisdicional, na qual o órgão julgador deve estar adstrito ao princípio da legalidade, ou melhor da constitucionalidade, sem esquecer, entretanto, que existe sim uma carga de política judiciária, que passa a ser ainda mais forte com o advento da Repercussão Geral." (Cf. Repercussão Geral das questões constitucionais - Aspectos processuais, p. 88).

Por fim, para que se conclua, definitivamente, pelo caráter jurisdicional do julgamento sobre a Repercussão Geral, vale citar as precisas palavras de André de Albuquerque Cavalcanti Abbud: "Ademais, a ocorrência de elementos não estritamente jurídicos (no sentido positivista) para o raciocínio judicial, como princípios, valores, máximas de experiência, ponderações de ordem econômica, política ou social etc. é traço que, além de presente em qualquer interpretação jurídica, em maior ou menor grau, marca sobremaneira toda exegese de cláusulas gerais e conceitos jurídicos indeterminados, como são os casos, respectivamente, da norma em que estipulada a exigência de Repercussão Geral e desta locução, em si mesma. Nem por isso, entretanto, o resultado desse labor hermenêutico, veiculado na decisão judicial, deixa de ser jurídico. É com esta feição que o sistema o acolhe, determinando seu regime e seus efeitos." (Cf. op. cit., 294).

102 "Em outras palavras, ao Supremo Tribunal Federal caberá o desvelamento do verdadeiro sentido do instituto, o que se dará caso a caso, dentro de um processo interpretativo fundamentado (art. 93, IX e X. da Constituição de 1988) e aberto cognitivamente, guiado pelo programa normativo semanticamente indeterminável a priori da Repercussão Geral." (Cf. Repercussão Geral sob a ótica da teoria dos sistemas de Niklas Luhmann, p. 45).

${ }^{103}$ Cf. Regras de Experiência e Conceitos Juridicamente Indeterminados, p. 64.

${ }^{104}$ Lecionam esses autores que "A transcendência da controvérsia constitucional levada ao conhecimento do Supremo Tribunal Federal ode ser caracterizada tanto em uma perspectiva qualitativa como quantitativa. Na 
de significação do ponto de vista econômico, político, social ou jurídico, e transcender aos interesses das partes, irradiando efeitos para além do processo $^{105}$.

Os juristas José Miguel Garcia Medina e Teresa Arruda Alvim Wambier entendem que a Repercussão Geral no âmbito econômico se revelaria em discussões acerca do Sistema Financeiro de Habitação ou da privatização de serviços públicos essenciais, como a telefonia e o saneamento básico, por exemplo. A repercussão no campo político estaria presente quando, por exemplo, delas pudesse resultar decisão capaz de influenciar nossas relações com Estados estrangeiros ou organismos internacionais. Já a transcendência do ponto de vista social se revelaria sempre que se discutissem questões relativas à educação, habitação ou mesmo à legitimidade do Ministério Público para a propositura de certas ações. E, por fim, estaríamos diante de causas com relevante interesse jurídico quando discutido conceito ou noção de um instituto básico de nosso ordenamento, e a decisão anteriormente proferida pudesse significar perigoso precedente, como o de direito adquirido ${ }^{106}$.

Também nesse sentido, a lição de HUMBERTO THEODORO JÚNIOR:

"I - no plano econômico, em primeiro lugar, há de se levar em conta as questões em torno daquelas atividades de larga repercussão coletiva que se encontram regulamentadas a partir da própria Constituição, como os serviços públicos essências (transportes coletivos, telefonia, energia, saneamento básico, etc.). São igualmente relevantes, para a coletividade, questões que envolvam pretensões reivindicadas por um número considerável de pessoas, a exemplo do que se passa com índices de correção monetária, remuneração de certos serviços ou de determinada categoria, sistema nacional de habitação, sistema tributário, etc. Em qualquer hipótese, porém, deve-se ter em conta que não basta a repercussão sobre o interesse de toda a coletividade ou de um grande numero de pessoas; é sempre indispensável que a questão atinja o nível constitucional, para que o recurso extraordinário chegue a ser apreciado pelo STF. A Repercussão Geral não é, em si, a chave para obter-se o julgamento do STF sobre o recurso extraordinário; é apenas um requisito a mais acrescido às condições de admissibilidade do recurso em questão.

II - A repercussão no plano político é facilmente detectável quando a questão em jogo no recurso extraordinário possa ter influencia em relações com estados estrangeiros ou organismos internacionais, ou no plano interno, quando

primeira, sobreleva para individualização da transcendência o importe da questão debatida para a sistematização e desenvolvimento do direito; na segunda, o número de pessoas susceptíveis de alcance, atual ou futuro, pela decisão daquela questão pelo Supremo Tribunal Federall e, bem assim, a natureza do direito posto em causa (notadamente, coletivo ou difuso)." (Cf. op. cit., p. 44).

105 “A fim de caracterizar a existência de Repercussão Geral e, destarte, viabilizar o conhecimento do recurso extraordinário, nosso legislador alçou mão de uma fórmula que conjuga relevância e transcendência (Repercussão Geral = relevância + transcendência). A questão debatida tem de ser relevante do ponto de vista econômico, político, social ou jurídico, além de transcender para além do interesse subjetivo das partes na causa. (...) Presente o binômio, caracterizada está a Repercussão Geral da controvérsia.” (Cf. op. cit., p. 40).

${ }^{106}$ Cf. op. cit., p. 377. 
envolva atritos de poder ou de competência entre órgãos da soberania ou ponha em risco política econômica pública ou diretrizes governamentais. Barbosa Moreira e Calmon de Passos lembram casos já vividos pela jurisprudência nacional em que políticas públicas foram postas em cheque por versarem causas numerosíssimas como as relacionadas com a correção monetária das contas de FGTS geridas pelo governo.

III - Reflexos sociais ocorrem sempre que a questão debatida seja daquelas que envolvam direitos coletivos ou difusos, como aqueles protegidos pela ordem constitucional em torno da saúde, educação, moradia, seguridade social, etc. É o que, com frequência, também se trava em temas debatidos em ação popular, ações civis públicas, mandado de segurança coletivo, etc.

IV - A relevância jurídica pode ser divisada quando esteja em jogo 'o conceito ou a noção de um instituto básico do nosso direito', havendo necessidade de evitar que uma decisão forme precedente perigoso ou inconveniente, como, v.g., em relação ao direito adquirido e outros valores constitucionais muito importantes para a prevalência da interpretação legítima da Constituição que ao STF compete realizar."107

Importante - e reconhecida - contribuição para a elucidação de hipóteses em que inegavelmente presente a Repercussão Geral foi dada por JosÉ CARLOS BARBOSA MoREIRA, quando ainda vigente o instituto da arguição de relevância. Destacou o jurista, seguido e citado por muitos outros doutrinadores ${ }^{108}$, as seguintes ocorrências:

(i) Questão "capaz de influir concretamente, de maneira generalizada, numa grande quantidade de casos";

(ii) Questão cuja decisão pleiteada seja tal que "sirva à unidade e ao aperfeiçoamento do direito”, enfim, hipóteses que "sejam particularmente significativas para o desenvolvimento do direito";

(iii) Questões "que tenham imediata importância jurídica ou econômica para círculo mais amplo de pessoas ou para mais extenso território da vida pública";

(iv) Questões "que possam ter como consequência a intervenção do legislador no sentido de corrigir o ordenamento positivo ou de suprir-lhe lacunas";

(v) Questões "que sejam suscetíveis de exercer influência capital sobre as relações com Estados estrangeiros ou com outros sujeitos do direito internacional público".

Em suma, estará presente a Repercussão Geral sempre que houver transcendência do interesse na solução do conflito para fora da causa em si, ou quando a questão tratada seja apta a repercutir na esfera jurídica de um número considerável de pessoas.

\footnotetext{
${ }^{107}$ Cf. op. cit., pp. 108-110.

${ }^{108}$ Como Eduardo Talamini, Leonardo Carneiro da Cunha, Calmon de Passos, entre outros.
} 
Ainda, haverá Repercussão Geral quando o julgamento de certo recurso tenha o condão de sinalizar o posicionamento jurídico-processual que deve ser dado a certa questão constitucional, orientando a produção jurisprudencial.

Há que se notar, de outro lado, que a adoção de conceitos jurídicos indeterminados, cuja necessidade de interpretação é ampla e casuística, não se confunde com a ampliação do poder discricionário do Poder Judiciário.

Nesse sentido, o exercício interpretativo que se deve fazer, à luz de um caso concreto, para que seja aferida a presença da Repercussão Geral da questão constitucional não significa que o Supremo Tribunal Federal está dotado de absoluta discricionariedade para proferir sua decisão ${ }^{109-110}$.

O que existe, em verdade, quando presentes conceitos jurídicos assim indeterminados, é uma maior liberdade conferida ao aplicador da lei para que fixe esses conceitos, à luz do caso concreto ${ }^{111}$.

Nesse sentido, ARRUDA ALVIM bem diferenciou a discricionariedade propriamente dita, vigente na esfera administrativa, daquela discricionariedade judicial. Segundo ele,

\begin{abstract}
"A discricionariedade, como instituto ensejador de dualidade, ou pluralidade de soluções, todas igualmente válidas, em face da lei, que as encampa, dependentemente da motivação justificadora da eleição de um ou outro caminho, deve, todavia, ser distinguida das hipóteses em que existe, apenas, uma maior intensidade de 'valoração' por parte do juiz. Para estas hipóteses, somente num sentido impróprio se haverá de falar em discricionariedade, porquanto, estas outras normas, ainda que proporcionando amplo espectro de indagação/decisão, para o magistrado, são intencionalmente preordenadas a terem, num dado momento e num dado lugar, somente uma interpretação, para o fim de abrangerem ou não uma dada hipótese". ${ }^{112}$
\end{abstract}

\footnotetext{
${ }^{109}$ Nas palavras de José Rogério Cruz e Tucci, "os critérios que serão estabelecidos para o exame a avaliação da Repercussão Geral jamais poderão ser discricionários, até porque a Corte deverá explicitar a respectiva ratio decidendi." (Cf. op. cit., p.25).

110 "Por mais vaga que possa ser a exigência do requisito da Repercussão Geral no juízo de admissibilidade do recurso extraordinário, nunca estará o STF livre para rejeitar arbitrariamente um recurso sobre a lacônica e imotivada alegação de ausência de tal requisito. Sempre terá de proceder ao esforço dialético de demonstrar, analiticamente, como se chegou ao juízo determinante da falta de Repercussão Geral, submetendo o caso concreto às exigências da razoabilidade." (Cf. Repercussão Geral no Recurso Extraordinário (Lei n ${ }^{o}$ 11.148) e Súmula Vinculante do Supremo Tribunal Federal (Lei n $\left.n^{\circ} 11.417\right)$, p. 106).

${ }^{111}$ Nesse sentido, é a lição de José Roberto dos Santos Bedaque: "quando se quer tratar de discricionariedade judicial, a expressão entre nós há de significar apenas a maior ou menor liberdade de o juiz adaptar (ou interpretar) as normas aos casos concretos, de tal sorte que o magistrado não tem liberdade de escolher uma entre várias possibilidades de aplicar a norma: em verdade, espera-se dele que aplique a norma da única forma correta, dando ao caso concreto a solução imaginada ou desejada pelo legislador." (Cf. Discricionariedade Judicial, p. 187).

${ }^{112}$ Cf. op. cit., p. 16.
} 
Nas hipóteses de discricionariedade administrativa, portanto, a norma jurídica oferece duas ou mais soluções, igualmente válidas e passíveis de escolha pelo administrador, para a feitura de determinado ato administrativo. Elege-se um determinado caminho, em detrimento dos demais existentes; e tal escolha é feita tendo como base um juízo de conveniência e oportunidade.

Já nas hipóteses da chamada discricionariedade judicial, não existe a possibilidade de escolha entre duas soluções possíveis; existe, sim, o dever do julgador à aplicação correta e precisa da norma jurídica, não se permitindo a escolha com base em critérios de oportunidade e conveniência.

Assim, ainda que diante de um conceito vago e indeterminado, a interpretação adotada pelo magistrado não poderá acarretar dualidade de soluções, em um mesmo momento e sob as mesmas circunstâncias. Se presentes, rigorosamente, idênticas condições, a interpretação de um dado conceito jurídico pelo Poder Judiciário comportará apenas, e sempre, um único entendimento ${ }^{113}$.

Nesse sentido, as lições de LuIZ GuILHERME MARINONI E DANIEL MitidiERO:

"Os conceitos jurídicos indeterminados são compostos de um 'núcleo conceitual' (certeza do que é ou não é) e por um 'halo conceitual' (dúvida do que pode ser). No que concerne especificamente à Repercussão Geral, a duvida inerente à caracterização desse halo de modo nenhum pode ser dissipada partindo-se tão somente de determinado ponto de vista individual; não há, em outras palavras, discricionariedade no preenchimento desse conceito. Há de se empreender um esforço de objetivação valorativa nessa tarefa. E, uma vez caracterizada a relevância e a transcendência da controvérsia, o Supremo Tribunal Federal encontra-se obrigado a conhecer do recurso extraordinário. Não há, aí, espaço para livre apreciação e escolha entre duas alternativas igualmente atendíveis. Não há de se cogitar aí, igualmente, de discricionariedade no recebimento do recurso extraordinário. Configurada a Repercussão Geral, tem o Supremo Tribunal Federal de admitir o recurso e apreciá-lo no mérito." 114

Conclui-se, portanto, a partir do raciocínio acima explanado, que não há discricionariedade por parte do Supremo Tribunal Federal para fins de detecção da presença

\footnotetext{
${ }^{113}$ Também esta é a posição de Eduardo Talamini: "Na atividade jurisdicional de definição concreta dos conceitos jurídicos indeterminados não há discricionariedade - no sentido em que essa expressão é tradicionalmente usada no direito público brasileiro. Apenas há discricionariedade quando o agente se vê diante de duas opções que são igualmente aceitáveis do ponto de vista jurídico, de modo que escolherá uma ou outra por razões de conveniência ou oportunidade. Isso não ocorre na hipótese. Ou a questão reveste-se de repercussão ou não se reveste - uma hipótese exclui a outra." (Cf. op. cit., p. 37).

${ }^{114}$ Cf. op. cit., pp. 41-42.
} 
de Repercussão Geral ${ }^{115}$. Diante de casos absolutamente idênticos, a interpretação do conceito indeterminado da Repercussão Geral não autoriza a adoção de soluções jurídicas distintas.

Nesse ponto, destaca EdUARdo TALAmini que a intensificação de meios de controle da atividade jurisdicional funciona como contraponto à eventual discricionariedade por parte do STF, através do fortalecimento de garantias como o contraditório, devido processo legal e a exigência de fundamentação adequada das decisões:

"Assim, à maior liberdade de atuação à luz das circunstâncias concretas deve corresponder uma intensificação dos meios de controle e da responsabilidade do juiz com: o incremento da garantia do contraditório, de modo a abranger o dever de debate do juiz com as partes; a exigência de decisões com fundamentação completa, racional e controlável; o reconhecimento de que as decisões são recorríveis inclusive no ponto em que aplicam os conceitos indeterminados; a exigência de uma relativa estabilidade das decisões tomadas - e assim por diante.

Em um contexto de vigência da garantia do devido processo legal, isso significa que a outorga de poderes aos órgãos jurisdicionais mediante normas com conceitos indeterminados não lhes confere a prerrogativa de decidir dispensando-se de motivar e de submeter-se ao crivo do contraditório e ao controle de suas decisões. Bem o contrário, quanto maior a margem de 'liberdade' para a definição concreta dos conceitos normativos propiciada por sua indeterminação abstrata, mais intensa é a imposição daqueles deveres." 116 117

Em suma, quando da interposição de recurso extraordinário, o recorrente estará obrigado a demonstrar, preliminarmente, que a questão discutida nos autos transcende os interesses litigantes, sob o prisma econômico, político, social ou jurídico, fazendo jus a uma análise mais profunda e detalhada pelo Supremo Tribunal Federal, de modo a fixar um

\footnotetext{
${ }^{115}$ Entende Bruno Dantas que "a atividade do STF na averiguação da existência de Repercussão Geral nas questões constitucionais discutidas num dado RE, longe de ser discricionária, será tão somente de investigação crítica do caso." (Cf. op. cit., p. 281).

${ }^{116}$ A respeito do aparente conflito existente entre o quanto exposto pelo autor e a irrecorribilidade das decisões proferidas pelo STF a respeito da presença, ou não, da Repercussão Geral da questão constitucional, Talamini explica que "mesmo em face da irrecorribilidade da decisão do Plenário acerca da Repercussão Geral, permanece relevante e válida a negativa de discricionariedade. Primeiro, porque não é dado ao STF agir com base em tal premissa (de que seria discricionária a sua atuação), sob pena de aniquilar as próprias regras que the conferem título legítimo para atuar. Depois, porquanto sua atuação, ainda que irrecorrível, permanece submetida ao controle social. Esse controle é cada vez mais intenso e significativo na medida em que a própria Corte amplia a divulgação de suas atividades (com transmissão de julgamentos em rede de televisão; distribuição regular de informativos em que são noticiadas em termos claros as suas decisões...). O mero fato de essa atividade divulgadora provir do próprio STF é indicativo de que o Tribunal (i.e., seus membros) tem ciência da premissa a partir da qual deve atuar.

De resto, é apenas a recorribilidade da decisão que fica excluída, e por uma imposição lógica: trata-se já de pronunciamento do órgão último do Tribunal de cúpula. Eis um limite compatível com a razoabilidade inerente ao due process. As demais garantias antes referidas incidem plenamente: publicidade, fundamentação das decisões, contraditório - ampliado pela admissão de amicus curiae..." (Cf. op. cit., p. 40).

${ }^{117}$ Cf. op. cit., p. 38.
} 
posicionamento definitivo sobre o tema, observando-se o adequado atendimento às garantias do devido processo legal.

Será, portanto, em face de casos concretos e da aplicação cotidiana que se fixará o real sentido e dimensão desse novo instituto jurídico ${ }^{118-119}$.

Daí porque falar-se na importância do decurso do tempo e do acúmulo de julgados sobre o tema, elucidando o próprio conceito, sem que se fechem as portas para novas e imprevistas hipóteses ${ }^{120}$.

3.2.2 A natureza jurídica da Repercussão Geral: novo requisito de admissibilidade do recurso extraordinário

Da leitura do preceito normativo constitucional, já é possível vislumbrar a natureza jurídica do instituto da Repercussão Geral: o constituinte destaca, expressamente, a necessidade de demonstração da Repercussão Geral das questões constitucionais discutidas no caso, a fim de que o Supremo Tribunal Federal examine a admissão do recurso ${ }^{121}$.

Ademais, o objetivo precípuo do instituto, de filtrar e selecionar os recursos extraordinários que aportam ao Supremo Tribunal Federal, também revela que o exame da presença da Repercussão Geral se insere no âmbito da admissibilidade do recurso extraordinário $^{122}$.

\footnotetext{
118 "Com efeito, a partir de uma paulatina e natural formação de catálogo de casos pelos julgamentos do Supremo Tribunal Federal permite-se o controle em face da própria atividade jurisdicional da Corte, objetivando-se cada vez mais o manejo dos conceitos de relevância e transcendência ínsitos à ideia de Repercussão Geral.” (Cf. Repercussão Geral no recurso extraordinário, p. 42).

119 “(...) cabe concluir para a boa inteligência da lei inovadora do regime do recurso extraordinário, que muito importante é o papel a ser desempenhado pela jurisprudência do STF na construção da teoria da Repercussão Geral no âmbito do recurso extraordinário. Com o passar do tempo, o acumular de precedentes e a coerência detectada entre os sucessivos pronunciamentos acerca dos casos avaliados levará à melhor compreensão do importante mecanismo constitucional de acesso à Suprema Corte, tornando mais previsível o cabimento, ou não, dos recursos da espécie nas circunstâncias concretas dos litígios." (Cf. Repercussão Geral no Recurso Extraordinário (Lei $n^{o}$ 11.148) e Súmula Vinculante do Supremo Tribunal Federal (Lei $n^{\circ}$ 11.417), p. 107).

120 "O enriquecimento do perfil, múltiplo e multifacetado, do que é a relevância, decorrerá dos casos que venham, paulatinamente, sendo acolhidos, de tal forma que isso se fará crescentemente, ao longo do tempo (...). Com o decurso do tempo, inclusive, esse perfil virá ganhar nitidez e poderá, até, vir a alterar-se em alguns pontos, mas não perderá o atributo da nitidez, que haverá de perdurar. A modificação dos elementos componentes desse quadro de hipóteses não lhe subtrai os elementos fundamentais, e, nem desfigura as regras que informam o sistema." (Cf. A arguição de relevância no recurso extraordinário, p. 170).

${ }_{121}$ Art. 102, § 3 $3^{\circ}$, CF: "No recurso extraordinário o recorrente deverá demonstrar a Repercussão Geral das questões constitucionais discutidas no caso, nos termos da lei, a fim de que o Tribunal examine a admissão do recurso, somente podendo recusá-lo pela manifestação de dois terços de seus membros."

122 "Isso porque, sendo instituto inescondível e flagrantemente voltado ao estabelecimento de filtro de acesso ao STF pela via recursal extraordinária, o desiderato restritivo só se aperfeiçoaria com a criação de óbice à própria admissibilidade do recurso." (Cf. Repercussão Geral: perspectivas históricas, dogmática e de direito comparado: questões processuais, p. 228).
} 
Assim, o instituto da Repercussão Geral pode ser considerado um novo requisito intrínseco de admissibilidade dos recursos extraordinários ${ }^{123}$, que atua como um mecanismo de filtragem, permitindo que apenas alcancem o Supremo Tribunal Federal as teses dotadas de real importância e significado ${ }^{124-125}$.

Contudo, muito embora se trate de um requisito intrínseco de admissibilidade do recurso extraordinário ${ }^{126}$, o exame da presença da Repercussão Geral não se insere no tradicional modelo de juízo de admissibilidade bipartido ${ }^{127}$ dos recursos dessa espécie.

${ }^{123}$ Especificamente quanto aos requisitos de admissibilidade do apelo em questão - divididos, como leciona Araken de Assis, em requisitos intrínsecos, relacionados com a existência, ou não, do poder de recorrer, tais como cabimento, legitimidade, interesse e legitimidade para recorrer; e extrínsecos, relacionados ao modo como esse poder de recorrer é exercido, como a tempestividade, regularidade formal e preparo ${ }^{123}$ - parece claro que a Repercussão Geral se insere, nesse contexto, como um novo requisito intrínseco de admissibilidade do recurso extraordinário, tanto por independer de qualquer fator externo (como o recolhimento de custas, por exemplo), quanto por vincular-se, exclusivamente, à decisão recorrida. (Cf. op. cit., pp. 135 a 211).

Sobre os pressupostos gerais dos recursos, Humberto Teodoro Júnior os elenca da seguinte forma: "a) $a$ recorribilidade da decisão; b) a tempestividade do recurso; c) a singularidade do recurso; d) a adequação do recurso; e) o preparo; f) a motivação; e g) a forma." (Cf. op. cit., pp. 646-653).

${ }^{124}$ Eduardo Talamini classifica a Repercussão Geral, no âmbito dos requisitos intrínsecos de admissibilidade do recurso extraordinário, como um pressuposto específico do requisito de cabimento do apelo: "A lei confirma tratar-se de um pressuposto de admissibilidade do recurso extraordinário. (...) A rigor, pode-se aludir a uma especificação - ou melhor, a uma intensificação - do pressuposto recursal atinente ao cabimento (que é um dos pressupostos recursais intrínsecos). Antes, o recurso caberia desde estivesse presente questão constitucional delineada conforme alguma das hipóteses das alíneas do inciso III do art. 102 da Constituição. Agora, seu cabimento depende ainda de essa questão revestir-se de Repercussão Geral. Ou seja, adicionou-se a exigência de uma especial qualificação da questão constitucional, a fim de que o pressuposto do cabimento do recurso possa ser considerado cumprido." (Cf. op. cit., p. 33).

Também entende assim Bruno Dantas: "A natureza jurídica do instituto da Repercussão Geral, segundo nos parece, é de pressuposto específico de cabimento do recurso extraordinário, de modo que, embora dotado de peculiaridades, se insere no juízo de admissibilidade desse recurso." (Cf. op. cit., pp. 227-228).

${ }_{125}$ Nas palavras de Marinoni e Mitidiero: "Trata-se de requisito intrínseco de admissibilidade recursal: não havendo Repercussão Geral, não existe poder de recorrer ao Supremo Tribunal Federal". (Cf. op. cit., p. 39).

No mesmo sentido, Carolina Brambila Bega: "Por estar diretamente ligado à possibilidade de recorrer e portanto à recorribilidade (somente é possivel o uso do Recurso Extraordinário quando a questão for dotada de Repercussão Geral), concluímos que o instituto veio para integrar a análise do cabimento. (...) Não restam dúvidas, portanto, de que a Repercussão Geral das questões constitucionais é requisito de admissibilidade do Recurso Extraordinário, prejudicial ao mérito, cuja decisão não vincula a decisão final, inserindo-se como mais um aspecto do cabimento recursal, autônomo, mas cumulativo aos demais." (Cf. op. cit., pp. 81-82). E Medina e Wambier: "Os argumentos que devem levar o Tribunal a entender que a questão tem Repercussão Geral devem constar do próprio recurso e serão analisados quando do juízo de admissibilidade." (Cf. op. cit., p. 201).

Também Araken de Assis insere a Repercussão Geral no rol dos requisitos de admissibilidade do recurso extraordinário, dentro do pressuposto de cabimento, que se desdobra, então, em quatro facetas: (i) o esgotamento das vias ordinárias, (ii) o prequestionamento da questão constitucional, (iii) a ofensa direta à Constituição e (iv) a Repercussão Geral da questão constitucional versada no recurso. (Cf. op. cit., p. 679).

Ricardo de Barros Leonel afirma que é possível "asseverar, assim, que a avaliação sobre a existência da Repercussão Geral nada mais é que a análise sobre um novo pressuposto de admissibilidade do recurso extraordinário, criado pela EC 45/2004, bem como pela Lei 11.418/2006." (Cf. op. cit., pp. 171-172).

Ainda, André de Albuquerque Cavalcanti Abbud: "Afinal, a Repercussão Geral foi acrescida aos demais pressupostos genéricos e específicos previstos na lei processual, passando a integrar o objeto do juízo de admissibilidade do recurso extraordinário, realizado previamente a seu juízo de mérito, e cujo resultado positivo é condição sine qua non para que este último ocorra. Desprovida a vexata quaestio de Repercussão Geral, o recurso não poderá ser conhecido, independentemente da presença dos demais requisitos legais." (Cf. op. cit., p. 293).

${ }^{126}$ Entende diferentemente o ilustre Professor Rodolfo de Camargo Mancuso, para quem a Repercussão Geral da questão constitucional deve ser considerada um "pré-requisito genérico ao juízo de admissibilidade do RE", cuja 
A uma, por força do próprio teor da norma jurídica constitucional, que estabelece, com exclusividade, ao Supremo Tribunal Federal a competência para examinar e decidir pela presença, ou não, da Repercussão Geral tratada no caso concreto ${ }^{128-129}$. E, a duas, graças ao diferenciado quórum exigido para que se afaste, fundamentadamente, a presença da Repercussão Geral - fixado também constitucionalmente, em dois terços dos membros do STF.

Tais diferenças se justificam graças ao viés político, já anteriormente mencionado, do julgamento proferido pelo Supremo Tribunal Federal, responsável por exercer controle dessa natureza, como uma das formas de salvaguarda da Magna Carta. São, portanto, de

presença deve ser aferida antes mesmo do exame dos demais requisitos de admissibilidade do recurso. Nesse sentido, sustenta que: "A 'Repercussão Geral' é um pré-requisito genérico ao juízo de admissibilidade do RE, porém manejável secundum eventum: (i) quando a avaliação resulta negativa, é absoluta e excludente, dispensando o exame dos pressupostos objetivos e subjetivos de admissibilidade (prazo, preparo, prequestionamento, adequação, interesse, legitimidade), inclusive projetando eficácia panprocessual (CPC, $\S 5^{\circ}$ do art. 543-A; $\$ 2^{\circ}$ do art. 543-B; RISTF, art. 326, cf. ER 21/2007); (ii) quando a avaliação resulta positiva, é relativa e não necessariamente includente, porque não assegura, de per si, que o recurso vá ser conhecido (o que fica a depender do atendimento aos pressupostos de admissibilidade) nem que vá ser provido: apenas significa o reconhecimento, pelo STF de que o RE apresenta relevância tal que transcende os interesses das partes, avaliação essa que, uma vez somada ao atendimento dos demais pressupostos formais, libera, enfim, o julgamento do mérito recursal." (Cf. op. cit., p. 185).

${ }^{127}$ Segundo o qual tanto o Presidente (ou Vice-Presidente) do Tribunal recorrido quanto o Supremo Tribunal Federal têm competência para examinar os pressupostos de admissibilidade recursal.

128 "A atribuição de competência exclusiva ao STF para a identificação da Repercussão Geral é uma decorrência lógica da finalidade do instituto. Uma vez que a Repercussão Geral presta-se a qualificar a atuação do Supremo Tribunal Federall nas questões constitucionais - e ela precisa ser identificada por algum órgão jurisdicional, pois não tem como ser prévia e abstratamente definida na Constituição -, há de caber a ele, STF, e não aos outros órgãos jurisdicionais, definir o perfil que deverá adotar como Corte Constitucional, por meio da seleção das questões relevantes." (Cf. Novos aspectos da jurisdição constitucional brasileira: Repercussão Geral, força vinculante, modulação dos efeitos do controle de constitucionalidade e alargamento do objeto do controle direto, p. 26-27).

${ }^{129}$ A esse respeito, vale reforçar a observação bem pontuada por Medina e Wambier, no sentido de que, embora seja o STF exclusivamente competente para apreciar a questão e decidir pela presença, ou não, de Repercussão Geral da questão constitucional tratada em determinado recurso extraordinário, o Presidente ou Vice-Presidente do Tribunal recorrido ainda detém competência para analisar, in casu, a presença, ou não, da preliminar de Repercussão Geral, podendo inadmitir o recurso extraordinário que não apresentar tal regularidade formal: " $A$ ausência de preliminar de Repercussão Geral, no entanto, pode ser detectada pelo órgão a quo, que, no caso, indeferirá o recurso extraordinário em razão da ausência de regularidade formal deste recurso (e não, propriamente, em razão da ausência de Repercussão Geral)". (Cf. op. cit., p. 70). Nesse mesmo sentido, pontua Humberto Theodoro Júnior que "esse juízo local de admissibilidade não inclui a aferição da Repercussão Geral, cujo exame é exclusivo do STF (CPC, art. 543-A, $\S 2^{\circ}$ ). Formalmente, no entanto, haverá de figurar no recurso, de maneira obrigatória, a demonstração de que a questão constitucional nele aventada oferece repercussão que ultrapassa os interesses subjetivos da causa. A ausência de tal capítulo torna inepta a petição recursal. $O$ presidente (ou vice-presidente) do Tribunal a quo, portanto, poderá inadmitir o extraordinário, não pela proclamação de falta de Repercussão Geral, mas por ausência objetiva de um requisito indispensável da petição." (Cf. op. cit., p. 119). Por fim, Taís Schilling Ferraz sustenta que "Os tribunais de segundo grau, os tribunais superiores e as turmas recursais, inclusive a Turma Nacional de Uniformização - TNU - têm atribuição par proceder ao exame formal, isto é, se o recurso extraordinário traz, em seu texto, de forma destacada ou no bojo das alegações, fundamentação específica, voltada a demonstrar a presença de Repercussão Geral na questão constitucional suscitada. Em não havendo alegação de Repercussão Geral no recurso, em preliminar formal e fundamentada, poderá ser ele inadmitido já na instância recursal de origem." (Cf. Repercussão Geral - muito mais que um pressuposto de admissibilidade, p. 85). 
especificidades que não desnaturam, mas antes reforçam, o caráter seletor e relativo à admissibilidade da Repercussão Geral dos apelos extraordinários.

Como explicita BRUNO DANTAS:

"isso denota que, embora a Repercussão Geral seja a manifestação de requisito intrínseco de admissibilidade, ela apresenta uma especificidade, decorrente de expresso comando constitucional, que a torna de status diferenciado dos demais pressupostos do cabimento, como o prequestionamento e o prévio esgotamento das instâncias ordinárias. Diferentemente desses, que podem ser aferidos monocraticamente, a Repercussão Geral pressupõe análise coletiva, com ao menos 'oito cabeças' a examinar o mesmo assunto, pois só o voto de dois terços dos membros do STF é que se pode reconhecer a sua ausência, o que, se não assegura que a justiça será feita, sem sombra de dúvidas torna a decisão sobremaneira mais qualificada." 130

Deve-se ressaltar, no entanto, que mesmo a existência de Repercussão Geral, já reconhecida pelo Supremo Tribunal Federal, não implica na automática admissibilidade do recurso extraordinário.

Devem ser satisfeitos, também, os demais requisitos formais exigidos pela legislação. Como bem ressalta GlaUCIA MARA COELHO, “não basta a presença da Repercussão Geral para que o apelo extremo seja admitido, sendo necessária a presença concomitante de todos os demais pressupostos de admissibilidade (genéricos e específicos) dos recursos extraordinários para o cabimento do apelo" ${ }^{\prime 131}$.

Assim, posto que a presença de Repercussão Geral não importa na imediata admissibilidade do recurso extraordinário no bojo do qual é veiculada, com ainda maior razão é de se dizer que o reconhecimento da transcendência e relevância da questão constitucional não se traduz em automático provimento do recurso.

Isso porque o exame da preliminar de Repercussão Geral, enquanto requisito de admissibilidade do recurso extraordinário, é anterior ao exame do mérito do recurso - muito embora com ele possa se confundir, em algumas hipóteses, ainda que superficialmente ${ }^{132}$.

\footnotetext{
${ }^{130}$ Cf. op. cit., p. 230.

${ }^{131}$ Cf. Repercussão Geral da questão constitucional no processo civil brasileiro, p. 128.

${ }^{132}$ Daí porque parte da doutrina especializada afirme que a Repercussão Geral não pode ser considerada como requisito estritamente processual, pois, por vezes, na tarefa de se atestar sua existência, é preciso adentrar, ainda que superficialmente, ao mérito da questão constitucional discutida. Contudo, lembramos que essa tênue linha existente entre a admissibilidade e o mérito do apelo extraordinário também se mostra marcante em relação à necessidade de demonstração da ofensa à Constituição, nos termos do art. 102, III, alínea $a$, da CF - confusão esta, no entanto, não é suficiente para destituir o caráter preliminar e de admissibilidade de qualquer um desses dois requisitos. Este também é o entendimento de Carolina Brambila Bega: "Não ignoramos, entretanto, o fato de que a Repercussão Geral pode por vezes se confundir com o próprio exame do mérito recursal, pois somente ao analisar a matéria do recurso é que se pode avaliar se este seria capaz de irradiar efeitos extra partes. Tal
} 
Outro aspecto bastante controvertido na doutrina diz respeito ao momento adequado à verificação da presença de Repercussão Geral. Questiona-se se o Supremo Tribunal Federal deve decidir pela sua existência antes de verificar a presença dos demais requisitos de admissibilidade, ou se imediatamente após essa análise.

Rodolfo de Camargo Mancuso e Arruda Alvim encabeçam a lista dos que entendem pela necessidade de aferição da presença de Repercussão Geral previamente ao exame de todos os demais requisitos de admissibilidade do recurso extraordinário. A principal razão desse entendimento repousa no fato de que a avaliação da presença de Repercussão Geral não seria um ato jurisdicional propriamente dito, mas antes um ato de avaliação política, razão pela qual não pode se confundir com o juízo de admissibilidade recursal ${ }^{133}$.

Todavia, entende-se estar com a razão a corrente doutrinária que considera que o exame da Repercussão Geral só deve ser realizado após a análise da presença de todos os demais pressupostos de admissibilidade do recurso extraordinário.

Não parece fazer sentido exigir que os Ministros do Supremo Tribunal Federal se debrucem sobre a intrincada questão da presença de Repercussão Geral, em sessão colegiada da Turma ou do Plenário, para que, depois, se perceba que o recurso extraordinário examinado não deve ser conhecido, por ausência de um dos requisitos formais de admissibilidade clássicos, como a tempestividade, preparo, prequestionamento, entre outros. Não é lógico, portanto, que um mecanismo criado com o intuito de selecionar e reduzir o volume de feitos que aportam ao Supremo Tribunal Federal, funcionando como verdadeiro filtro racionalizador do trabalho de todo o Poder Judiciário, implique em fonte de retrabalho ao STF - fato este reconhecido até mesmo por quem sustenta posição contrária ${ }^{134}$.

Vale lembrar, ademais, que o Tribunal a quo já realiza, em um primeiro momento, um exame de admissibilidade do recurso extraordinário, bastando ao Relator que confira o

hipótese seria semelhante ao que já vem preconizando a doutrina acerca da alínea a do art. 102, III, CF. Isto porque, nesses casos, o recurso visa propriamente demonstrar que no caso concreto houve a ofensa à Constituição o que, em princípio, causaria confusão entre admissibilidade e mérito. Vislumbramos que na Repercussão Geral pode ocorrer o mesmo fenômeno, porque, ainda que após admitido o recurso este possa ser julgado procedente ou não, muitas vezes as razões utilizadas para aferir a Repercussão Geral seriam as razões de decidir do próprio recurso, havendo dificuldade na dissociação de ambos." (Cf. op. cit., p. 82, nota de rodapé n. 139).

${ }^{133}$ Os autores mencionados são partidários da ideia de que a presença de Repercussão Geral deve ser aferida antes mesmo do juízo de admissibilidade, uma vez que se trata de pressuposto especial, de caráter político, e não jurídico: "É inconfundivel com a admissibilidade propriamente dita (com a verificação do cabimento/enquadramento do recurso nas hipóteses do artigo 102 da CF e legislação ordinária), a qual é juízo preambular já dentro do procedimento de julgamento do recurso" (Cf. op. cit., p. 64).

${ }^{134}$ Como o já mencionado Professor RODOLFO DE CAMARGO MANCUSO, ao apontar que "ao ângulo pragmático, poderá resultar alguma perda de atividade se, examinada primeiramente a Repercussão Geral, com avaliação positiva, na sequência se verifique, por exemplo, que o recurso está deserto ou é intempestivo, assim inviabilizando o exame de seu mérito." (Cf. op. cit., p. 206). 
acerto de tal análise, monocraticamente. Ultrapassada essa questão, de menor complexidade, aí sim, poderão os Ministros deliberar sobre a presença da Repercussão Geral ${ }^{135-136}$.

Ademais, a orientação do próprio Supremo Tribunal Federal é no sentido de que, antes, deve ser avaliada a satisfação dos requisitos de admissibilidade do recurso extraordinário, a qual, se positiva, poderá ser seguida, então, da submissão da questão da Repercussão Geral aos demais Ministros da Corte.

Ilustres doutrinadores também defendem essa posição.

Para LuIZ GuILHERME MARINONi E DANIEl MitidiERo o exame da Repercussão

Geral deve ser realizado apenas quando ultrapassada a análise de admissibilidade do recurso:

"Registrado e distribuído o recurso, procederá previamente o relator ao exame de sua admissibilidade. Poderá o relator, nesse momento, não admitir o recurso extraordinário por exemplo, por intempestividade ou por ausência de afirmação de violação de questão constitucional na decisão recorrida. $\mathrm{O}$ art. 557 do CPC pode ser invocável (art. $21, \S 1^{\circ}$, RISTF $\left[\S 1^{\circ}\right.$ com redação determinada pela Emenda Regimental STF 21/2007]). Não sendo esse o caso, levará à Turma para apreciação da existência ou não da Repercussão Geral da controvérsia constitucional (art. 323, RISTF [artigo com redação determinada pela Emenda Regimental STF 42/2010]). Decidindo esse órgão fracionário pela existência de Repercussão Geral por, no mínimo, quatro votos, ficará dispensada a remessa do recurso ao Plenário (art. 543-A, § 4º , do CPC). Não exige a legislação,

\footnotetext{
135 Em que pese nos pareça clara a necessidade de aferição, pelo Supremo Tribunal Federal, dos demais requisitos, intrínsecos e extrínsecos, de admissibilidade do recurso extraordinário previamente à análise da presença de Repercussão Geral da questão constitucional nele ventilada, o mesmo não se pode dizer do juízo de admissibilidade dos recursos múltiplos que restaram sobrestados pelos Tribunais de Segunda Instância (art. 543B, do Código de Processo Civil). Segundo a Emenda Regimental no 23/2008, que introduziu o art. 328-A no Regimento Interno, a orientação do Supremo Tribunal Federal é a de que os Tribunais a quo não emitam juízo de admissibilidade sobre os recursos extraordinários já sobrestados, até que seja julgada a Repercussão Geral (Art. 328-A. Nos casos previstos no art. 543-B, caput, do Código de Processo Civil, o Tribunal de origem não emitirá juízo de admissibilidade sobre os recursos extraordinários já sobrestados, nem sobre os que venham a ser interpostos, até que o Supremo Tribunal Federal decida os que tenham sido selecionados nos termos do $\S 1^{\circ}$ daquele artigo). Tal orientação - também adequada, a nosso ver - tem o intuito de evitar que o Supremo Tribunal Federal seja, novamente, sobrecarregado com a interposição de recursos de agravo de instrumento contra as decisões que não conhecerem desses recursos extraordinários já sobrestados, em virtude da ausência de outro requisito de admissibilidade. Reconhecida pelo STF a ausência de Repercussão Geral sobre a questão constitucional versada nesses recursos, serão eles inadmitidos por decisão irrecorrível, como se sabe, transitando definitivamente em julgado. Sobre o tema, Taís Schilling Ferraz: "Em um contexto de racionalização, em que se pretende o efeito multiplicador das decisões do STF, evitando que cada caso chegue individualmente, quando versar questão já decidida ou a ser decidida pela Corte, em que se busca evitar que processos sejam finalizados com soluções contraditórias em matéria de interpretação da Constituição, com prejuízos à isonomia em que se podem poupar ações rescisórias para reverter julgamentos contrários ao entendimento do STF, é preciso dar nova significação aos requisitos de admissibilidade dos recursos extraordinários. É preciso interpreta-los à luz do novo regime constitucional e legal." (Cf. op. cit., p. 93).

${ }^{136}$ Esse entendimento resta corroborado, inclusive, pelo Regimento Interno do STF, que, em seu art. 323, caput, dispõe que "quando não for caso de inadmissibilidade do recurso por outra razão, o(a) Relator(a) ou o Presidente submeterá, por meio eletrônico, aos demais Ministros, cópia de sua manifestação sobre a existência, ou não, de Repercussão Geral."
} 
portanto, que o Plenário do Supremo Tribunal Federal analise, prioritária e isoladamente, o requisito da Repercussão Geral.",137

Esse também é o entendimento de RICARDO DE BARROS LEONEL:

"Na prática, o processamento do recurso extraordinário funcionará da seguinte forma, aqui simplificada: a) o juízo de admissibilidade quanto aos demais pressupostos para o conhecimento do recurso continuará sendo realizado tanto pelo Tribunal recorrido, inicialmente, como, num segundo momento, pelo STF; b) após a admissão do recurso na origem ele será encaminhado ao STF, onde será reavaliada a admissão quanto aos pressupostos de admissibilidade analisados na origem, e será avaliada em primeira mão a existência ou não da Repercussão Geral da questão constitucional discutida (...)."

Não restam dúvidas, portanto, que a Repercussão Geral representa um novo requisito intrínseco de admissibilidade dos recursos extraordinários, atuando como um mecanismo de filtragem ao permitir que apenas as teses dotadas de real importância e significado sejam julgadas pelo Supremo Tribunal Federal. Tendo em vista tal finalidade, resta igualmente claro que o exame da Repercussão Geral só deve ser realizado após a análise da presença de todos os demais pressupostos de admissibilidade do recurso extraordinário.

\section{$\underline{\text { 3.2.3 As principais finalidades da Repercussão Geral - declaradas e reais }}$}

\footnotetext{
${ }^{137}$ Cf. op. cit., pp. 54-55.

${ }^{138}$ Cf. op. cit., pp. 176-177.

${ }^{139}$ Para Elvio Ferreira SARTório e FláVIO ChEIM JORGe, o exame da Repercussão Geral deve acontecer "Somente após a prévia avaliação do relator a respeito da presença dos demais requisitos de admissibilidade do Recurso Extraordinário. Num primeiro momento, será preciso averiguar, monocraticamente, se o recurso é admissível ou não, para, na hipótese positiva, posteriormente submeter à turma o debate acerca da Repercussão Geral. Em verdade, seria demasiadamente desgastante ao STF se fizesse de forma diversa; haveria o risco de reconhecer a existência da Repercussão Geral e, posteriormente, não conhecer o recurso no mérito, por ausência de outro requisito de admissibilidade" (Cf. Extraído de J.R.C. TUCCI, op. cit., p. 28). BRUNO DANTAS também é taxativo ao afirmar que "o dispositivo regimental é claro ao fixar que o incidente para verificação da Repercussão Geral se instaurará apenas e tão somente 'quando não for caso de inadmissibilidade do recurso por outra razão', o que significa que o juízo tradicional de admissibilidade o antecederá. Dessa maneira, somos da opinião de que a Repercussão Geral - como pressuposto do cabimento do RE que é - deve ser analisada no contexto da avaliação dos requisitos de admissibilidade desse recurso, sem qualquer precedência sobre os demais pressupostos e requisitos de admissibilidade." (Cf. op. cit., p. 316). No mesmo sentido, leciona EDUARDO TALAMINI que "Então, não apenas por razões de economia processual (o exame da Repercussão Geral em regra depende de quórum qualificado; os demais requisitos podem sempre ser aferidos monocraticamente), mas também por imposição lógica, cabe antes verificar a presença dos demais requisitos de admissibilidade - sobretudo, a presença de uma questão constitucional." (Cf. op. cit., p. 34). Por fim, a lição de ANDRÉ DE AlBUQUERQUE CAVALCANTI ABBUD: "De fato, não seria razoável chamar o colegiado a deliberar sobre a Repercussão Geral de um recurso, para em seguida verificar se ele é intempestivo, deserto, incabível ou carente de qualquer outro pressuposto de admissibilidade, a justificar o simples decreto monocrático de seu não-conhecimento (CPC, art. 557; RISTF, art. 21, § 1 ${ }^{\circ}$; lei $n .8 .038 / 90$, art. 38). Só faz sentido despender tempo e esforços dos demais Ministros da Corte necessários à decisão sobre a Repercussão Geral naqueles recursos que, segundo o juízo do relator, já tenham ultrapassado as demais barreiras a seu conhecimento." (Cf. op. cit., p. 294).
} 
O instituto da Repercussão Geral, idealizado para atuar como um verdadeiro filtro seletor de demandas judiciais, objetiva, precipuamente, a diminuição da quantidade de recursos submetidos à análise e julgamento do Supremo Tribunal Federal.

Sua intenção, portanto, é limitar a jurisdição do STF às questões constitucionais que denotem relevância econômica, política, social ou jurídica, transcendendo os interesses subjetivos das partes litigantes. Além disso, visa, também, à uniformização da interpretação das normas constitucionais, ao passo que evita que múltiplos recursos idênticos, versando sobre a mesma questão constitucional, aportem ao $\mathrm{STF}^{140}$.

Essa diminuição do número de recursos submetidos ao julgamento do Supremo Tribunal Federal provoca outras consequências igualmente benéficas para o aprimoramento do Poder Judiciário brasileiro.

A primeira - e talvez a mais sensível - delas é o aumento da qualidade da prestação jurisdicional outorgada pelo Supremo Tribunal Federal.

Com a instituição da Repercussão Geral, as questões verdadeiramente significativas à nação poderão receber a devida atenção dos Ministros, que a elas poderão dedicar a merecida análise, muito mais profunda e detalhada ${ }^{141-142}$.

É o que EdUARDo TALAMINI chama de "atuação seletiva" do Supremo Tribunal Federal:

"Com o instituto da Repercussão Geral, a atividade do STF no controle incidental de constitucionalidade em sede de recurso extraordinário deve cingir-se a questões revestidas de significativo valor institucional. Instaura-se uma atuação seletiva. Pretende-se que a restrição quantitativa confira ao

\footnotetext{
${ }^{140} \mathrm{Cf}$ Disponível $\quad$ [on $\quad$ line $] \quad$ em www.stf.jus.br/portal/cms/verTexto.asp?servico=jurisprudenciaRepercussaoGeral\&pagina=apresentacao. Acesso em 08 de setembro de 2009.

${ }^{141}$ Estima-se que, no ano de 2007, um Ministro poderia dispensar apenas cerca de quinze minutos de seu tempo para cada processo de sua relatoria; em 2009, esse tempo já havia subido para, aproximadamente, vinte e sete minutos. (Cf. dados extraídos do artigo Mais seletivo e eficiente, publicada pela Revista Veja, edição de 22 de julho de 2009).

${ }^{142}$ Sobre o tema, discorre Taís Schilling Ferraz: "Se é verdade que se reduziram os recursos extraordinários e agravos de instrumento protocolados, autuados e distribuídos no STF - e esta diminuição foi substancial, chegando à casa dos $60 \%$-, cresceu a efetividade da jurisdição constitucional, seja pela quantidade de conflitos individuais solucionados com uma única decisão, seja pela quantidade de temas relevantes que tiveram espaço na pauta do plenário nos últimos anos e que foram avaliados na plenitude.

Esta redução da distribuição, portanto, não significa mera diminuição de carga de processos do Supremo Tribunal Federal, nem implica prejuízo da sua missa jurisdicional ou do acesso individual à Justiça. Releva, isto sim, uma nova forma de prestar jurisdição em matéria constitucional, assegurando às questões de relevância social, política, econômica e jurídica um processo decisório rápido e plural e, na sequência, maior disseminação dos efeitos desta decisão, de forma a garantir a isonomia na aplicação das normas constitucionais." (Cf. op. cit., pp. 105-106).
} 
Supremo Tribunal Federall Tribunal um incremento qualitativo na sua atuação. Em tese, a filtragem propiciará mais tempo e recursos humanos e materiais para a Corte dedicar não só aos recursos extraordinários que versem sobre as questões tidas por relevantes, como também para os demais processos que permanecem em sua esfera de competência. Vale dizer, visa-se a uma qualificação de atividade que vai além do âmbito do recurso extraordinário."

A consequência lógica e natural desse novo cenário que se instaura no Supremo Tribunal Federal é o desempenho de uma função mais assemelhada à de Corte Constitucional, responsável pela guarda, unidade e inteireza do ordenamento jurídico pátrio, como destaca ARRUDA ALVIM:

“O instituto da Repercussão Geral potencializará, no cenário judiciário, a importância do STF, e, paralelamente, o 'dispensará' de pronunciar-se sobre assuntos rotineiros, cujo pronunciamento não se justifica, por inumeráveis argumentos. E, entre outras razões, também não se justifica pelo imenso trabalho carreado aos julgadores, como, ainda, certamente prejudica 0 julgamento de 'casos importantes'. (...) Quando o tribunal vier só a julgar as causas que tenham Repercussão Geral, com este qualificativo definitivamente agregado ao exercício das suas funções, em relação ao recurso extraordinário, conferir-se-lhe-á o perfil correto de que é merecedora esta Corte - e a Nação, enquanto credora de decisões modelo - pela sua posição nos quadros do Poder Judiciário. Desnaturado e desperdiçado mesmo estaria - como esteve - o funcionamento do tribunal, se houvesse de continuar julgando todo e qualquer recurso." 144

Vê-se, assim, que a instituição de um novo filtro seletor de demandas, previsto legislativamente e autorizado pela Magna Carta, tem o condão de alcançar o objetivo ao qual se propõe de forma clara e legítima, sem que seja preciso fazer uso de artifícios interpretativos para afastar da apreciação do Supremo Tribunal Federal temas de menor relevância.

Trata-se, portanto, de um legítimo filtro seletor de demandas, que alcançou a função de fazer com que os demais requisitos de admissibilidade dos recursos extraordinários possam ser correta e restritivamente interpretados.

Sobre o tema, EDUARDO TALAMINI pontua que

"o requisito da Repercussão Geral não supre nem afasta a necessidade de verificação dos demais pressupostos de admissibilidade do recurso. Mas, por um lado, existindo objetivamente tal pressuposto, a Corte está dispensada (aliás, proibida) de criar exigências eminentemente formais para a admissão do

\footnotetext{
${ }^{143}$ Cf. op. cit., p. 25.

${ }^{144}$ Cf. op. cit., pp. 83-84.
} 
recurso, que antes funcionavam como mecanismo velado de filtragem. $\mathrm{O}$ filtro a empregar há de ser apenas o da Repercussão Geral."

No mesmo sentido são as palavras de ANDRÉ DE AlbuQuerQue CAVAlCANTI

ABBUD:

"Até aqui, a necessidade de identificar, dentre a esmagadora quantidade de recursos submetidos ao seu conhecimento, aqueles que mereciam as repousadas atenções da Corte, de acordo com sua missão institucional, acarretava o uso de certos requisitos de admissibilidade, por vezes de forma pouco clara. A despeito de serem pretensamente considerados óbices objetivos ao conhecimento de recursos, pressupostos como o prequestionamento e a ofensa direta acabavam por ter sua 'zona cinzenta' de aplicação explorada pela jurisprudência, de modo a permitir certa seleção dos casos a serem conhecidos pelo tribunal. Essa atitude compunha a chamada 'jurisprudência defensiva' da Corte.

O advento da Repercussão Geral oficializa esse comportamento seletivo, tornando-o algo regulamentado, público e, nessa medida, controlável socialmente. Isso representa sem dúvida, uma vantagem em relação ao sistema anterior e um ganho de qualidade à prestação jurisdicional oferecida nos recursos extraordinários. A aplicação daqueles antigos requisitos em situações questionáveis, às vezes de modo contraditório, torna-se a partir de agora absolutamente desnecessária. O não-conhecimento de recurso em razão de sua pouca relevância será afirmado de forma clara e expressa, com base em argumentos racionais ditados em decisões tornadas públicas." 146

Outro reflexo bastante favorável da adoção de um mecanismo seletor de demandas é a valorização das decisões dos juízes de primeiro grau e dos tribunais locais, que ganharão maior efetividade e credibilidade.

Ao estabelecer mais um requisito intrínseco de admissibilidade aos recursos extraordinários, o legislador pátrio acabou por afastar da competência do Supremo Tribunal Federal milhares de demandas repetitivas e de pequena expressão. Com isso, a solução desses litígios se esgota com a decisão proferida pelo Tribunal local, que passa a ser a sua última Instância recursal $^{147}$.

Isso, certamente, terá o condão de estimular a qualidade das decisões proferidas pelas instâncias inferiores, cientes de que serão, em muitos casos, definitivas e, como tais, precisarão resolver a lide e pacificar o conflito posto a julgamento da forma mais adequada e justa possível.

\footnotetext{
${ }^{145}$ Cf. op. cit., p. 230.

${ }^{146}$ Cf. $O$ anteprojeto de lei sobre a Repercussão Geral dos recursos extraordinários, p. 298.

${ }^{147}$ Ressalvadas as hipóteses de interposição de recurso especial perante o Superior Tribunal de Justiça.
} 
Outros benefícios também foram sentidos com a criação e aplicação prática do instituto da Repercussão Geral.

Um deles foi o estímulo à concretização do ideal de duração razoável do processo, com flagrante economia de atos processuais, maior celeridade na tramitação dos feitos e antecipação do trânsito em julgado das sentenças ${ }^{148}$. Nesse sentido, as palavras de LuIZ GUILHERME MARINONI E DANIEL MITIDIERO:

"No direito brasileiro, a adoção da aferição de Repercussão Geral da controvérsia constitucional discutida no recurso extraordinário e conseguinte eficácia vinculante da decisão a respeito de sua existência ou inexistência contribuem decisivamente para a concretização do direito fundamental ao processo com duração razoável. (...) Há, aí, mais um instrumento para a consecução da unidade do Direito por intermédio da compatibilização das decisões judiciais. Uma vez já decidida a questão, qualquer nova apreciação, sem o fito de revisão da tese, importa dilação indevida no processamento da causa. Com a Repercussão Geral, encurta-se o procedimento, com flagrante economia de atos processuais."149

A restrição das hipóteses de cabimento do recurso extraordinário põe um freio à (aparentemente infinita) insatisfação das partes. Nesse sentido, OSCAR DIAS CORRÊA reflete: “Todas as partes, de um jeito ou de outro, vencidas na segunda instância, pretendem ir ao STF: ou porque não se conformam em perder, e querem, simplesmente, mais um juízo; ou porque consideram que só o julgamento do Supremo Tribunal Federal lhes apazigua a consciência”150.

Dessa forma, com a antecipação do trânsito em julgado das sentenças, ficam reforçados os ideais de certeza e segurança jurídica, uma vez que os conflitos são muito mais rápida e definitivamente pacificados, inclusive com decisões de melhor qualidade, proferidas pelos juízes de Primeiro e Segundo Graus. E tudo isso sem falar na sensível economia processual, com a diminuição da quantidade de recursos que aportam, diariamente, ao Supremo Tribunal Federal.

\footnotetext{
${ }^{148}$ No mesmo sentido, pontua Ulisses Schwarz Viana: "A Repercussão Geral, como objetivação do recurso extraordinário, será novo programa condicional (procedimento) eficaz na garantia do acesso à Justiça, célere e dotado de segurança, dando efetividade ao art. $5^{\circ}$, LXXVIII, da CF, acrescido pela EC n. 45/2004, segundo o qual: a todos, no âmbito judicial e administrativo, são assegurados a razoável duração do processo e os meios que garantam a celeridade de sua tramitação. Em síntese, a função sistêmica primária observável na Repercussão Geral reside em que a decisão em um único recurso produzirá eficácia erga omnes e efeito vinculante aos casos que tenham por objeto o mesmo tema constitucional (objetivo) e que, consequentemente, tornará a prestação jurisdicional constitucional mais célere, como resultado da diminuição dos processos que chegarão até o Supremo Tribunal Federal e das demandas múltiplas nos demais graus de jurisdição." (Cf. op. cit., p. 207).

${ }^{149}$ Cf. op. cit., pp. 32-33.

${ }^{150}$ Cf. O Supremo Tribunal Federal, corte constitucional do Brasil, p. 51.
} 
Isso também faz com que o recurso extraordinário deixe de ser visto como mais uma via processual para se buscar prestações jurisdicionais de cunho meramente individual. Deve ser garantida ao Supremo Tribunal Federal a possibilidade de analisar e julgar apenas as questões que denotem efetiva importância, de modo que tenha a liberdade - e o tempo necessários para desempenhar um papel mais adequado à função de Corte Constitucional, sem ter de se ocupar da dissolução de litígios individuais e restritos.

Por fim, insta ressaltar a correlação entre o instituto da Repercussão Geral da questão constitucional e das súmulas vinculantes.

Por serem reconhecidas como relevantes, do ponto de vista econômico, social, político ou jurídico, aptas a repercutirem efeitos para além dos interesses subjetivos em litígio, não raro se extraem das questões constitucionais dotadas de Repercussão Geral os enunciados que irão vincular a atuação dos demais órgãos jurisdicionais.

É o caso, por exemplo, da Súmula Vinculante $\mathrm{n}^{\circ} 12$, extraída do julgamento do RE no 567.801, cuja Repercussão Geral foi reconhecida em 06.03.2008¹51, e da Súmula Vinculante $n^{\circ} 13$, extraída do julgamento do RE $n^{\circ} 579.951$, cuja Repercussão Geral foi reconhecida em 10.04.2008 ${ }^{152}$.

Sobre o tema, destaca RodOLFO DE CAMARGO MANCUSO:

"Esse fenômeno se deve a que a emissão da súmula vinculante condiciona-se à existência de 'reiteradas decisões em matéria constitucional', capaz, além disso, de acarretar 'grave insegurança jurídica e relevante multiplicação de processos sobre questão idêntica', contexto que, justamente, está presente nos RE's massivos e repetitivos, suscetíveis de manejo por amostragem no tocante à aferição da Repercussão Geral (CPC, arts. 543-A e B)." 153

Vê-se, então que, com a obrigatoriedade da Repercussão Geral, enquanto requisito formal de admissibilidade do recurso extraordinário, há uma clara racionalização da atividade jurisdicional brasileira.

\footnotetext{
${ }^{151}$ Súmula vinculante $\mathrm{n}^{\circ}$ 12: "A cobrança de taxa de matrícula nas universidades públicas viola o disposto no art. 206, IV, da Constituição Federal”. Precedentes: RE 500171, RE 542422, RE 536744, RE 536754, RE 526512, RE 543163, RE 510378, RE 542594, RE 510735, RE 511222, RE 542646, RE 562779.

${ }^{152}$ Súmula vinculante $\mathrm{n}^{\circ} 13$ : "A nomeação de cônjuge, companheiro ou parente em linha reta, colateral ou por afinidade, até o terceiro grau, inclusive, da autoridade nomeante ou de servidor da mesma pessoa jurídica investido em cargo de direção, chefia ou assessoramento, para o exercício de cargo em comissão ou de confiança ou, ainda, de função gratificada na administração pública direta e indireta em qualquer dos Poderes da União, dos Estados, do Distrito Federal e dos Municípios, compreendido o ajuste mediante designações recíprocas, viola a Constituição Federal". Precedentes: ADI 1521 MC, MS 23780, ADC 12 MC, ADC 12 (acórdão pendente de publicação), RE 579951.

${ }^{153}$ Cf. op. cit., pp. 193-194.
} 


\section{$\underline{3.3 \text { Os aspectos práticos }}$}

$\underline{\text { 3.3.1 A presunção absoluta prevista pelo artigo 543-A, } \S 3^{\circ} \text {, do Código de }}$ Processo Civil

Nos termos do artigo 543-A, $\S 3^{\circ}$, do Código de Processo Civil, "haverá Repercussão Geral sempre que o recurso impugnar decisão contrária a súmula ou jurisprudência dominante do Tribunal”.

Trata-se, como já dito em linhas anteriores, de uma hipótese de presunção absoluta da existência de Repercussão Geral, que revela a preocupação do legislador infraconstitucional com a segurança jurídica e com a função uniformizadora do recurso extraordinário: será relevante o recurso extraordinário que impugnar decisão contrária à súmula ou jurisprudência dominante do Supremo Tribunal Federal ${ }^{154}$.

Trata-se de uma hipótese objetiva, dotada de manifesta e inquestionável relevância jurídica. Nas palavras de JosÉ RoGÉRIO CRUZ E TUCCI:

"Se a decisão impugnada afrontar súmula do Supremo Tribunal Federal, esta tarefa descortina-se bem mais simplificada, dada a presunção legal já apontada (art. 543-A, § $3^{\circ}$ ). Demandará, pelo contrário, maior cuidado do recorrente a demonstração de ter o acórdão recorrido contrariado jurisprudência dominante. É certo que os precedentes invocados pelo recorrente deverão ser atuais e intrinsecamente análogos à tese que alicerça o Recurso Extraordinário"155.

Para a caracterização da hipótese prevista nesse dispositivo legal, basta que a decisão recorrida seja contrária à jurisprudência dominante do Supremo Tribunal Federal, ou mesmo simples súmula, não necessariamente as vinculantes ${ }^{156}$. Isso porque, como bem

\footnotetext{
${ }^{154}$ A esse respeito, pontua Bruno Dantas: “(...) a mera divergência entre a decisão recorrida e a jurisprudência predominante é suficiente para causar impacto indireto em toda a sociedade brasileira, pois: i) ou a decisão recorrida está equivocada, e precisa ser ajustada ao entendimento prevalecente no STF; ou ii) houve substancial modificação no quadro fático e jurídico, ou mesmo alteração na compreensão e no convencimento dos ministros sobre o assunto, e é a jurisprudência do STF que merece ser alterada, para se ajustar ao novo cenário." (Cf. op. cit., p. 301). Também sobre o tema, João Francisco Naves da Fonseca: "Propositalmente o legislador lançou mão de conceitos jurídicos indeterminados, para evitar o equívoco de enumerar casuisticamente todas as hipóteses em que haveria Repercussão Geral, e deixou esta presumida se o recurso extraordinário impugnar decisão contrária à súmula ou jurisprudência dominante do Supremo Tribunal Federal (art. 543-A, $\S 3^{\circ}$ )." (Cf. Exame dos fatos nos recursos extraordinário e especial, p. 63).

${ }^{155}$ Cf. op. cit., pp. 26 e 27.

${ }^{156}$ A esse respeito, importa notar a pertinente ressalva destacada por Eduardo Talamini: "Lembre-se apenas que há súmulas (não vinculantes) do STF que não versam sobre questões constitucionais. Remontam à época em que o Tribunal tinha a competência recursal extraordinária também para questões de lei federal ou são recentes, mas foram formadas a partir do entendimento sedimentado em atividade alheia à tutela da Constituição.
} 
destaca HUMBERTO THEODORO JÚNIOR, “A súmula, in casu, não precisa ser a vinculante, mas apenas a que retrate jurisprudência assentada, pois, mesmo sem súmula, a Repercussão Geral estará configurada em qualquer julgamento que afronte 'jurisprudência dominante' do STF"157.

Ademais, vale notar que também se presume a Repercussão Geral quando a decisão recorrida está em confronto com decisões do Plenário do STF revestidas de força vinculante, como, por exemplo, decisões proferidas em sede de ações diretas de inconstitucionalidade e constitucionalidade, em arguições de descumprimento de preceitos fundamentais, entre outras ${ }^{158}$.

Caracterizada a contrariedade entre a decisão recorrida e a jurisprudência predominante do Supremo Tribunal Federal - e, consequentemente, reconhecida a Repercussão Geral - abrem-se aos Ministros dois caminhos: (i) confirmar o entendimento já consolidado e, em consequência, dar imediato provimento ao recurso extraordinário, ou (ii) indicar que pretende reformar a posição até então assentada e, então, determinar a distribuição do recurso extraordinário, cujo mérito será regularmente julgado.

Na precisa síntese de RICARDO DE BARROS LEONEL:

"O desenvolvimento dessa situação tenderá, entre duas hipóteses, a uma: a) ou se confirma, em novos casos, a posição sumulada anteriormente ou a jurisprudência dominante, e a tendência do STF será editar súmula vinculante na matéria; ou b) o STF poderá rever sua posição anterior, inclusive com cancelamento de súmulas, o que é perfeitamente admissível; aliás, é natural mesmo que isso ocorra, decorrendo da evolução social e política, que pode e deve se refletir na interpretação e concretização do direito constitucional." 159

Assim, o Supremo Tribunal Federal estabeleceu - quando do julgamento da Questão de Ordem no Recurso Extraordinário n ${ }^{\circ}$ 579. 431 - um procedimento especial, segundo o qual o Presidente do STF, antes mesmo da distribuição do recurso extraordinário, suscitará Questão de Ordem e levará a matéria ao julgamento do Plenário, que poderá confirmar a jurisprudência dominante (e dar imediato provimento ao recurso) ou indicar que

Obviamente, a divergência entre a decisão recorrida e a tese enunciada em tais súmulas será irrelevante para os fins do instituto em exame: nesses casos, não se terá uma questão constitucional." (Cf. op. cit., p. 47).

${ }^{157}$ Cf. op. cit., p. 104.

${ }^{158}$ Nas palavras de Eduardo Talamini: "Nessas hipóteses, o entendimento estabelecido em quorum qualificado também tem valor no mínimo equivalente ao de jurisprudência dominante." (Cf. op. cit., p. 48).

${ }^{159}$ Cf. op. cit., p. 174. 
pretende reformar seu entendimento (e determinar a distribuição do recurso, para julgamento pelas vias ordinárias) ${ }^{160}$.

Conclui-se, portanto, que o disposto no artigo 543-A, § $3^{\circ}$, do Código de Processo Civil reforça, expressamente, a função uniformizadora da jurisprudência exercida pelo Supremo Tribunal Federal, por consignar, inequivocamente, a relevância de seus precedentes, cuja contrariedade, por si só, se reveste de importância geral à sociedade, ultrapassando os interesses subjetivos das partes litigantes.

3.3.2 A presunção relativa prevista pelo artigo 324 , parágrafo $1^{\circ}$, do Regimento Interno do Supremo Tribunal Federal: a hipótese de reconhecimento tácito da Repercussão Geral

O artigo 324, parágrafo $1^{\circ}$, do Regimento Interno do Supremo Tribunal Federal instituiu uma hipótese de presunção relativa da presença de Repercussão Geral ao prever a possibilidade de reconhecimento tácito de sua existência ${ }^{161}$.

O referido dispositivo determina que, recebida a manifestação do Relator, por meio eletrônico, acerca da presença de Repercussão Geral, os demais Ministros terão o prazo

160 “1. Aplica-se, plenamente, o regime da Repercussão Geral às questões constitucionais já decididas pelo Supremo Tribunal Federal, cujos julgados sucessivos ensejaram a formação de súmula ou jurisprudência dominante.

2. Há, nessas hipóteses, necessidade de pronunciamento expresso do Plenário desta Corte sobre a incidência dos efeitos da Repercussão Geral reconhecida para que, nas instâncias de origem, possam ser aplicadas as regras do novo regime, em especial, para fins de retratação ou declaração de prejudicialidade dos recursos sobre o mesmo tema (CPC, art. 543-B, § $3^{\circ}$ ).

Fica, nesse sentido, aprovada a proposta de adoção de procedimento específico que autorize a Presidência da Corte a trazer ao Plenário, antes da distribuição do RE, questão de ordem na qual poderá ser reconhecida a Repercussão Geral da matéria tratada, caso atendidos os pressupostos de relevância. Em seguida, o Tribunal poderá, quanto ao mérito, (a) manifestar-se pela subsistência do entendimento já consolidado ou (b) deliberar pela renovação da discussão do tema.

Na primeira hipótese, fica a Presidência autorizada a negar distribuição e a devolver á origem todos os feitos idênticos que chegarem ao STF, para a adoção, pelos órgãos judiciários a quo, dos procedimentos previstos no art. 543-B, § $3^{\circ}$, do CPC.

Na segunda situação, o feito deverá ser encaminhado à normal distribuição para que, futuramente, tenha o seu mérito submetido ao crivo do Plenário.” (Cf. RE 579. 431 QO, rel. Min. Gilmar Mendes, j. em 13.03.2008).

161 "Art. 324. Recebida a manifestação do(a) Relator(a), os demais ministros encaminhar-lhe-ão, também por meio eletrônico, no prazo comum de 20 (vinte) dias, manifestação sobre a questão de Repercussão Geral.

$\S 1^{\circ}$ Decorrido o prazo sem manifestações suficientes para a recusa do recurso, reputar-se-á existente a Repercussão Geral.

$\S 2^{\circ}$ Não incide o disposto no parágrafo anterior quando o Relator declare que a matéria é infraconstitucional, caso em que a ausência de pronunciamento no prazo será considerada como manifestação de inexistência de Repercussão Geral, autorizando a aplicação do art. 543-A, § 5º do Código de Processo Civil, se alcançada a maioria de dois terços de seus membros."

$\S 3^{\circ} \mathrm{O}$ recurso extraordinário será redistribuído por exclusão do(a) Relator(a) e dos ministros que expressamente o(a) acompanharam nos casos em que ficarem vencidos." 
de 20 (vinte) dias para se pronunciar sobre o tema. Decorrido o prazo assinalado sem manifestações suficientes para a recusa, reputar-se-á existente a Repercussão Geral.

A exceção a essa regra vem insculpida no parágrafo $2^{\circ}$ do art. 324 do RISTF: caso a manifestação do Relator seja no sentido de que a matéria tratada no recurso extraordinário é infraconstitucional, eventual inércia dos demais Ministros deverá ser interpretada como manifestação pela ausência de Repercussão Geral - e tal decisão repercutirá para todos os recursos que versem sobre a mesma matéria, nos termos do art. 543-A, parágrafo $5^{\circ}$, do Código de Processo Civil.

Muitas críticas dão conta de que a realização desse julgamento por meio eletrônico e a inexistência de debates entre os Ministros ou de sustentação oral pelas partes violaria o princípio do contraditório. Há quem defenda, ainda, que o prazo de vinte dias seria demasiadamente exíguo e comprometeria a análise cuidadosa do processo e a qualidade dos julgamentos.

A despeito das opiniões em sentido contrário, não se pode ignorar que a Reforma do Judiciário passa, necessariamente, pela adoção de meios eletrônicos de comunicação e tramitação dos processos, cada vez em mais larga escala ${ }^{162}$.

Não parece absurdo dar preferência à celeridade e à efetividade da prestação jurisdicional, em detrimento de debates e sustentações orais. O julgamento acerca da existência da Repercussão Geral através de um Plenário Virtual não tem, por si só, o condão de mitigar os relevantes valores do contraditório; apenas limita a manifestação das partes litigantes a um momento imediatamente anterior, qual seja, o da decisão pelo órgão colegiado a quo.

É preciso ter em mente que o intuito principal do mecanismo seletor de demandas é otimizar a atividade judicial como um todo, através da diminuição do número de recursos submetidos ao julgamento do Supremo Tribunal Federal. Como já explanado anteriormente, o

\footnotetext{
${ }^{162}$ Nesse sentido, "A partir de agora, 27 tribunais do país estão aptos a remeter eletronicamente os processos que serão julgados pelo Superior Tribunal de Justiça (STJ). Dentre eles, o Tribunal de Justiça do Estado do Tocantins, que aderiu ao Projeto Justiça Virtual. A iniciativa dará maior velocidade à tramitação dos casos (...). Em solenidade no STJ, ao lado do ministro Gilmar Mendes, o presidente do Supremo Tribunal Federal, o ministro Cesar Rocha ressaltou que a economia em dinheiro também será significativa. "Nós pagamos por ano cerca de $R \$ 20$ milhões aos correios apenas para a remessa e retorno de processos entre os estados e o STJ." (Cf. Judiciário adota tecnologia para o combate à morosidade. Disponível $\left[\begin{array}{ll}\text { lone }\end{array}\right.$ em http://www.jusbrasil.com.br/noticias/1845035/judiciario-adota-tecnologia-para-o-combate-a-morosidade. Acesso em 11 de setembro de 2009).

Ainda, a Lei n ${ }^{\circ} 11.419 / 2006$, que dispõe sobre a informatização do processo judicial, e a Resolução no $344 / 2007$ do STF, que regulamentou o uso do meio eletrônico de tramitação de processos judiciais, comunicação dos atos, transmissão de peças processuais e procedimento para recebimento de Recursos Extraordinários em formato digital. Disponível [on line] em http://www.stf.jus.br/ARQUIVO/NORMA/RESOLUCAO344-2007.PDF. Acesso em 29 de julho de 2009.
} 
STF deve ater-se à análise de questões que denotem efetiva relevância para o País, de modo que quanto menos tempo perder com aspectos burocráticos e formalistas, melhor ${ }^{163}$.

Sendo assim, parece temeroso insistir-se na necessidade de observância a todas as garantias processuais previstas pelo nosso ordenamento. É preciso sopesá-las e, em dados momentos, preterir algumas delas para que possa garantir a rapidez e a eficiência do julgamento de questões verdadeiramente importantes para a nação.

\section{$\underline{\text { 3.3.3 A intervenção do amicus curiae para o reconhecimento da Repercussão }}$} $\underline{\text { Geral }}$

Através do art. 543-A, parágrafo $6^{\circ}$, do Código de Processo Civil, o legislador brasileiro admitiu, expressamente, a possibilidade de intervenção de terceiros no processo de aferição da existência de Repercussão Geral.

Esse dispositivo, como se vê, permite a manifestação de terceiros - assim entendidos como "todo aquele que não pede ou em face de quem não se pede a prestação da tutela jurisdicional" 164 - que poderiam ser afetados, de alguma forma, pelos efeitos da decisão acerca da Repercussão Geral.

Isso porque, como já dito em linhas anteriores, a decisão do Supremo Tribunal Federal a respeito da existência de Repercussão Geral em um dado caso concreto é paradigmática e, nos termos do art. 543-A, parágrafo $5^{\circ}$, do Código de Processo Civil, igualmente aplicável a todos os recursos que versem sobre idêntica matéria ${ }^{165}$.

Contudo, ainda que admitida a possibilidade da intervenção de terceiros no procedimento de reconhecimento da Repercussão Geral, é preciso destacar que apenas a modalidade de amicus curiae se mostra adequada.

Segundo FREDIE SOUZA DIDIER JÚNIOR, o amicus curiae é um perito em matéria de direito, um auxiliar do juízo; para o Supremo Tribunal Federal, é instrumento apto a democratizar a discussão sobre relevante matéria constitucional, pois visa a ampliar o debate das questões suscitadas. Nos dizeres de EdUARdo TALAMINI, "alguém que é admitido no processo para fornecer subsídios para a solução da questão, sem, no entanto, passar a

\footnotetext{
${ }^{163}$ Um excelente exemplo disso é a flexibilização trazida pelo $\S 4^{\circ}$ do artigo 543-A do Código de Processo Civil, que dispensa a remessa do recurso ao Plenário da Corte caso quatro Ministros se manifestem, previamente, pelo reconhecimento da Repercussão Geral.

${ }^{164}$ Cf. leciona Cássio Scarpinella Bueno, Amicus Curiae no processo civil brasileiro: um terceiro enigmático, $\mathrm{p}$. 359.

165 “§ $5^{\circ}$ Negada a existência da Repercussão Geral, a decisão valerá para todos os recursos sobre matéria idêntica, que serão indeferidos liminarmente, salvo revisão da tese, tudo nos termos do Regimento Interno do Supremo Tribunal Federal."
} 
titularizar posições subjetivas relativas às partes". ${ }^{166}$ Até mesmo o Dicionário Jurídico Black's define o amicus curiae como alguém com forte interesse na questão, ou em aspectos da questão, discutida em uma demanda, mas que dela não faz parte ${ }^{167}$.

A intervenção do amicus curiae está prevista pela Lei no 6.385/1976 (art. 31) ${ }^{168}$,

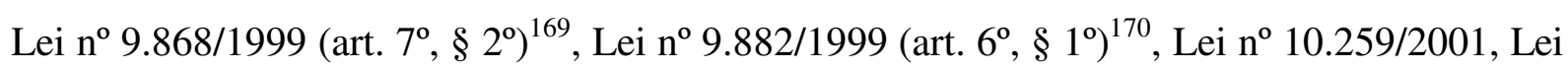
$\mathrm{n}^{\mathrm{o}} 11.417 / 2006$ (art. $\left.2^{\mathrm{o}}, \S 2^{\circ}\right)^{171}$, além da previsão contida no Código de Processo Civil, em seu artigo $482, \S 3^{\mathrm{o}^{172}}$ e no Regimento Interno do STF, em seus artigos $131, \S 3^{\mathrm{o} 173}$ e $323, \S$ $3^{\text {o174 }}$, entre outros diplomas legais.

${ }^{166}$ Cf. Novos aspectos da jurisdição constitucional brasileira: Repercussão Geral, força vinculante, modulação
dos efeitos do controle de constitucionalidade e alargamento do objeto do controle direto, p. 61 .
${ }_{167}$ Tradução livre. No original: “a person with strong interest in or views on the subject matter of an action, but
not a party to the action" (Cf. Black's Law Dictionary, p. 82).
168 "Art. 31 - Nos processos judiciários que tenham por objetivo matéria incluída na competência da Comissão de
Valores Mobiliários, será esta sempre intimada para, querendo, oferecer parecer ou prestar esclarecimentos, no
prazo de quinze dias a contar da intimação.
$\S 1^{\circ}$ - A intimação far-se-á, logo após a contestação, por mandado ou por carta com aviso de recebimento,
conforme a Comissão tenha, ou não, sede ou representação na comarca em que tenha sido proposta a ação.
$\S 2^{\circ}$ - Se a Comissão oferecer parecer ou prestar esclarecimentos, será intimada de todos os atos processuais
subseqüentes, pelo jornal oficial que publica expedientes forense ou por carta com aviso de recebimento, nos
termos do parágrafo anterior.
$\S 3^{\circ}$ - A comissão é atribuída legitimidade para interpor recursos, quando as partes não o fizeram.
$\S 4^{\circ}$ - O prazo para os efeitos do parágrafo anterior começará a correr, independentemente de nova intimação, no
dia imediato aquele em que findar o das partes." (grifos nossos).
169 "Art. $7^{\circ}$ Não se admitirá intervenção de terceiros no processo de ação direta de inconstitucionalidade.
(...) $\S 2^{\underline{0}}$ O relator, considerando a relevância da matéria e a representatividade dos postulantes, poderá, por despacho irrecorrível, admitir, observado o prazo fixado no parágrafo anterior, a manifestação de outros órgãos ou entidades." (grifos nossos).

170 "Art. $6^{\underline{0}}$ Apreciado o pedido de liminar, o relator solicitará as informações às autoridades responsáveis pela prática do ato questionado, no prazo de dez dias.

$\S 1^{\circ} \underline{\text { Se entender necessário, poderá o relator ouvir as partes nos processos que ensejaram a argüição, requisitar }}$ informações adicionais, designar perito ou comissão de peritos para que emita parecer sobre a questão, ou ainda, fixar data para declarações, em audiência pública, de pessoas com experiência e autoridade na matéria.

$\S 2^{0}$ Poderão ser autorizadas, a critério do relator, sustentação oral e juntada de memoriais, por requerimento dos interessados no processo." (grifos nossos).

171 "Art. $2^{\underline{0}}$ O Supremo Tribunal Federal poderá, de ofício ou por provocação, após reiteradas decisões sobre matéria constitucional, editar enunciado de súmula que, a partir de sua publicação na imprensa oficial, terá efeito vinculante em relação aos demais órgãos do Poder Judiciário e à administração pública direta e indireta, nas esferas federal, estadual e municipal, bem como proceder à sua revisão ou cancelamento, na forma prevista nesta Lei.

$\S 1^{\circ}$ O enunciado da súmula terá por objeto a validade, a interpretação e a eficácia de normas determinadas, acerca das quais haja, entre órgãos judiciários ou entre esses e a administração pública, controvérsia atual que acarrete grave insegurança jurídica e relevante multiplicação de processos sobre idêntica questão.

$\S 2^{\underline{0}}$ O Procurador-Geral da República, nas propostas que não houver formulado, manifestar-se-á previamente à edição, revisão ou cancelamento de enunciado de súmula vinculante.

$\S 3^{0}$ A edição, a revisão e o cancelamento de enunciado de súmula com efeito vinculante dependerão de decisão tomada por 2/3 (dois terços) dos membros do Supremo Tribunal Federal, em sessão plenária.

$\S 4^{\circ}$ No prazo de 10 (dez) dias após a sessão em que editar, rever ou cancelar enunciado de súmula com efeito vinculante, o Supremo Tribunal Federal fará publicar, em seção especial do Diário da Justiça e do Diário Oficial da União, o enunciado respectivo." (grifos nossos).

172 "Art. 482. Remetida a cópia do acórdão a todos os juízes, o presidente do tribunal designará a sessão de julgamento. 
Sua participação é permitida a entidades, órgãos e organizações não governamentais de defesa das liberdades civis, bem como a qualquer outro ente que demonstre ter interesse na solução da controvérsia, seja na demanda individualmente considerada, seja em razão dos efeitos que a decisão do Supremo Tribunal Federal é capaz de provocar.

Nesse sentido, os dizeres de José Miguel Garcia Medina:

"Na medida em que os problemas jurídicos interessam não apenas às partes, mas a uma parcela mais ampla da sociedade, ou a toda a sociedade, deve o sistema possibilitar a participação de terceiros que, de modo representativo, possam expor, no processo, o ponto de vista das esferas individuais ou dos grupos afetados. (...) à sociedade devem ser assegurados instrumentos de participação no procedimento, a fim de que possam informar-se, analisar as opções que no processo são colocadas, indicar suas objeções a que uma ou outra solução seja escolhida, e ter suas objeções analisadas pelo Poder Judiciário." 175

Também seguindo esse raciocínio, a ressalva de EDUARDO TALAMINI:

“(...) além de órgãos e entidades que demonstrem objetivamente sua qualificação para participar (como o fariam nos processos de controle abstrato), também aqueles que comprovarem a condição de parte em outros processos

$\S 1^{\circ} \mathrm{O}$ Ministério Público e as pessoas jurídicas de direito público responsáveis pela edição do ato questionado, se assim o requererem, poderão manifestar-se no incidente de inconstitucionalidade, observados os prazos e condições fixados no Regimento Interno do Tribunal.

$\S 2^{\circ}$ Os titulares do direito de propositura referidos no art. 103 da Constituição poderão manifestar-se, por escrito, sobre a questão constitucional objeto de apreciação pelo órgão especial ou pelo Pleno do Tribunal, no prazo fixado em Regimento, sendo-lhes assegurado o direito de apresentar memoriais ou de pedir a juntada de documentos.

$\S 3^{\circ} \mathrm{O}$ relator, considerando a relevância da matéria e a representatividade dos postulantes, poderá admitir, por despacho irrecorrível, a manifestação de outros órgãos ou entidades." (grifos nossos).

173 “Art. 131. Nos julgamentos, o Presidente do Plenário ou da Turma, feito o relatório, dará a palavra, sucessivamente, ao autor, recorrente, peticionário ou impetrante, e ao réu, recorrido ou impetrado, para sustentação oral.

$\S 1^{\circ} \mathrm{O}$ assistente somente poderá produzir sustentação oral quando já admitido.

$\S 2^{\circ}$ Não haverá sustentação oral nos julgamentos de agravo, embargos declaratórios, arguição de suspeição e medida cautelar.

$\S \underline{3^{\circ} \text { Admitida a intervenção de terceiros no processo de controle concentrado de constitucionalidade, fica-lhes }}$ facultado produzir sustentação oral, aplicando-se, quando for o caso, a regra do $\S 2^{\circ}$ do art. 132 deste Regimento. $\S 4^{\circ}$ No julgamento conjunto de causas ou recursos sobre questão idêntica, a sustentação oral por mais de um advogado obedecerá ao disposto no $\S 2^{\circ}$ do art. 132." (grifos nossos).

174 “Art. 323. Quando não for caso de inadmissibilidade do recurso por outra razão, o(a) Relator(a) ou o Presidente submeterá, por meio eletrônico, aos demais Ministros, cópia de sua manifestação sobre a existência, ou não, de Repercussão Geral.(...)

$\S 3^{\circ}$ Mediante decisão irrecorrível, poderá o(a) Relator(a) admitir de ofício ou a requerimento, em prazo que fixar, a manifestação de terceiros, subscrita por procurador habilitado, sobre a questão da Repercussão Geral." (grifos nossos).

${ }^{175}$ Cf. op.cit., p 345. 
que tratam da mesma questão podem ser admitidos como colaboradores da Corte, desde que demonstrem que podem ter algum argumento útil, algum subsídio relevante para acrescentar à discussão já instaurada."

O interesse do amicus curiae na aferição da Repercussão Geral não se confunde com o interesse processual tradicionalmente concebido; ao contrário, sua atuação reveste-se do chamado interesse público, institucional, em municiar o Supremo Tribunal Federal de dados e informações relevantes, capazes de influenciar e auxiliar o processo de tomada de decisão pela Corte.

Essa modalidade de intervenção permite que o "amigo da Corte" passe a integrar a demanda, com o intuito de auxiliar o magistrado na análise da presença de Repercussão Geral, fornecendo informações e subsídios capazes de demonstrar a relevância e a transcendência da questão posta em discussão.

É importante ressaltar, de outro lado, que a intervenção do amicus curiae também é admitida para que seja afastada a Repercussão Geral de determinada questão constitucional; sua atuação, portanto, pode ser favorável ou desfavorável à admissão do recurso extraordinário $^{177}$.

Nesse sentido, a lição de CÁSSIO SCARPINELlA BUENO:

"Acreditamos que é justamente nesses casos, em que o legislador empregou a técnica das normas jurídicas abertas, que o amicus poderá ser aquele que fornece ao magistrado valores e esclarecimentos que possam ser uteis para auxiliá-lo a construir o tipo jurídico. Sobretudo, vale a pena frisar, quando o resultado dessa 'construção' passa, gradativamente (inclusive, mais recentemente, para a nossa própria experiência jurídica), a dizer respeito a outros que não os litigantes do específico caso julgado, a 'terceiros', portanto." 178

Como visto, a vagueza da norma jurídica instituidora da Repercussão Geral faz com que a intervenção do amicus curiae seja admitida - e, mais, seja favorável e benéfica ao próprio sistema -, na medida em que dota os julgadores de outros elementos e informações

\footnotetext{
${ }^{176}$ Cf. op.cit., p. 62.

${ }^{177}$ Sobre essa liberdade de atuação do amicus curiae, lecionam Luis Guilherme Marinoni e Daniel Mitidiero: "Uma vez admitida a sua participação, subscrita por advogado, poderá ofertar razões por escrito afim de convencer o Supremo Tribunal Federal da existência ou inexistência de Repercussão Geral a partir do caso concreto. Note-se o ponto: a participação de terceiros pode orientar-se tanto no sentido da admissão como no da inadmissão do recurso extraordinário relativamente à Repercussão Geral da controvérsia constitucional ali debatida". (Cf. Repercussão Geral no recurso extraordinário, p. 48).

${ }^{178}$ Cf. op.cit., p. 38.
} 
(jurídicos e, até mesmo, fáticos) capazes de elucidar o alcance que a discussão da questão posta em exame é capaz de alcançar.

A importância dessa intervenção ganha especial relevo quando se tem em mente que a decisão proferida pelo Supremo Tribunal Federal tem caráter vinculante a todos os demais recursos assemelhados, de modo que a negativa de existência de Repercussão Geral em um determinado caso concreto acaba por impedir a apreciação da Corte sobre a matéria veiculada.

Nesse sentido, é a lição de EDUARDO TALAMINI:

"Essa regra é de todo justificável quando se considera que a definição do incidente é apta a ter relevância que vai além do processo em que proferida. Por um lado, reitere-se, o juízo do Plenário sobre a existência ou não da Repercussão Geral será diretamente aplicável a outros recursos com idêntico objeto. Por outro, se a questão tem Repercussão Geral sob o aspecto qualitativo antes indicado, justifica-se que determinados entes proponham-se a contribuir na sua demonstração, tendo em vista a importância da matéria para os alicerces e desígnios do Estado." $" 179$

Desenvolvendo raciocínio semelhante, afirma BRUNO DANTAS:

"Efetivamente, o problema da Repercussão Geral reúne, a um só tempo, duas questões muito bem explanadas por Cássio Scarpinella Bueno: i) trata-se (...) de conceito jurídico indeterminado, que carece, em certa medida, de preenchimento valorativo; e ii) a disposição expressa constante do $\S 5^{\circ}$ do art. 543-A do CPC dá o tom do impacto que o julgamento paradigmático assumirá na vida de terceiros."

Como um dos mais emblemáticos exemplos da atuação de amicus curiae no reconhecimento da Repercussão Geral, é possível citar a participação do recorrente que viu o processamento de seu recurso extraordinário sobrestado - nos termos do art. 543-B, caput, do CPC, em razão da seleção de recurso paradigma fundado em idêntica controvérsia - na arguição de subsídios e outros argumentos capazes de reforçar a Repercussão Geral da questão tratada, no bojo do recurso selecionado pelo Supremo Tribunal Federal.

A importância da participação do amicus curiae no processo de julgamento da Repercussão Geral justificou a previsão, pelo próprio Supremo Tribunal Federal, da possibilidade de sua requisição de ofício, mesmo quando não tenha havido a manifestação espontânea de participação de algum interessado.

\footnotetext{
${ }^{179}$ Cf. op.cit., p. 61.

${ }^{180}$ Cf. op.cit., p. 321.
} 
Assim, nos termos do art. 323, parágrafo $3^{\circ}$, do Regimento Interno do Supremo Tribunal Federal, a intervenção do amicus curiae pode ser espontaneamente deflagrada pelo interessado ou até mesmo requerida, de ofício, pelo $\mathrm{STF}^{181}$.

A requisição, de ofício, da participação de terceiro no exame da Repercussão Geral poderá assumir uma de duas formas cabíveis, explicitamente indicadas na decisão que a determinar: (i) através de um convite, sem qualquer prejuízo ao terceiro em caso de não aceitação, ou (ii) através de uma convocação, estabelecendo ao terceiro o dever de se manifestar, ainda que entenda não possuir subsídios úteis ou suficientes ao deslinde da causa.

Nesse sentido, a lição de EDUARDO TALAMINI:

"Tal regra é consentânea com a natureza da intervenção do terceiro. Se o papel do amicus curiae é colaborar com o Tribunal com subsídios úteis para a solução da causa ou de um incidente, é razoável que o próprio STF solicite esse auxílio. A solicitação pode se dar de duas formas: (i) como mero convite ao terceiro para, querendo, manifestar-se ou (ii) como requisição para que apresente subsídios ou informações que detém. Deve ficar claro, na decisão do relator, sob qual das duas modalidades está sendo feita a chamada de terceiros. No primeiro caso, quando muito, tem-se um mero ônus: o prejuízo da nãoparticipação será do próprio terceiro, que deixará de contribuir na busca para a consecução do resultado que lhe pareça o mais adequado (e muitas vezes o interessa juridicamente). $\mathrm{Na}$ segunda hipótese, configura-se um dever, expressão do dever geral de colaborar com a Justiça (CPC, art. 341, I): o terceiro terá de atender à convocação, ainda que para indicar que não dispõe de subsídios relevantes para a causa. Essa segunda modalidade tende a ser mais rara, mas não pode ser descartada."182

Outro ponto que merece especial destaque é a irrecorribilidade da decisão que admite a intervenção do amicus curiae, nos termos do dispositivo legal acima transcrito.

Essa vedação recursal imposta pelo próprio Supremo Tribunal Federal também está presente na disciplina legal do amicus curiae em outros procedimentos, como nas já citadas Lei ${ }^{\circ}$ 9.868/1999 ( $\operatorname{art} 7^{\circ}, \S 2^{\circ}$ ), no Código de Processo Civil, em seu artigo 482, § $3^{\circ}$ e Lei $\mathrm{n}^{\mathrm{o}} 11.417 / 2006\left(\operatorname{art} .2^{\circ}, \S 3^{\circ}\right)$.

\footnotetext{
181 “Art. 323. Quando não for caso de inadmissibilidade do recurso por outra razão, o(a) Relator(a) ou o Presidente submeterá, por meio eletrônico, aos demais Ministros, cópia de sua manifestação sobre a existência, ou não, de Repercussão Geral.

(...)

$\S 3^{\circ}$ Mediante decisão irrecorrível, poderá o(a) Relator(a) admitir de ofício ou a requerimento, em prazo que fixar, a manifestação de terceiros, subscrita por procurador habilitado, sobre a questão da Repercussão Geral."

${ }^{182}$ Cf. op.cit., p. 63.
} 
Em que pese a existência de críticas $^{183}$, a irrecorribilidade da decisão que admite a intervenção de terceiro no exame da Repercussão Geral é medida razoável e adequada à realidade fática do Poder Judiciário brasileiro, condizente com o próprio sistema que instituiu esse filtro recursal.

A possibilidade de interposição de recurso contra a decisão que admite a participação do amicus curiae acabaria por gerar mais um incidente processual, a ser processado e julgado pelo STF, na contramão da solução que se buscou obter com a instituição de um mecanismo seletor de demandas capaz de reduzir a sobrecarga de processos submetidos à apreciação do Supremo Tribunal Federal.

De outro lado, não parece fazer sentido que a decisão que admite a participação de amicus curiae possa ser alvo do inconformismo de eventuais interessados, ao passo que a própria decisão a respeito da presença, ou não, da Repercussão Geral da questão constitucional é irrecorrível ${ }^{184}$.

Por fim, importante notar que a atuação do amicus curiae, além dos poderes de apresentar informações que auxiliem no deslinde da causa, apresentar memoriais, opor embargos de declaração e sustentar oralmente duas razões, deve ser pautada pelos já conhecidos deveres processuais de lealdade e boa-fé, nos termos do art. 14 do Código de Processo Civil.

Fica claro, portanto, que a intervenção do amicus curiae é uma ferramenta adicional de defesa, que proporciona representatividade à sociedade em assuntos de eminente relevância.

Até o próprio Supremo Tribunal Federal já reconheceu que a atuação do amicus curiae configura um "fator de legitimação social das decisões da Suprema Corte" e faz com que "se realize, sempre sob uma perspectiva eminentemente pluralística, a possibilidade de participação formal de entidades e de instituições que efetivamente representem os interesses

\footnotetext{
${ }^{183}$ Como exemplo, podemos citar, mais uma vez, Eduardo Talamini, para quem o problema de eventual atraso no trâmite do recurso e sobrecarga do Tribunal poderia ser resolvido de outras formas, através da simplificação do procedimento e alargamento das hipóteses de julgamento eletrônico. Para o autor, a intervenção do amicus curiae é tão relevante que vedar a possibilidade de recurso contra a decisão que a denegar acaba por macular a própria constitucionalidade dessa norma: "A fundamental importância do amicus curiae para a legitimação dos mecanismos adotados na jurisdição constitucional aconselha postura diversa da atual: a autorização da intervenção do terceiro não é um favor que se concede a alguém, uma liberalidade do Tribunal, mas importante instrumento de consecução do devido processo e de maior qualificação do próprio resultado final do processo. Se a definição da presença do terceiro pode afetar o curso processual - à parte esse ser em alguma medida o preço pago pela legitimidade constitucional do processo -, cabe formular mecanismos procedimentais que simplifiquem a questão, tal como se fez relativamente à própria aferição da Repercussão Geral (deliberação eletrônica)." (Cf. op.cit., p. 64).

${ }^{184}$ Ressalva feita, no entanto, quanto à oposição de embargos de declaração, nos termos do art. 535 do Código de Processo Civil, caso a decisão esteja maculada com os vícios de obscuridade, omissão ou contradição, como se verá a seguir.
} 
gerais da coletividade ou que expressem os valores essenciais e relevantes de grupos, classes ou estratos sociais" ${ }^{\prime 185}$.

Segundo CÁssio ScARPINELla BuEno,

"a única forma de legitimar as decisões do Supremo Tribunal Federal, sobretudo daquelas que projetam eficácia sobre um número considerável de jurisdicionados é reconhecer que ele deve, previamente, dar ouvidos a pessoas ou entidades representativas da sociedade civil - e, até mesmo, a pessoas de direito público que desempenhem, de alguma forma, esse mesmo papel, capturando os próprios valores dispersos do Estado, suas diversas opiniões e visões de políticas públicas a serem perseguidas também em juízo -, verificando em que medida estão configurados adequadamente os interesses, os direitos e os valores em jogo de lado a lado". ${ }^{186}$

E, como bem conclui EDUARDO TALAMINI: "a razoável admissão do amicus curiae é a pedra de toque da legitimidade participativa da nova jurisdição constitucional brasileira" 187 .

\section{$\underline{3.4 \text { Os aspectos polêmicos }}$}

3.4.1 A admissibilidade e o julgamento do mérito de recurso extraordinário que versa sobre diferentes questões constitucionais

Um dos pontos mais polêmicos a respeito do instituto da Repercussão Geral da questão constitucional é a existência, na mesma decisão, de diferentes capítulos, sendo apenas um (ou alguns) dotado(s) de relevância suficiente a ensejar a apreciação pelo Supremo Tribunal Federal.

A questão que se coloca é a seguinte: impugnadas duas ou mais questões constitucionais e entendendo o STF que apenas uma delas apresenta Repercussão Geral, podem as demais questões ser também julgadas com o mérito do recurso extraordinário? Ou a atuação do Supremo Tribunal Federal deve ficar restrita, nos estritos termos da lei, às questões dotadas de significativa relevância?

A despeito da existência de respeitáveis entendimentos em sentidos diversos ${ }^{188}$, a razão parece estar com quem defende que, vencida a barreira da admissibilidade, em razão do

\footnotetext{
${ }^{185}$ Cf. ADI no 2130 MC-SC, j. em 20.12.2000, rel. Min. Celso de Mello, p. 145.

${ }^{186}$ Cf. op.cit., pp. 626-627.

${ }^{187}$ Cf. op.cit., p. 63.
} 
reconhecimento da Repercussão Geral de, ao menos uma, das questões constitucionais discutidas, o mérito do recurso extraordinário deve ser integralmente julgado (desde que preenchidos os demais pressupostos recursais), ainda que isso implique na apreciação, pelo Supremo Tribunal Federal, de alguma(s) questão(ões) desprovida(s) de relevância.

Isso se deve, em primeiro lugar, à natureza do Supremo Tribunal Federal enquanto órgão judicante, a quem compete não apenas a fixação de teses e orientação de entendimentos jurisprudenciais, mas o próprio julgamento do mérito de (selecionadas) causas, "aplicando o direito à espécie"

É a partir dos julgamentos realizados pelo Supremo Tribunal Federal que são extraídas as teses a serem observadas nos demais graus de jurisdição, a exemplo do que ocorre com as súmulas vinculantes. Daí falar-se que o STF é um órgão judicante, e não meramente paradigmático.

Assim, vencida a barreira da admissibilidade, deverá o Supremo Tribunal Federal julgar integralmente o mérito do recurso extraordinário admitido.

Nesse sentido, ressalta André de AlbuQuerque CAVAlCANTi AbBud:

“A intenção de mão dupla do novo requisito constitucional é, em igual grau de relevo, tanto excluir do conhecimento do Supremo Tribunal Federal questões desprovidas daquela repercussão quanto determinar o julgamento das pretensões recursais de tal modo importantes. Não se pretendeu esvaziar o papel do Tribunal em relação aos recursos extraordinários, mas sim restringi-lo às matérias que, em razão de sua especial relevância, são realmente compatíveis com o papel constitucional de nossa Corte Suprema. Julgar-se-ão menos recursos, é certo, mas para que os demais sejam apreciados com a prudência e a ponderação que a magnitude da matéria neles versada impõe."190

É essa, inclusive, a posição externada pelo próprio Supremo Tribunal Federal, ao editar a Súmula $\mathrm{n}^{\circ}$ 456: “O Supremo Tribunal Federal, conhecendo do recurso

\footnotetext{
${ }^{188}$ Arruda Alvim sustenta que as questões não dotadas de Repercussão Geral devem ficar excluídas da apreciação do Supremo Tribunal Federal: "É, como se disse, um filtro pelo qual estão genericamente admitidos recursos extraordinários em relação aos quais sejam caracterizados por ter Repercussão Geral, e, nesse sentido, se está discriminando que somente a questão constitucional em relação à qual se reconheça Repercussão Geral é que comportará o recurso extraordinário. Todas as questões constitucionais que não sejam dotadas desse atributo, pela EC n. 45, estão excluídas da possibilidade de recurso extraordinário. este último conjunto de questões constitucionais passou a ser objeto de 'veto' constitucional, em que se estabeleceu o não-cabimento de recurso extraordinário." (Cf. op. cit., p. 65). Também nesse sentido, são as palavras de Eduardo Talamini: "Se o recurso extraordinário versar sobre uma pluralidade de questões constitucionais, será necessário aferir a Repercussão Geral relativamente a cada uma delas. A circunstância de uma, ou algumas, dessas questões atender à nova exigência não dispensa as demais de também a cumprirem." (Cf. op. cit., p. 34). ${ }^{189}$ Nos dizeres da Súmula 456 do STF.

${ }^{190}$ Cf. op. cit., p. 299.
} 
extraordinário, julgará a causa, aplicando o direito à espécie"191 e a Súmula no 528: "Se a decisão contiver partes autônomas, a admissão parcial, pelo presidente do tribunal 'a quo', de recurso extraordinário que, sobre qualquer delas se manifestar, não limitará a apreciação de todas pelo Supremo Tribunal Federal, independentemente de interposição de agravo de instrumento".

\subsubsection{A (ir)recorribilidade da decisão relativa à ausência da Repercussão Geral}

Outro ponto polêmico diz respeito à irrecorribilidade da decisão relativa à ausência de Repercussão Geral da questão constitucional em discussão, tal qual a regra insculpida já no caput do art. 543-A do Código de Processo Civil ${ }^{192}$.

Isso porque, a despeito do que expressamente previsto pela legislação aplicável à matéria e de posicionamentos doutrinários mais radicais ${ }^{193}$, algumas pontuais ressalvas devem ser feitas a essa regra.

A primeira - e mais óbvia delas - se refere ao cabimento de embargos de declaração, mesmo contra decisão proferida pelo Plenário do Supremo Tribunal Federal.

O cabimento dos embargos de declaração é sabidamente irrestrito, destinado a aclarar toda e qualquer decisão judicial, nos termos do art. 535 do Código de Processo Civil e de consolidados entendimentos da doutrina e jurisprudência, em homenagem ao postulado da necessidade de suficiente fundamentação das decisões judiciais, conforme o art. 93, IX, da Constituição Federal ${ }^{194}$.

\footnotetext{
${ }^{191}$ À luz do disposto pela Súmula no 456 acima transcrita, ressaltam Theotonio Negrão, José Roberto F. Gouvêa e Luis Guilherme A. Bondioli que "a existência no recurso de uma única questão dotada de Repercussão Geral já é suficiente para o rompimento da barreira da admissibilidade. Uma vez rompida essa barreira, mesmo questões desprovidas de Repercussão Geral podem ser apreciadas, na medida em que, conhecido o recurso, deve o STF julgar a causa (Súmula 456 do STF)." (Cf. op. cit., nota 4c ao art. 543-A, p. 771).

192 "Art. 543-A. O Supremo Tribunal Federal, em decisão irrecorrível, não conhecerá do recurso extraordinário, quando a questão constitucional nele versada não oferecer Repercussão Geral, nos termos deste artigo." (grifos nossos).

${ }^{193}$ Por exemplo, Ricardo de Barros Leonel, para quem a decisão que não conhece do recurso extraordinário por ausência de Repercussão Geral da questão constitucional é absolutamente irrecorrível, em função da opção "não só correta como possível" do legislador. Para o jurista, a irrecorribilidade se justifica por não haver qualquer inconstitucionalidade na regra, uma vez que o recurso extraordinário não deve ter por finalidade servir como veículo para o exercício do duplo grau de jurisdição, mas funciona como instrumento para que seja conferida uniformidade à interpretação e aplicação do direito constitucional. Ademais, entende Leonel que a decisão do Plenário do STF deve ser tida como a palavra final no caso, sem prejuízo de que, em casos futuros, a tese seja revista pelo colegiado, nos termos do 543-A, § $5^{\circ}$, do Código de Processo Civil.

${ }^{194}$ Nas palavras de Barbosa Moreira: "ainda quando o texto legal, expressis verbis, a qualifique de 'irrecorrivel', há de entender-se que o faz com a resalva implícita concernente aos embargos de declaração." (Cf. op. cit., p. 548). No mesmo sentido, Rodolfo de Camargo Mancuso: "De todo modo, cremos que não se pode excluir a interposição de embargos de declaração quando a decisão sobre Repercussão Geral se ressinta de contradição, obscuridade ou omissão em seus termos (CPC, art. 535 e incisos), descabendo reduzir o
} 
Os embargos de declaração têm a função de aclarar o julgado, de modo a deixá-lo completo e indene de dúvidas - característica esta essencial, especialmente em relação à Repercussão Geral de uma questão constitucional e aos desdobramentos de seu reconhecimento (ou afastamento) ${ }^{195}$.

Conforme destacam Luiz GuILHERME MARINONI E DANIEL MitidiERO:

"Se a necessidade de apresentar-se uma tutela jurisdicional clara, coerente e completa já se mostra fundamental no cotidiano dos casos, a importância dos embargos de declaração em tema de análise da Repercussão Geral de determinada controvérsia é ainda mais clara, na medida em que as razões pelas quais o Supremo Tribunal Federal decidiu não conhecer de eventuais recursos extraordinários servem, potencialmente, para a solução de outras controvérsias semelhantes (art. 543-A, § 5 , do CPC). Ainda que os embargos de declaração não visem a modificar o julgado, é imprescindível que se viabilize a todos os jurisdicionados uma perfeita compreensão do posicionamento do Supremo Tribunal Federal a respeito da relevância e transcendência dessa ou daquela controvérsia levada a seu conhecimento.",196

Nesse sentido, também as palavras de EDUARDO TALAMINI:

"Em primeiro lugar, mesmo em face de decisões do Plenário, cabem, sempre, embargos de declaração, destinados a eliminar eventuais contradições, obscuridades ou omissões contidas no acórdão. Afinal, os embargos declaratórios incidem irrestritamente em face de toda e qualquer decisão judicial, inclusive como meio de assegurar a observância do art. 93, IX, da Constituição Federal.",197

Outra ressalva - um tanto quanto mais problemática - fica por conta da possibilidade de cabimento de mandado de segurança contra a decisão relativa à ausência de Repercussão Geral.

De um lado, vê-se satisfeito o preceito estabelecido pelo art. $5^{\circ}$, II, da Lei $n^{\circ}$ 12.016/2009 e pela Súmula 267 do STF, qual seja, a expressa previsão legal da impossibilidade de revisão dessa decisão através de recursos - o que autoriza, a priori, a impetração do mandamus ${ }^{198}$.

pronunciamento do STF sobre tão relevante tema aos acanhados limites de um singelo despacho (irrecorrível, por ser mero ato de impulso processual, destituído de carga decisória-CPC, art. 504)." (Cf. op. cit., p. 181).

${ }^{195}$ Nesse mesmo sentido, Carolina Brambila Bega, op. cit., p. 121.

${ }^{196}$ Destaca Guilherme Beux Nassif Azem: "Têm, as partes, direito a um pronunciamento jurisdicional completo, imune de defeitos formais. Os efeitos decorrentes da aferição da Repercussão Geral, ademais, reforçam a necessidade de que a resolução emanada do STF revista-se da indispensável higidez." (Cf. op. cit., pp. 56-57).

${ }^{197}$ Cf. op. cit., pp. 64-65.

${ }^{198}$ Essa é a posição adotada por Carolina Brambila Bega, op. cit., p. 121. 
Há que se notar que o cabimento do mandamus se legitima, ainda, pela possibilidade, legalmente prevista, de revisão de entendimento acerca da Repercussão Geral, nos termos do art. 543-A, $\S 5^{\circ}$, do Código de Processo Civil, o que poderia ser feito através de mandado de segurança.

Luiz GuILHERMe MARINONi e DANIEL Mitidiero também fundamentam o cabimento do mandado de segurança no permissivo constitucional (art. 102, I, d) e na impossibilidade de sua restrição: "Embora existam precedentes do Supremo Tribunal Federal que não admitem mandado de segurança contra ato de seus Ministros, certo é que a Constituição autoriza a cogitação de seu cabimento (art. 102, I, d), grifando a jurisprudência dessa mesma Corte o regime de direito estrito dessa previsão, que não admite nem a sua ampliação, nem, tampouco, a sua restrição." 199

De outro lado, contudo, há alguns argumentos contra essa posição: há quem diga que não seria cabível a impetração de mandado de segurança contra a decisão acerca da ausência da Repercussão Geral pelo fato de que o mandamus seria julgado pelo mesmo colegiado que, recentemente, apreciou a existência de Repercussão Geral da questão sub judice e praticou o ato impugnado. Isso, contudo, como bem ressaltado por EDUARDO TALAMINI $^{200}$, não pode ser o elemento justificador do não-cabimento deste remédio; trata-se, em verdade, de razão para a sua concessão ou não, ou seja, é aspecto atinente ao mérito da própria controvérsia.

Ainda nessa linha, GuILHERME BeuX NASSIF AZEM defende o não cabimento do Mandado de Segurança na hipótese, sustentando que a orientação contida no art. 102, I, $d$, da Magna Carta é válida apenas para as atividades administrativas do Supremo Tribunal Federal, e não às suas decisões judiciais ${ }^{201}$.

Pode-se pensar, ainda, que ao se entender pelo cabimento de mandados de segurança contra a decisão que afasta a existência de Repercussão Geral, surgiriam, então, para as partes litigantes, novas portas de entrada para o Supremo Tribunal Federal, novas formas de externar seu inconformismo e irresignação, que acabariam, invariavelmente, por sobrecarregar, novamente, o STF, desvirtuando, assim, o verdadeiro intuito da criação do filtro da Repercussão Geral.

\footnotetext{
${ }^{199}$ Cf. op. cit., p. 68.

200 "Na hipótese ora em exame, pode-se também cogitar de uma falta de interesse processual, fundada na circunstância de que o mandado de segurança seria apreciado exatamente pelo mesmo colegiado que praticou (e recentemente) o ato impugnado. Mas (...) a falta de perspectiva de sucesso na medida não afasta a configuração do interesse processual. Concerne ao mérito da pretensão." (cf. op. cit., p. 57).

${ }^{201}$ Cf. op. cit., pp. 128-129.
} 
Contudo, a despeito do que defendem as vozes em sentido contrário, há que se reconhecer a possibilidade de impetração de Mandado de Segurança contra a decisão que nega a presença de Repercussão Geral da questão constitucional discutida no âmbito de um Recurso Extraordinário.

Isso porque, além dos motivos acima descritos, o mencionado efeito pernicioso de aumento dos processos submetidos ao julgamento do Supremo Tribunal Federal - argumento este válido para considerar inadmissíveis tanto mandados de segurança, quanto, igualmente, embargos de declaração - pode ser coibido se o STF agir com o endurecimento quanto à forma de interpretação, sendo combativo, caso a caso, quanto ao cabimento desses remédios.

Nesse sentido, pontua EDUADO TALAMINI que "eventuais abusos, inequivocamente caracterizados como tais, sujeitar-se-ão às medidas gerais que coíbem a má-fé processual"202; na mesma linha, GUILHERME BEUX NASSIF AZEM, especificamente sobre os Embargos de Declaração usados como meio procrastinatório do feito:

“(...) deve ser combativo quanto ao mau uso dos embargos, que poderá comprometer, caso se alastre a hipóteses não previstas em lei, a racionalidade almejada com a instituição do mecanismo de filtragem (...) Em tais hipóteses, a multa prevista no art. 538, parágrafo único, do CPC, desempenhará caráter pedagógico. Também o parágrafo único do art. 14 do diploma processual poderá ser utilizado para coibir atitudes atentatórias ao dever de lealdade processual., 203

Por fim, há, ainda, dois cenários em que se vislumbra a possibilidade de interposição de recurso de agravo contra a decisão afeta à Repercussão Geral, proferida monocraticamente pelo Presidente do Tribunal ou pelo Relator ${ }^{204}$.

O primeiro deles se refere à aplicação da decisão proferida pelo Plenário do Supremo Tribunal Federal a outros recursos de idêntica controvérsia. Nesses casos, a decisão singular é atacável mediante a interposição de recurso de agravo, nos termos do art. 557, § $1^{\circ}$, do Código de Processo Civil e art. 327, § 2º , do Regimento Interno do Supremo Tribunal

\footnotetext{
${ }^{202}$ Cf. op. cit., p. 58.

${ }^{203}$ Cf. op. cit., p. 127.

${ }^{204}$ Defendendo a recorribilidade apenas das decisões monocraticamente proferidas, são as palavras de Carolina Brambila Bega: "Frise-se que o Agravo, portanto, somente é cabível contra decisão monocrática, na qual se busca levar a discussão ao Plenário, principalmente nos casos em que a parte entender que o precedente não foi corretamente aplicado por se tratar de questão diversa da anteriormente julgada." (Cf. op. cit., p. 122) e Eduardo Talamini: "se a decisão provém do Plenário, não há como dela recorrer (nem a quem recorrer). Mas o pronunciamento do Plenário acerca da inexistência de Repercussão Geral relativamente a determinada matéria deve ser depois aplicado, mediante decisão monocrática, pelo Presidente do Supremo Tribunal Federall Tribunal ou pelo relator, a outros recursos idênticos quanto ao objeto. Nessa hipótese a decisão tomada individualmente é passível de recurso." (Cf. op. cit., p. 58).
} 
Federal, e se justifica pela necessidade de controle das decisões monocráticas - se estão elas a aplicar, corretamente, o quanto decidido pela Cúpula do Supremo Tribunal Federal.

Outro cenário em que a regra da irrecorribilidade resta plenamente afastada referese à decisão do Tribunal a quo que nega seguimento a recurso extraordinário por falta de Repercussão Geral; nestes casos, é cabível o recurso de agravo de instrumento, nos termos do art. 544 do Código de Processo Civil.

É apenas em relação a essas duas últimas hipóteses que HUMBERTO THEODORO JÚNIOR reconhece a possibilidade da interposição de recurso de agravo regimental, ou interno, nos termos dos artigos $317, \S 2^{\circ}$, e $327, \S 2^{\circ}$, do Regimento Interno do Supremo Tribunal Federal $^{205}$.

\subsubsection{A extensão do instituto da Repercussão Geral aos recursos especiais} $\underline{\text { submetidos ao julgamento do Superior Tribunal de Justiça }}$

Desde que instituída a Repercussão Geral como novo filtro de admissibilidade do recurso extraordinário, são inúmeras as vozes doutrinárias que questionam a pertinência da criação de outro instituto, à sua semelhança, aos recursos especiais, submetidos a julgamento pelo Superior Tribunal de Justiça ${ }^{206}$.

É cediço que a crise que assola o Supremo Tribunal Federal afeta igualmente o Superior Tribunal de Justiça, Corte de jurisdição também extraordinária que se vê, há algum tempo, sobrecarregada com uma infinidade de recursos pendentes de julgamento.

É o que defende ArRUdA AlviM:

"O que pode causar espécie é que - numa comparação - no plano do direito constitucional brasileira haja questões que não provoquem Repercussão Geral, ao passo que, no patamar relativo às questões legais de direito federal, todas elas provocam ou provocariam essa repercussão, dado que não resultou instituído - ou, ainda, não resultou instituído - esse sistema, ou análogo, para o STJ. Ao menos pela diversidade de tratamento pelo legislador constitucional, pode-se concluir desta forma. A crítica à instituição da Repercussão Geral, para

\footnotetext{
${ }^{205}$ Cf. op. cit., p. 117.

${ }^{206}$ A esse respeito, cabe destacar que, quando da proposta de criação da Emenda Constitucional $\mathrm{n}^{\circ} 45$, a Deputada Federal Zulaiê Cobra, em seu parecer, opinou pela adoção da Repercussão Geral também para os recursos especial e de revista, além dos extraordinários. Tal proposta, contudo, foi barrada pelo Plenário da Câmara dos Deputados. Sobre o tema, sintetiza Bruno Dantas: "Pelo parecer da Deputada Zulaiê Cobra, aprovado pela Comissão Especial, a Repercussão Geral seria exigida tanto em relação ao recurso extraordinário quanto ao especial e ao de revista. Na votação em plenário, porém, foram suprimidas as referências aos recursos especial e de revista, seguindo para o Senado Federal tão somente o texto relativo ao RE." (Cf. op. cit., p. 227).
} 
o STF, não procede; mas, o que, em nosso sentir, tem procedência é a nãoadoção de igual sistema para o STJ."207

Atentos a essa realidade, os Deputados Rose DE Freitas (PMDB/ES) e LuIZ Pitiman (PMDB/DF) são os autores da Proposta de Emenda Constitucional - PEC 209/2012, que prevê a inserção do parágrafo $1^{\circ}$ no art. 105 da Constituição Federal, com o seguinte teor:

"§ $1^{\circ}$. No recurso especial, o recorrente deverá demonstrar a relevância das questões de direito federal infraconstitucional discutidas no caso, nos termos da lei, a fim de que o Tribunal examine a admissão do recurso, somente podendo recusá-lo pela manifestação de dois terços dos membros do órgão competente para o julgamento."

Semelhante proposta de Emenda Constitucional adveio do Senado Federal, por iniciativa do Senador RICARdo FERRAÇO (PMDB/ES). A PEC 17/2013 também prevê a inserção do parágrafo $1^{\circ}$ no art. 105 da Constituição Federal, alterando, apenas, o órgão julgador competente para aferir a relevância da questão federal discutida ${ }^{208}$ :

“§ $1^{\circ}$. No recurso especial, o recorrente deverá demonstrar a relevância das questões de direito federal infraconstitucional discutidas no caso, nos termos da lei, a fim de que o Tribunal examine a admissão do recurso, somente podendo recusá-lo pela manifestação de dois terços dos membros da Corte Especial."

Ambas as propostas apresentam, em suas justificativas, a necessidade de redução do volume de recursos submetidos anualmente ao Superior Tribunal de Justiça, visando ganhos na celeridade processual e na eficiência dos julgamentos proferidos.

A ideia, aqui, é semelhante àquela que norteou a instituição da Repercussão Geral da questão constitucional: a criação de um novo requisito de admissibilidade dos recursos especiais, que permitirá que apenas as questões federais infraconstitucionais que revelem suficiente relevância sejam submetidas à apreciação do Superior Tribunal de Justiça.

\footnotetext{
${ }^{207}$ Cf. op. cit., p. 68.

${ }^{208}$ A atribuição da competência para o julgamento da relevância da questão federal infraconstitucional à Corte Especial do Superior Tribunal de Justiça, nos termos da proposta apresentada pelo Senado Federal, parece mais adequada. Ao contrário da PEC 209/2012, que atribui essa competência ao órgão responsável pelo julgamento do recurso (Turma, Seção Especializada ou Corte Especial), a apreciação da relevância da questão federal discutida exclusivamente pela Corte Especial elimina a possibilidade de entendimentos divergentes entre as diferentes Turmas do STJ, o que, como se sabe, daria ensejo à instauração de diversos incidentes de uniformização de jurisprudência, revelando-se, assim, ferramenta inócua à redução do volume de processos submetidos ao julgamento do Superior Tribunal de Justiça. Além disso, a exigência de manifestação de, pelo menos, dois terços dos membros da Corte Especial representa cerca de um terço dos membros do STJ, o que confere ainda mais legitimidade às decisões assim proferidas.
} 
Como visto, trata-se, também, de norma constitucional de eficácia limitada, a ser regulamentada por lei infraconstitucional ("nos termos da lei”), que veicula um conceito jurídico indeterminado ("relevância das questôes de direito federal infraconstitucional discutidas no caso"), com o intuito de filtrar os recursos submetidos ao julgamento do Superior Tribunal de Justiça.

Há, contudo, pertinentes críticas à criação desse novo requisito de admissibilidade dos recursos especiais.

Como bem salientam Marco Aurélio Serau Jr. e Denis Donoso, a chamada "taxa de reforma" é um importante índice a partir do qual deve ser analisada a viabilidade da instituição de um novo filtro de admissibilidade aos recursos especiais: "Quanto mais alta for esta taxa, menos conveniente é a lei que visa restringir o trânsito de recursos especiais" $" 209$.

Em outras palavras, a porcentagem de reforma das decisões proferidas pelos Tribunais Estaduais e pelos Tribunais Regionais Federais indicaria que a restrição ao acesso ao Superior Tribunal de Justiça não seria viável, justamente em razão da necessidade de controle e uniformização das decisões proferidas pelas Instâncias Ordinárias. Nesse sentido, há quem defenda que a solução para o problema da sobrecarga do Superior Tribunal de Justiça seria o fortalecimento do julgamento por amostragem e, em última análise, do papel de Corte de Cassação, com a ampliação do número de seus membros ${ }^{210}$.

Em contraposição a esse raciocínio, como já abordado anteriormente, não se pode esquecer que um dos reflexos da adoção de um mecanismo seletor de demandas é a valorização das decisões dos juízes de primeiro grau e dos Tribunais locais, que serão estimulados a aprimorar a qualidade de suas decisões, cientes de que serão elas, em muitos casos, definitivas e, como tais, precisarão resolver a lide e pacificar o conflito posto a julgamento da forma mais adequada e justa possível.

Por fugir do escopo do presente estudo, registra-se, aqui, apenas a necessidade de reflexão e debates acerca da viabilidade e pertinência (jurídica e fática) da criação de um novo filtro de admissibilidade, à semelhança da Repercussão Geral, aos recursos especiais.

\footnotetext{
${ }^{209}$ Cf. op. cit., p. 6.

${ }^{210}$ É esse o posicionamento defendido por Eduardo Talamini, para quem o aumento do número de membros do STJ é permitido pela própria Constituição Federal, justamente em razão da necessidade de adequação do perfil e das funções dessa Corte: "A solução é precisamente levar adiante essa característica do STJ que o torna pouco adequado para um modelo de filtragem pautado na relevância da matéria. Trata-se da ampliação significativa do número de membros, a fim de que ela assuma as feições equivalentes às das cortes de cassação europeias (algumas funcionando com centenas de membros). A própria Constituição anteviu esse caminho. Enquanto que para o Supremo Tribunal Federall Tribunal ela definiu exatamente o número de seus membros, para o STJ houve apenas a fixação de um número mínimo. Vale dizer: a própria Constituição não apenas autoriza o aumento do número de membros do STJ, como também, ao fazê-lo, deixa implícito que essa ampliação é consentânea com o perfil de atuação e as funções dessa Corte." (Cf. op. cit., pp. 235-236).
} 


\title{
4 AS INSPIRAÇÕES INTERNACIONAIS
}

A grande maioria dos países do mundo, já há algum tempo e ainda atualmente, se vê diante de um crescimento exacerbado do volume de litígios que, por não alcançarem uma solução consensual, são submetidos à intervenção estatal, através do julgamento do Poder Judiciário.

Nas palavras de BRUNO DANTAS:

\begin{abstract}
"Ocorre que desde o início do século passado se notam nos tribunais de cúpula dos diversos países as consequências da massificação das relações jurídicas, gerada, fundamentalmente, pela revolução industrial. Como é natural, o incremento no número de relações jurídicas acarreta diretamente o aumento do número de demandas levadas ao Poder Judiciário, o que, combinado com o movimento mundial pelo acesso à justiça, deflagrado na segunda metade do século XX, vem contribuindo sobremaneira para o assoreamento dos tribunais em todos os quadrantes do globo."211
\end{abstract}

Sobre o tema, em detida análise a respeito das Cortes Constitucionais da América Latina, expõe CÂNDIDO RANGEL DINAMARCO:

"Em todos os países existe um sistema de seleção de causas e questões com acesso à sua Corte Suprema. Em via recursal evita-se que questões de fato sejam repropostas perante o órgão de cúpula, geralmente conceituado como instância de superposição: sobrepõe-se a todos os demais órgãos judiciários e organismos judiciários (justiça comum, justiças especiais, justiça administrativa), mas aprecia exclusivamente questões jurídicas, com influência mais direta ou menos direta, mais intensa ou menos intensa, sobre os casos concretos em julgamento.",212

Assim, a necessidade da criação de um mecanismo seletor das demandas que alcançam as Instâncias Extraordinárias foi sentida em quase todos esses países, em especial naqueles de acentuada cultura litigante.

Deles vieram as principais influências estrangeiras para a criação da Repercussão Geral da questão constitucional, extraídas dos institutos criados pelos Estados Unidos da América, Alemanha, Argentina e outros países, como se verá adiante.

\section{$4.1 \mathrm{O}$ writ of certiorari norte-americano}

\footnotetext{
${ }^{211}$ Cf. Repercussão Geral: perspectivas históricas, dogmática e de direito comparado: questões processuais, pp. 96-97.

${ }^{212}$ Cf. A função das cortes supremas na América Latina, p. 5 - destaques no original.
} 
O writ of certiorari é o instituto norte-americano originariamente concebido para atuar como um filtro seletor das demandas que alcançam a Suprema Corte norte-americana e que tem inspirado a criação de mecanismos assemelhados em diversos países do mundo.

Trata-se de uma espécie de ordem, emitida pela Suprema Corte à Instância inferior, intimando-a a remeter um determinado caso concreto para sua revisão. Nas palavras de GuILherme BeuX NASSIF AzEM: "Consiste o writ of certiorari, especificamente, em uma ordem escrita a órgão inferior, para que este transmita o caso ao órgão superior para revisão" ${ }^{213}$.

Sua aplicação garante que somente as causas que apresentem "razões especiais" serão julgadas pela mais alta cúpula do Judiciário. Nesse sentido, constata ARAKEN DE ASSIS:

"O mecanismo permite ao tribunal selecionar os casos de grande significação para a nação e, ao mesmo tempo, limita o número de processos julgados pelo tribunal em cada ano judiciário. Logrou substancial sucesso e persuadiu os mais exigentes da excelência do mecanismo.",214

A indefinição de quais seriam essas "razões especiais" é a característica mais notável desse instituto. Críticas dão conta de que são adotados critérios discricionários, estabelecidos exclusivamente pela Suprema Corte norte-americana, em cada caso concreto, sem as exigências da publicidade e motivação; além disso, há quem diga que são baseados, geralmente, em preferências e orientações pessoais dos julgadores, envolvendo aspectos não apenas jurídicos, mas, muitas vezes, políticos ${ }^{215}$.

A discricionariedade atribuída à Suprema Corte norte-americana é tão extensa que a ela é facultado escolher quais questões tidas por importantes serão analisadas, ainda que mais de uma seja invocada no âmbito de um mesmo recurso. É a chamada limited grant of certiorari, que permite que, se a mesma petição de certiorari contiver duas questões constitucionais e a Suprema Corte se interesse apenas por uma delas, estaria ela autorizada a restringir sua análise e jurisdição exclusivamente àquela tida por relevante ${ }^{216}$.

\footnotetext{
${ }^{213}$ Cf. op. cit., pp. 42-43.

${ }^{214}$ Cf. Manual dos Recursos, p. 696.

${ }^{215}$ Nesse sentido, ressalta ARRUDA ALVIM que "na doutrina e jurisprudência norte-americanas diz-se que o erro da decisão inferior não é necessariamente decisivo para a arguição de relevância" (Cf. A EC n $n^{\circ} 45$ e o instituto da Repercussão Geral, p. 72, nota de rodapé no 11.

216 "No célebre caso Olmstead v. United States, em 1928, o presidente William Taft sustentou que a Corte tinha autoridade para limitar o exame a questões constitucionais e, em razão disso, poderia ignorar fundamentos infraconstitucionais da decisão recorrida (limited grant of certiorari). Desse raciocínio derivou a tese de que, se a mesma petição de certiorari contivesse duas questões constitucionais, e a Suprema Corte se interessasse por
} 
Outro reflexo da intensa discricionariedade da Suprema Corte norte-americana é a possibilidade de adiamento da apreciação de um writ of certiorari se a matéria por ele discutida for considerada ainda não adequadamente amadurecida nas Cortes inferiores ${ }^{217}$.

Criado pelo Judiciary Act, do Congresso norte-americano, em 13 de fevereiro de $1925^{218}$, o writ of certiorari restringiu a competência obrigatória da Suprema Corte e ampliou o seu poder discricionário, de forma a permitir que ela própria defina quais recursos serão apreciados.

Uma figura importante para a criação e aprovação do Judiciary Act de 1925 foi William Howard Taft $^{219}$, Presidente da Suprema Corte norte-americana até 1930 e para quem a discricionariedade da Corte deveria ser absoluta e ilimitada:

"Foi, porém, William Howard Taft quem, no ano de 1916, iniciou movimento pela limitação da jurisdição recursal (mandatory jurisdiction) da Suprema Corte, sustentando que esta deveria ser preservada apenas nas questões que envolvessem interpretação constitucional. Nos demais casos, Taft defendia que fossem concedidos amplos e discricionários poderes para que, em sede de writ of certiorari, a Corte decidisse o que deveria ou não ser examinado. A partir de 1921, quando foi nomeado Presidente da Suprema Corte, passou a trabalhar incessantemente pelo implemento de suas ideias de 'absoluta e ilimitada discricionariedade', o que alcançou parcialmente com a promulgação da lei de 1925., 220

Assim, a jurisdição da Suprema Corte norte-americana ficou restrita às hipóteses de (i) writ of certiorari e (ii) certification of questions, cuja aplicação prática foi sendo, aos poucos, esvaziada pela própria $\operatorname{Corte}^{221}$. Com isso, restou expressamente autorizado à

apenas uma delas, estaria autorizada a restringir sua jurisdição exclusivamente àquela." (Cf. Bruno Dantas, op.cit., pp. 103-104).

217 "Em outras palavras, a Suprema Corte dos EUA exerce juízo altamente subjetivo no sentido de avaliar o melhor momento de se pronunciar sobre uma determinada questão jurídica. Isso se deve, em grande medida, ao regime do stare decisis vigente naquele país, pois, diferentemente dos países de tradição romano-germânica, as decisões dos tribunais irradiam eficácia vinculante aos juízes e tribunais inferiores, e uma decisão precipitada da Suprema Corte poderia até mesmo inibir o florescimento de uma corrente jurisprudencial mais justa e consentânea com o sistema constitucional." (Cf. Bruno Dantas, op. cit., p. 114).

${ }^{218}$ A despeito de ser esse o entendimento da maior parte da doutrina, há quem sustente que o writ of certiorari existe nos Estados Unidos desde 1789. Nesse sentido, afirma Bruno Dantas: "Realmente, o certiorari existia no sistema de 1789, porém, como veremos, já em 1891 o Congresso atribuíra alguma liberdade para a Suprema Corte exercer sua jurisdição recursal em conformidade com o que reputasse relevante, embora tal prerrogativa, a essa altura, ainda fosse eminentemente secundária." (Cf. op.cit., pp. 100-101).

${ }^{219}$ Taft também foi Presidente dos Estados Unidos, nos anos de 1909 a 1913 e é o autor da obra The attacks on the courts and legal procedure.

${ }^{220}$ Cf. Bruno Dantas, op.cit., p. 102 - destaques no original.

${ }^{221}$ As - já poucas - hipóteses de mandatory jurisdiction, ou seja, de jurisdição obrigatória da Suprema Corte foram praticamente extintas em 1988, com a aprovação da Supreme Court Case Selection Act. Quanto aos casos de certification of questions, Bruno Dantas destaca o seu desuso, tendo sido admitido apenas quatro vezes entre os anos de 1946 e 2001 (Cf. op. cit., p. 104, nota de rodapé no 19). 
Suprema Corte norte-americana decidir quais demandas seriam submetidas a seu julgamento, em razão de sua especial importância.

O procedimento do writ of certiorari se inicia com o protocolo da petição de certiorari pela parte sucumbente perante a Suprema Corte, no prazo de 90 (noventa) dias contados a partir da intimação do acórdão proferido por Corte Federal de Recursos ou por Corte Estadual de última Instância. Após o protocolo, a parte adversa tem o prazo de 30 (trinta) dias para apresentar sua resposta, a qual poderá ser replicada pelo peticionário.

Cada um dos nove juízes (Justices) da Suprema Corte norte-americana conta com quatro assessores especiais para ajudá-los na tarefa de selecionar os casos que merecem apreciação, por sua relevância. Esses assessores são responsáveis pela elaboração de um memorando (comumente chamado de cert-pool memo) sobre a petição de certiorari analisada, no qual destacam os fatos relevantes e as questões de direito presentes no caso, indicando as razões pelas quais entendem pela concessão ou pela denegação do writ.

Após a análise de tais memorandos, os juízes elaboram uma lista dos processos que pretendem sejam discutidos e votados sobre a concessão do certiorari (a chamada discussion list), e, como consequência, nasce também a dead list, lista dos processos que, por não constarem da primeira listagem, são rejeitados sem maiores considerações.

Semanalmente, usualmente às sextas-feiras, os juízes da Suprema Corte norteamericana se reúnem em sessão especial e secreta, para analisar e votar os casos elencados na discussion list. São necessários os votos de, ao menos, quatro dos nove juízes (a chamada rule of four ou "regra dos quatro"), para que o caso analisado seja julgado pelo Plenário ${ }^{222}$.

Nas palavras de EDUARDO TALAMINI:

"Nos Estados Unidos, há um reduzidíssimo elenco de recursos de conhecimento obrigatório pela Suprema Corte (mandatory appeals). Quanto ao mais, o writ of certiorari é o instrumento usado pela parte para tentar convencer a Corte de que sua causa deve ser por ela examinada, por haver special and important reasons. É assente a ideia de que a Corte decide esse writ amparada em sua judicial discretion. A triagem dos writs of certiorari é delegada a um amplo quadro de assessores (law clerks), incumbidos de

\footnotetext{
${ }^{222}$ Vale notar que o ordenamento jurídico brasileiro também adotou, em certa medida, a rule of four no sistema de análise e julgamento da Repercussão Geral: o art. 543-A, § 4", do CPC prevê que "se a Turma decidir pela existência de Repercussão Geral por, no mínimo, 4 (quatro) votos, ficará dispensada a remessa ao Plenário." Trata-se, aqui, contudo, de quórum majoritário qualificado (quatro votos de cinco Ministros que compõem a Turma).
} 
elaborar um brief (single memo) para os ministros. São necessários os votos de quatro dos nove ministros para que o recurso seja admitido."223

Na prática, a seleção das causas a serem julgadas pela Suprema Corte norteamericana leva muito em consideração o interesse do Estado sobre os casos que têm repercussão nacional. Por isso, cerca de $75 \%$ (setenta e cinco por cento) dos pedidos de certiorari formulados pelo próprio Estado são atendidos, o que representa cerca de $95 \%$ (noventa e cinco por cento) dos casos efetivamente julgados pela Suprema Corte norteamericana $^{224}$.

Algumas importantes diretrizes do entendimento adotado pela Suprema Corte norte-americana foram editadas com as Rules of the Supreme Court of the United States, espécies de súmulas que denotam, em sua Parte III, algumas regras a respeito do procedimento da jurisdição da Suprema Corte sobre o writ of certiorari $^{225}$.

Como uma das mais relevantes orientações da Suprema Corte norte-americana, vale destacar a expressa no caput da Rule 10, segundo a qual a revisão em sede de certiorari não pode ser entendida como um direito subjetivo da parte prejudicada, e sim como manifestação da discricionariedade judicial. Além disso, esse provimento indica algumas das razões levadas em consideração pela Suprema Corte norte-americana para a concessão ou não do certiorari: (i) quando uma Corte Federal de Apelação adotou uma decisão em conflito com a decisão de outra Corte Federal de Apelação na mesma matéria, ou decidiu uma questão federal de forma conflitante com a decisão de uma Corte Estadual de última Instância, ou se distanciou tanto do procedimento judicial comum ou ratificou tal distanciamento perpetrado por uma corte inferior que se fez necessária a supervisão da Suprema Corte norte-americana; (ii) quando uma Corte Estadual de última Instância tenha decidido uma questão federal importante de forma conflitante com uma decisão de outra Corte Estadual de última Instância ou de uma Corte Federal de Recursos; e (iii) quando uma Corte Estadual ou uma Corte Federal de Recursos tenha decidido uma questão federal importante que não foi, mas deveria ter sido, examinada pela Suprema Corte norte-americana, ou decidiu uma questão federal

\footnotetext{
${ }^{223}$ Cf. Novos aspectos da jurisdição constitucional brasileira: Repercussão Geral, força vinculante, modulação dos efeitos do controle de constitucionalidade e alargamento do objeto do controle direto, p. 29 - destaques no original.

${ }^{224}$ Cf. Ives Gandra da Silva Martins Filho, idem.

${ }^{225}$ Disponíveis em http://www.supremecourt.gov/ctrules/2013RulesoftheCourt.pdf., dispõe sobre o conteúdo petition, momento de sua apresentação e outros aspectos procedimentais e materiais. Acesso em 17 de setembro de 2013.
} 
importante de forma conflitante com decisões relevantes da Suprema Corte norteamericana $^{226}$.

Leciona Araken de Assis que "o conhecimento do writ of certiorari, consoante a célebre Rule 19 (hoje Rule 17), 'is not a matter of right, but of sound judicial discretion, and will be granted only where there are special and important reasons therefor, ${ }^{, 227}$.

Ademais, também a relevância da questão de direito é sopesada para o acolhimento do writ of certiorari, tendo a Suprema Corte norte-americana já fixado alguns parâmetros de sua presença:

“i) decisões dos tribunais inferiores que acarretem sério obstáculo à aplicação efetiva da lei (equivalente à declaração de inconstitucionalidade), conforme se afirmou no caso United States $v$. Ruzicka;

ii) decisões dos tribunais inferiores que se insurjam contra uma boa e consolidada interpretação conferida à lei por órgãos públicos ou agências reguladoras (Albertson's Inc. v. Kirkingburg);

iii) questões novas ou problemáticas que estão postas em inúmeros casos pendentes nos tribunais inferiores, e que recomendem a intervenção da Suprema Corte, com a finalidade de dar soluções rápidas e definitivas, que sirvam de paradigma para os demais casos (Laining $v$. United States; United States $v$. Standard Oil Co.; United States v. Powell);

iv) questões que envolvam vultosas quantias de dinheiro (United States $v$. Mitchell; Commissioner $v$. Standard Life\&Accident Ins. Co.; United States $v$. Zazove; Alaska v. American Can Co.);

v) questões que tenham muitos interessados diretos, na qualidade de partes processuais (Patterson v. Lamb).,228

Assim, as orientações da Suprema Corte norte-americana a respeito do acolhimento do writ of certiorari podem ser, grosso modo, assim resumidas: (i) quando invocadas e demonstradas divergências jurisprudenciais (especialmente entre Cortes Federais

\footnotetext{
226 "Rule 10: Review on a writ of certiorari is not a matter of right, but of judicial discretion. A petition for a writ of certiorari will be granted only for compelling reasons. The following, although neither controlling nor fully measuring the Court's discretion, indicate the character of the reasons the Court considers: (a) a United States court of appeals has entered a decision in conflict with the decision of another United States court of appeals on the same important matter; has decided an important federal question in a way that conflicts with a decision by a state court of last resort; or has so far departed from the accepted and usual, course of judicial proceedings, or sanctioned such a departure by a lower court, as to call for an exercise of this Court's supervisory power; (b) a state court of last resort has decided an important federal question in a way that conflicts with the decision of another state court of last resort or of a United States court of appeals; (c) a state court or a United States court of appeals has decided an important question of federal law that has not been, but should be, settled by this Court, or has decided an important federal question in a way that conflicts with relevant decisions of this Court. A petition for a writ of certiorari is rarely granted when the asserted error consists of erroneous factual findings or the misapplication of a properly stated rule of law".

${ }^{227}$ Cf. op. cit., p. 710 ("não é uma questão de Direito, mas de aparente discricionariedade judicial, e será outorgado apenas quando houver especiais e importantes razões para tanto" - tradução livre).

${ }^{228}$ Cf. Bruno Dantas, op.cit., pp. 114-115.
} 
de Apelação, entre Cortes Estaduais e entre estas e as Cortes Federais); (ii) quando presentes alguns vícios processuais, que exigem a supervisão da Suprema Corte norte-americana; e (iii) quando houver repercussão geral, pela sua importância, de uma determinada questão ligada à legislação federal, julgada por uma Corte inferior. ${ }^{229}$

É fácil perceber, portanto, que o constituinte brasileiro se inspirou, em larga escala, no writ of certiorari para a criação do instituto da Repercussão Geral da questão constitucional.

Contudo, muito embora as semelhanças entre esses dois mecanismos de seleção de demandas sejam bastante evidentes, algumas diferenças são igualmente notáveis.

A esse respeito, destaca-se, de um lado, a mais absoluta discricionariedade da Suprema Corte norte-americana na análise das questões que justifiquem o acolhimento do writ of certiorari, em contraposição à vinculação do Supremo Tribunal Federal à letra da lei para, ainda que em certa medida, admitir a presença da Repercussão Geral quando o recurso extraordinário impugnar decisão contrária à jurisprudência dominante ou súmula por ele editada, nos termos do já mencionado parágrafo $3^{\circ}$ do art. 543-A do Código de Processo Civil.

Outra diferença entre esses dois institutos revela-se na ausência de qualquer parâmetro, pelas normas norte-americanas, do que seria entendido pela Suprema Corte por "questão importante" a justificar a concessão do pedido de certiorari, ao passo que a própria legislação brasileira fixou certos critérios - como a relevância econômica, política, social e jurídica - para a aferição da Repercussão Geral da questão constitucional tratada no bojo de recurso extraordinário.

Tais diferenças, contudo, justificam-se até mesmo em razão da nossa cultura jurídica romano-germânica - que certamente teria dificuldades em assimilar tamanha discricionariedade outorgada a um dos Poderes ${ }^{230}$-, e não são suficientemente profundas para

\footnotetext{
${ }^{229}$ Cf. Ives Gandra da Silva Martins Filho, idem. Nesse mesmo sentido, Bruno Dantas menciona estudo realizado em 1988, por Gregory Caldiera e John Wright, no qual foram apontados nove indícios de concessão do certiorari: "A lista, por ordem de importância, segundo os autores, é a seguinte: i) a União era autora; ii) havia mais de três intervenções de amici curiae apoiando o pedido de certiorari; iii) havia um conflito atual: a) entre dois ou mais tribunais federais, b) entre dois ou mais tribunais estaduais, c) entre um tribunal federal e um tribunal estadual ou d) entre a corte imediatamente inferior e um precedente da Suprema Corte; iv) havia duas ou três intervenções de amici curiae em apoio ao pedido de certiorari; v) havia uma ou mais intervenções de amici curiae em apoio ao certiorari; vi) o caso havia sido decidido em um sentido liberal pela corte imediatamente inferior; vii) havia uma ou mais intervenções de amici curiae contrariamente à concessão do certiorari; viii) a corte imediatamente inferior decidiu o caso de maneira não unanime ou reformou a decisão do tribunal a quo; ix) a petição alegava um conflito." (Cf. op. cit., p. 109).

${ }^{230}$ A esse respeito, aponta Ulisses Schwarz Viana: "Se esse modelo, nascido no common law, tivesse sido adotado no Brasil, por certo teria trazido uma perplexidade operacional mais grave do que a que foi gerada pela conformação dada à Repercussão Geral, devido a nossa tradição jurídica romano-germânica centrada na
} 
que reste afastada a evidente inspiração norte-americana para a criação da Repercussão Geral, com todas as particularidades fáticas ${ }^{231}$ e culturais que têm cada um desses países.

\subsection{A Rechtssache grundsätzlichen Bedeutung alemã}

Seguindo esse mesmo raciocínio, a Alemanha adotou a chamada Rechtssache Grundsätzlichen Bedeutung ou, para nós, a importância ou significação fundamental da questão de direito, como mecanismo seletor dos recursos de revisão passíveis de julgamento pela Corte Federal de Justiça (Bundesgerichtof - BGH), responsável por zelar pelo direito federal infraconstitucional.

Com a reforma processual alemã havida em 2001, a admissibilidade do recurso de revisão (Revision) ficou condicionada à concessão, pelas cortes regionais de recursos (Oberlandesgericht - OLG), de uma licença para recorrer (Zulassungsrevision), o que ocorreria em restritas hipóteses, quando (i) fosse discutida questão jurídica dotada de significação fundamental ou (ii) o julgamento da OLG estivesse em confronto com a jurisprudência da BGH, exigindo, assim, a uniformização da jurisprudência ${ }^{232}$.

A essência desse filtro é selecionar causas paradigmáticas, que versem sobre a correta interpretação de texto de lei, cuja solução vise a aperfeiçoar as instituições jurídicas e tenha o condão de repercutir seus efeitos para além da lide em que discutida.

Nesse sentido, é importante notar que, para a $\mathrm{BGH}$, o número de recursos de revisão que tenham por objeto uma determinada questão federal não pode ser considerado como um indicativo de sua significação fundamental.

Sobre o tema, leciona BRUNO DANTAS:

"Sobre o conteúdo da questão dotada de significação fundamental, Artur May sustenta que ela deve ser suficientemente paradigmática e que, julgada, reúna condições de repercutir além dos estritos limites da lide. Ademais, afirma que a questão deve ter em sua essência um ponto duvidoso de difícil solução, que não derive claramente de uma interpretação razoável do texto legal.

ideia do jus scriptum, o qual faz alguns tenderem à ideia de que tudo deve estar explicitado na norma escrita." (Cf. op.cit., p. 72).

${ }^{231}$ A instituição do writ of certiorari há décadas nos Estados Unidos revela uma gritante diferença existente entre os números de processos julgados pela Suprema Corte norte-americana e os feitos apreciados pelo Supremo Tribunal Federal: dados apontam que, apenas no ano de 1997, a Suprema Corte recebeu cerca de 8.000 (oito mil) processos, enquanto ao STF foram distribuídas cerca de 40.000 (quarenta mil) demandas.

${ }^{232}$ Assim resume Bruno Dantas: "Segundo esse dispositivo, a licença será concedida quando a questão jurídica discutida for dotada de significação fundamental (Grundsätzlichen Bedeutung) ou quando o aperfeiçoamento ou a uniformização da jurisprudência (die Fortbildung des Recht oder die Sicherung einer einheitlichen Rechtsprechung) requerer o pronunciamento da BGH.” (Cf. op.cit., p. 121). 
Vale dizer, os alemães resumem na fórmula Fortbildung des Rechts ('aperfeiçoamento do direito') o caráter que a questão que se pretende levar à BGH deve ter de, por si, e dado o seu caráter paradigmático, solucionar um ponto que enseje o aperfeiçoamento das instituições jurídicas: 'Logo, uma questão jurídica pode ser submetida se sua resposta for indispensável para o aperfeiçoamento do direito ou para a salvaguarda de uma interpretação jurídica uniforme'.,233

Ainda, nas palavras de ARAKEN DE ASSIS:

"O critério básico assenta na circunstância de que a revista não se destina a tutelar o interesse das partes de modo imediato, mas, diretamente, a unidade e a evolução do direito; por conseguinte, o litígio há de transcender o interesse privado." 234

A partir dessa breve explanação, é possível notar uma fundamental diferença entre a significação fundamental alemã e a Repercussão Geral nacional: de um lado, o filtro seletor alemão se destina a filtrar as questões federais, submetidas à apreciação da Corte Federal de Justiça alemã; por outro lado, a Repercussão Geral foi criada para selecionar as questões constitucionais dotadas de relevância suficiente a permitir o julgamento pelo Supremo Tribunal Federal.

Outra singularidade da significação fundamental alemã reside no fato de que a análise de sua presença é feita pela instância prolatora da decisão recorrida - no caso, as OLGs -, a quem incumbe conceder à parte sucumbente a exigida licença para recorrer. No Brasil, essa sistemática não foi repetida, ficando sob o exclusivo crivo do Supremo Tribunal Federal a aferição da presença, ou não, da Repercussão Geral enquanto requisito de admissibilidade dos recursos extraordinários.

De todo modo, assim como com o writ of certiorari norte-americano, tais diferenças não impedem o reconhecimento da influência do instituto alemão para a criação da Repercussão Geral.

${ }^{233}$ Cf. op.cit., pp. 117-118, citando Artur May, Die revision in den zivil-und verwaltungsgerichtlichen Verfahren.

${ }^{234}$ Cf. Araken de Assis, op. cit., p. 711. 


\section{$\underline{4.3 \text { A gravedad institucional argentina }}$}

Outro país, agora latino-americano, a sentir a necessidade de instituir um mecanismo de filtragem dos inúmeros recursos extraordinários submetidos à análise de sua Suprema Corte foi a Argentina.

Inspirada pelo writ of certiorari norte-americano ${ }^{235}$, a Lei $\mathrm{n}^{\mathrm{o}} 23.774 / 90$ alterou o art. 280 do Código Procesal Civil y Comercial de la Nación (CPCN) e facultou à Suprema Corte argentina a possibilidade de, discricionariamente, afastar de sua apreciação o recurso extraordinário que não apresentar lesão federal suficiente (falta de agravio) ${ }^{236}$ ou cujas questões discutidas careçam de substancialidade ou transcendência ${ }^{237}$.

Criou-se, assim, a chamada gravedad institucional, um critério de transcendência na seleção dos recursos a serem analisados pela Suprema Corte Argentina.

É, portanto, um critério discricionário, que permite que a Suprema Corte Argentina rejeite um recurso submetido ao seu julgamento sem qualquer motivação ou fundamento, bastando que não vislumbre - ainda que atendidos todos os demais requisitos legais - a existência de questão de "transcendental importância" que justifique sua análise.

Nas palavras de HuMBERTO THEODORO JÚNIOR:

"Tal como prevê, entre nós, a Emenda n 45, também no direito argentino, o recurso extraordinário para alcançar o exame de mérito da Suprema Corte tem de revelar uma Repercussão Geral (ou institucional) a ser extraída do seu objeto revelado pelas razões recursais."238

Assim, a chamada gravedad institucional assumiu duas vertentes, (i) a negativa, segundo a qual é legítimo à Suprema Corte argentina rechaçar a apreciação de determinado

\footnotetext{
${ }^{235}$ Isso porque, como bem apontado por Ulisses Schwarz Viana, o "modelo do controle de constitucionalidade argentino deriva do modelo difuso estadunidense". (Cf. op.cit., p. 85).

${ }^{236}$ Nesse sentido, leciona Augusto Morello que o conceito de lesão federal suficiente consiste na presença de dois requisitos (i) a negativa de vigência ao direito federal e (ii) de natureza grave, capaz de colocar em risco a integridade do ordenamento jurídico argentino. (Cf. La nueva etapa del recurso extraordinario: el "certiorari", pp. 137-138).

237 "Art. 280. Cuando la Corte Suprema conociere por recurso extraordinario, la recepción de la causa implicará el llamamiento de autos. La Corte, según su sana discreción y con la sola invocación de esta norma podrá rechazar el recurso extraordinario, por falta de agravio federal suficiente o cuando las cuestiones planteadas resultaren insustanciales o carentes de trascendencia." ("Art. 280. Quando a Corte Suprema conhecer de recurso extraordinário, o recebimento da causa implicará no chamamento dos autos. A Corte, segundo sua própria discricionariedade e através da aplicação desta única norma, poderá rechaçar o recurso extraordinário, por falta de suficiente violação à lei federal ou quando as questões invocadas não sejam substanciais ou carentes de transcendência." - tradução livre).

${ }^{238}$ Cf. Repercussão Geral no Recurso Extraordinário (Lei $n^{o} 11.148$ ) e Súmula Vinculante do Supremo Tribunal Federal (Lei $n^{o}$ 11.417), p. 103.
} 
recurso carente de transcendência, e (ii) a positiva, que permite à Suprema Corte argentina, através da interpretação a contrario sensu da mesma norma jurídica, flexibilizar os critérios para que possa apreciar a questão escolhida, ainda que não cumpridos todos os requisitos formais do recurso extraordinário.

Alguns aspectos desse instituto merecem destaque, entre eles o fato de que a decisão da Suprema Corte argentina a respeito da rejeição ou admissão do recurso extraordinário prescinde de fundamentação. O próprio dispositivo legal em comento estabelece que a decisão de rejeição do recurso extraordinário se dá mediante a sua simples invocação, sem que haja a necessidade de motivação.

Ademais, vale notar que, ao contrário do que se verifica no Brasil, a decisão que impede o conhecimento do recurso extraordinário pela Suprema Corte argentina é recorrível, através de reclamação (queja), nos termos do art. 285 do $\mathrm{CPCN}^{239}$.

Outro ponto de destaque é a menção da lei ao que se chama de “discricionariedade sã" da Suprema Corte argentina.

As construções teóricas e doutrinárias erigidas na tentativa de esclarecer o teor dessa expressão apontam no sentido de que se trataria de um "arbítrio legítimo, sensato, aproximadamente igualitário, e desde logo não arbitrário, nem equitativo, nem discriminatório e irrazoável",240; ou, ainda, um de um "critério privativo dos membros do Tribunal, que, por motivos de experiência pessoal, maturidade e alta responsabilidade, refletirá um juízo objetivo e prudente ${ }^{241}$.

Ademais, é importante notar que os critérios fixados pela lei argentina para a rejeição discricionária do recurso extraordinário pela Corte Suprema - a saber, a falta de suficiente violação à lei federal ou quando as questões invocadas não sejam substanciais ou carentes de transcendência - são, também, requisitos de cabimento do recurso em questão.

Isso equivale a dizer que, ausente grave violação à lei federal ou transcendência, a Suprema Corte argentina se vê diante de dois cenários: (i) poderá rejeitar discricionariamente o recurso extraordinário, por ausência da necessária gravedad institucional, mediante a

\footnotetext{
239 “Articulo 285. Cuando se dedujere queja por denegación de recursos ante la Corte Suprema, la presentación, debidamente fundamentada, deberá efectuar-se en el plazo que establece el segundo párrafo del art. 282. La Corte podrá desestimar la queja sin más trámite, exigir la presentación de copias o, si fuere necesaria, la remisión del expediente. Si la queja fuere por denegación del recurso extraordinario, la Corte podrá rechazar este recurso (...). Si la queja fuere declarada procedente y se revocare la sentencia (...)."

${ }^{240}$ É esse o entendimento de Néstor Sagües: "La descrecionalidad sana parece referirse a um arbitrio legitimo, sensato, aproximadamente igualitario, y desde luego no arbitrario, ni equitativo, ni discriminatorio $e$ irrazonable." (Cf. Derecho procesal constitucional: recurso extraodinario, p. 440 - tradução livre no texto).

${ }^{241}$ Segundo a percepção de Augusto Morello, citado por Bruno Dantas (Cf. op.cit., p. 125).
} 
aplicação do mencionado art. 280 do $\mathrm{CPCN}$; ou (ii) deverá não conhecer do apelo, por ausência de hipótese autorizadora de seu cabimento.

Em outras palavras, é possível perceber que a discricionariedade atribuída à alta Cúpula do Poder Judiciário argentino não é ilimitada: deixou a lei de outorgar à Suprema Corte argentina a possibilidade de conhecer, processar e julgar recurso extraordinário que revele suficiente violação à lei federal ou que invoque questões substanciais, se ausente determinado(s) requisito(s) de admissibilidade ${ }^{242}$.

Ainda assim, e a despeito do sucesso estatístico do instituto ${ }^{243}$, a gravedad institucional foi alvo de críticas de boa parte da doutrina argentina. Uma dessas críticas, relativa à alegada inconstitucionalidade da norma criadora desse filtro recursal, é rebatida pelo fato de que já é garantido aos jurisdicionados o direito a uma sentença de Primeira Instância e à sua revisão por um Tribunal de Justiça, ambas devidamente fundamentadas, não se justificando, portanto, a obrigatoriedade de uma terceira instância de revisão ${ }^{244}$.

É possível perceber, portanto, que também o Direito argentino inspirou a criação da Repercussão Geral enquanto filtro seletor das demandas que aportam ao Supremo Tribunal Federal.

\subsection{Outros países: Reino Unido, Canadá, Austrália e Japão}

A instituição de um filtro recursal também foi adotada por outros países, como Reino Unido, Canadá, Austrália e Japão.

No Reino Unido, a Câmara dos Lordes - instituída como Corte de última Instância desde a Appellate Jurisdiction Act de 1876 - através de sua Comissão de Recursos, chamada Appeal Committee ${ }^{245}$, tem o poder de conceder a licença para recorrer (leave to appeal), de acordo com a relevância pública geral da questão discutida.

Nos termos da instrução 4.7 da House of Lords Practice Directions and Standing Orders Applicable to Civil Appeals ${ }^{246}$, a licença para recorrer é concedida a petições que, na opinião da Comissão de Recursos, levantem um argumento de importância pública geral, que

\footnotetext{
${ }^{242}$ Essa situação é bem resumida por Bruno Dantas, segundo o qual "Em suma: a lei não deu à Corte a faculdade de admitir recursos que não preenchem aqueles requisitos de admissibilidade" (Cf. op.cit., p. 126).

${ }^{243}$ Negado por alguns doutrinadores argentinos, como Augusto Mario Morello, para quem o instituto argentino não se ajustou à sua fonte norte-americana e não alcançou o sucesso esperado.

${ }^{244}$ Cf. Ives Gandra da Silva Martins Filho, idem.

245 Composta por doze lordes, intitulados Lords of Appeals in Ordinary, ou "Lordes dos Recursos" (tradução ${ }_{246}$ livre). 
mereça ser apreciado pela Câmara. Nessa seara, a decisão que rejeitar o recurso prescinde de extensa fundamentação, bastando que Comissão de Recursos indique, de forma breve, suas razões $^{247}$.

A discricionariedade na concessão da licença para recorrer também foi outorgada à Suprema Corte Canadense, em 1974, baseada na importância pública da questão discutida para selecionar os recursos a serem julgados.

Segundo as informações institucionais disponibilizadas pela própria Suprema Corte Canadense,

"a maior parte dos recursos somente são examinados pela Corte se, na opinião do colegiado, o caso envolver uma questão de importância pública ou se ele levanta uma questão importante de direito (ou uma combinação de direito e fato) que assegure a intervenção da Corte. A Corte concede licença para recorrer baseada em sua concepção da importância pública que a questão de direito sustente num caso determinado. A Corte então tem controle sobre sua pauta de julgamentos e é capaz de supervisionar o crescimento e o desenvolvimento da jurisprudência canadense. (...) A Corte aprecia uma média de 500 a 600 pedidos de licença para recorrer por ano. Geralmente, a Corte não fundamenta sua decisão sobre a concessão de licença para recorrer.",248

Sistema semelhante ao instituído pelo Reino Unido foi também adotado na Austrália, onde a licença especial para recorrer (special leave to appeal) limita a jurisdição da High Court, ou Corte Superior, dotada de ampla discricionariedade para concedê-la.

A maioria dos casos efetivamente admitidos para julgamento pela Corte Superior Australiana são, em regra, relativos à interpretação da Constituição e de princípios de direito de importância pública ${ }^{249}$. Nas palavras de BRUNO DANTAS: “a Corte examinará se a questão

\footnotetext{
${ }^{247}$ No original: "Leave to appeal is granted to petitions that, in the opinion of the Appeal Committee, raise an arguable point of law of general public importance which ought to be considered by the House at this time, bearing in mind that the matter will already have been the subject of judicial decision and may have already been reviewed on appeal. A petition which in the opinion of the Appeal Committee does not raise such a point of law is refused on that ground. The Appeal Committee gives brief reasons for refusing leave to appeal but does not otherwise explain its decisions".

${ }^{248}$ Tradução livre. No original: "Most appeals are heard by the Court only if leave is first given. Leave to appeal is granted by the Court if the case involves a question of public importance or if it raises an important issue of law (or an issue of both law and fact) that warrants consideration by the Court. The Court's decision whether to grant leave to appeal is based on its assessment of the public importance of the legal issues raised in the case in question. The Court thus has control over its docket and is able to supervise the growth and development of Canadian jurisprudence. The majority of applications for leave to appeal are decided by the Court on the basis of written submissions filed by the parties. The Court considers an average of between 500 and 600 applications for leave to appeal each year. The Court generally does not give reasons for its decisions on applications for leave to appeal". (Cf. Disponível em http://www.scc-csc.gc.ca/court-cour/role-eng.aspx. Acesso em $24 \mathrm{de}$ setembro de 2013).

${ }^{249}$ Conforme informações extraídas do site da Corte Superior Australiana: "The High Court of Australia is able to deal with cases which come to it on appeal or which begin in the High Court itself. Cases which involve
} 
jurídica em discussão detém importância pública, seja decorrente de sua aplicação geral, seja da necessidade de unificar o entendimento pretoriano, ou, ainda, se o interesse da administração da justiça, de modo geral ou no próprio caso particular, requerer o posicionamento da corte sobre a questão em discussão." 250

Por fim, o ordenamento jurídico processual japonês prevê que, além das questões constitucionais e de casos mais precisos - como, por exemplo, a existência de decisão anterior da Suprema Corte japonesa em sentido contrário à decisão recorrida -, apenas os recursos dotados de relevância podem ser apreciados por sua Suprema Corte.

Nesse sentido, leciona HUMBERTO THEODORO JÚNIOR:

“(...) O primeiro é extraído do novo Código de Processo Civil do Japão, segundo o qual o direito de recorrer à Suprema Corte fica subordinado a um controle baseado no juízo daquela corte que reconheça, previamente, a existência de contrariedade a alguma decisão sua ou o envolvimento de questão de direito relevante."251

\section{E EDUARDO TALAMINI:}

"No Japão, as questões constitucionais ou atinentes a graves erros de procedimento enumerados no Código de Processo Civil têm acesso assegurado à Suprema Corte. Nos demais casos, cabe comprovar ou a divergência com um precedente da Corte ou a relevância da questão de direito (CPC japonês, art. 318)."252

\footnotetext{
interpretation of the Constitution, or where the Court may be invited to depart from one of its previous decisions, or where the Court considers the principle of law involved to be one of major public importance, are normally determined by a full bench comprising all seven Justices if they are available to sit.

Other cases which come to the High Court for final determination involve appeals against the decisions of the Supreme Courts of the States and Territories, of the Federal Court of Australia and of the Family Court of Australia and these are dealt with by a full court of not less than two Justices. In addition there are certain matters which can be heard and determined by a single Justice. The subject matter of the cases heard by the Court traverses the whole range of Australian law. It includes, for instance, arbitration, contract, company law, copyright, courts-martial, criminal law and procedure, tax law, insurance, personal injury, property law, family law, trade practices, etc. Most of the Court's work relates to the hearing of appeals against decisions of other courts. There is no automatic right to have an appeal heard by the High Court and parties who wish to appeal must persuade the Court in a preliminary hearing that there are special reasons to cause the appeal to be heard. Decisions of the High Court on appeals are final. There are no further appeals once a matter has been decided by the High Court, and the decision is binding on all other courts throughout Australia". (Cf. disponível em http://www.hcourt.gov.au/about/operation. Acesso em 24 de setembro de 2013).

${ }^{250}$ Cf. op.cit., p. 138.

${ }^{251}$ Cf. op. cit., p. 102 - destaques no original.

${ }^{252}$ Cf. op. cit., pp. 29-30.
} 
Em comum, todos os exemplos acima expostos exigem que as causas submetidas a julgamento por suas instâncias extraordinárias versem sobre questões relevantes, transcendentes e excepcionais.

Nas palavras de ARRUdA ALviM:

"Há, portanto, uma identidade de explicações em relação ao ato de reconhecimento da situação excepcional de uma causa, nos direitos alemão, argentino, japonês e norte-americano, entendimento esse igualmente que foi válido para nós, quando da arguição de relevância e o é atualmente, em face da Repercussão Geral."253

A despeito das inegáveis influências e inspirações nos institutos acima descritos, é preciso reconhecer a personalidade própria da nossa Repercussão Geral, cujas particularidades foram geradas a partir do exame da realidade do Poder Judiciário brasileiro.

${ }^{253}$ Cf. op. cit., p. 70 , nota de rodapé $\mathrm{n}^{\circ} 10$. 


\section{ANÁLISES ESTATÍSTICAS}

As informações estatísticas mais recentes, divulgadas pelo Supremo Tribunal Federal $^{254}$, demonstram que foi reconhecida a existência de Repercussão Geral em $71 \%$ (setenta e um por cento) dos temas levados à apreciação da Corte $^{255}$ :

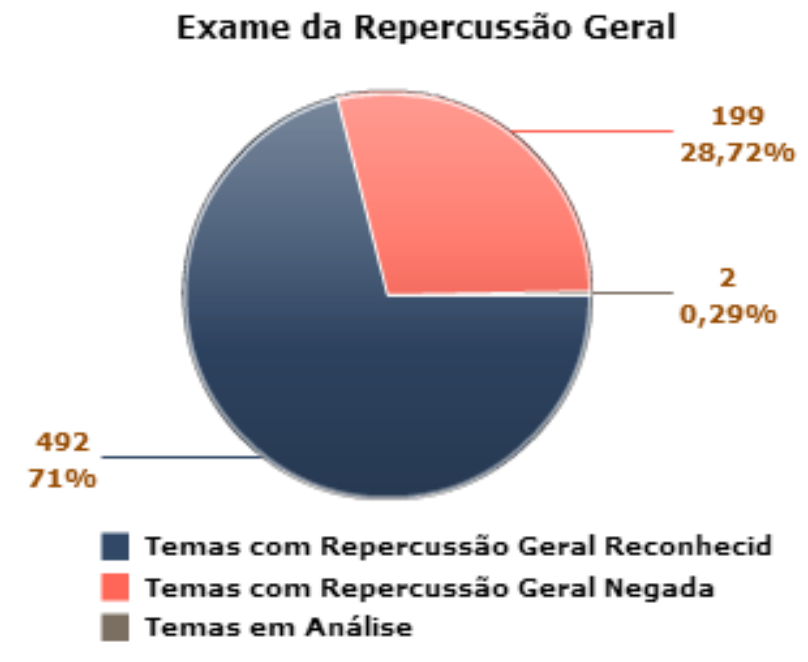

Nesse sentido, conforme dados atualizados até 03 de dezembro de 2013, foram distribuídos 4.787 (quatro mil, setecentos e oitenta e sete) processos com a preliminar de Repercussão Geral no segundo semestre de 2007. Já no mesmo período do ano de 2013, esse número subiu para 16.978 (dezesseis mil, novecentos e setenta e oito) processos, como demonstra a tabela abaixo ${ }^{256}$ :

\footnotetext{
${ }^{254}$ Disponíveis em http://www.stf.jus.br/portal/jurisprudenciaRepercussao/listarRepercussaoGeral.asp. Acesso $\underset{255}{\mathrm{em}} 31.12 .2013$.

Cf. disponível em (t).//s ussao. Acesso em 29 de dezembro de 2013 - dados atualizados até 03 de dezembro de 2013. $\frac{256}{256}$
disponível

Cf.

em

http://www.stf.jus.br/portal/cms/verTexto.asp?servico=jurisprudenciaRepercussaoGeral\&pagina=numeroReperc ussao. Acesso em 29 de dezembro de 2013.
} 


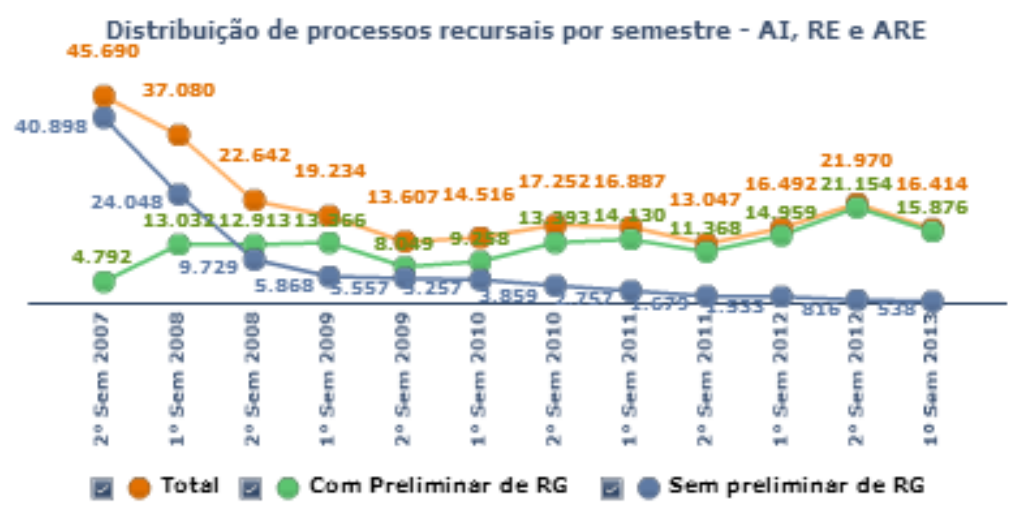

\begin{tabular}{|c|c|c|c|c|c|}
\hline \multirow{3}{*}{ Periodo } & \multicolumn{5}{|c|}{ Processos de Classes Recursais Distribuidos } \\
\hline & \multirow[t]{2}{*}{ Total } & \multicolumn{2}{|c|}{ Com Preliminar de RG } & \multicolumn{2}{|c|}{ Sem Preliminar de RG } \\
\hline & & Quantidade & $\%$ & Quantidade & $\%$ \\
\hline $2^{\circ}$ Sem 2007 & 45.690 & 4.792 & 10,49 & 40.898 & 89.51 \\
\hline $1=\operatorname{Sem} 2008$ & 37.080 & 13.032 & 35,15 & 24.048 & 64,85 \\
\hline $2^{\circ}$ Sem 2008 & 22.642 & 12.913 & 57,03 & 9.729 & 42,97 \\
\hline $1=\operatorname{Sem} 2009$ & 19.234 & 13.366 & 69,49 & 5.868 & 30,51 \\
\hline $2^{\circ} \operatorname{Sem} 2009$ & 13.607 & 8.049 & 59,15 & 5.557 & 40,84 \\
\hline $1=\operatorname{Sem} 2010$ & 14.516 & 9.258 & 63,78 & 5.257 & 36,22 \\
\hline $2^{2} \operatorname{Sem} 2010$ & 17.252 & 13.393 & 77,63 & 3.859 & 22,37 \\
\hline $1=$ Sem 2011 & 16.887 & 14.130 & 83,67 & 2.757 & 16,33 \\
\hline $2^{2}$ Sem 2011 & 13.047 & 11.368 & 87,13 & 1.679 & 12,87 \\
\hline $1=\operatorname{Sem} 2012$ & 16.492 & 14.959 & 90,70 & 1.533 & 9.30 \\
\hline $2^{2}$ Sem 2012 & 21.970 & 21.154 & 96.29 & 816 & 3,71 \\
\hline $1^{\circ}$ Sem 2013 & 16.414 & 15.876 & 96,72 & 538 & 3.28 \\
\hline $2^{\circ}$ Sem 2013 & 16.978 & 16.406 & 96.63 & 572 & 3,37 \\
\hline Total & 271.809 & 168.696 & 62.06 & 103.111 & 37,94 \\
\hline
\end{tabular}

De acordo com essas informações, desde o segundo semestre de 2007 até hoje, houve uma significativa redução de $64 \%$ (sessenta e quatro por cento) no número de recursos distribuídos aos Ministros da Corte.

Dados atualizados até 30.12.2013 revelam que a Repercussão Geral já foi reconhecida em 503 matérias, dentre as quais 173 já tiveram o seu mérito julgado ${ }^{257}$.

O impacto que esses dados produziram nas instâncias inferiores pode ser medido pelo número de processos impactados pelos julgamentos definitivos havidos em matéria de Repercussão Geral, graças ao reconhecimento de sua ausência ou, quando presente, em razão do julgamento de mérito proferido:

\footnotetext{
${ }^{257}$ Os dados relativos ao primeiro semestre de 2013 foram divulgados pelo Supremo Tribunal Federal no Boletim Repercussão Geral, disponível temas que tiveram Repercussão Geral reconhecida e mérito julgado no ano de 2013, destacamos, a título exemplificativo, a questão veiculada no $\operatorname{RE~} \mathrm{n}^{\circ} 589.998$, relatado pelo Ministro Ricardo Lewandowski, que decidiu, em 20.03.2013, que os servidores públicos de empresas públicas e sociedades de economia mista admitidos por concurso público não gozam da estabilidade preconizada pelo art. 41 da Constituição Federal, mas sua demissão deve ser sempre motivada. Acesso em 02 de janeiro de 2014.
} 


\begin{tabular}{|c|c|c|}
\hline Tribunal & $\begin{array}{l}\text { Ult. Data de } \\
\text { Atualização }\end{array}$ & $\begin{array}{c}\text { Qtd. } \\
\text { Processos }\end{array}$ \\
\hline Juizado Especial Federal do TRF da 2a Região & $21 / 10 / 2013$ & 6.986 \\
\hline Juizado Especial Federal do TRF da 3a Região & $13 / 09 / 2011$ & 8.767 \\
\hline Juizado Especial Federal do TRF da 4a Região & $13 / 09 / 2011$ & 23.964 \\
\hline Juizado Especial Federal do TRF da 5a Região & $13 / 09 / 2011$ & 13.060 \\
\hline Superior Tribunal de Justiça & $05 / 03 / 2012$ & 8.311 \\
\hline Tribunal de Justiça da Bahia & $26 / 03 / 2013$ & 205 \\
\hline Tribunal de Justiça de Minas Gerais & $05 / 06 / 2012$ & 2.473 \\
\hline Tribunal de Justiça de Pernambuco & $15 / 04 / 2013$ & 135 \\
\hline Tribunal de Justiça de Santa Catarina & $16 / 10 / 2013$ & 1.072 \\
\hline Tribunal de Justiça de São Paulo & $23 / 10 / 2013$ & 10.878 \\
\hline Tribunal de Justiça de Sergipe & $05 / 11 / 2013$ & 94 \\
\hline Tribunal de Justiça do Espírito Santo & $05 / 11 / 2013$ & 124 \\
\hline Tribunal de Justiça do Mato Grosso & $21 / 10 / 2013$ & 530 \\
\hline Tribunal de Justiça do Mato Grosso do Sul & $22 / 10 / 2013$ & 419 \\
\hline Tribunal de Justiça Do Paraná & $16 / 09 / 2013$ & 1.018 \\
\hline Tribunal de Justiça do Rio de Janeiro & $16 / 10 / 2013$ & 6.310 \\
\hline Tribunal de Justiça do Rio Grande do Norte & $20 / 09 / 2012$ & 44 \\
\hline Tribunal de Justiça do Rio Grande do Sul & $17 / 06 / 2013$ & 51.605 \\
\hline Tribunal Regional Federal da 1a Região & $24 / 09 / 2013$ & 3.600 \\
\hline Tribunal Regional Federal da 2a Região & $22 / 10 / 2013$ & 547 \\
\hline Tribunal Regional Federal da 3a Região & $20 / 12 / 2011$ & 3.500 \\
\hline Tribunal Regional Federal da 4a Região & $16 / 08 / 2012$ & 13.491 \\
\hline Tribunal Superior do Trabalho & $16 / 10 / 2013$ & 2.577 \\
\hline Total Geral & 05/11/2013 & 159.710 \\
\hline
\end{tabular}

A análise dos dados acima expostos revela que quase 160.000 (cento e sessenta mil) processos em trâmite na Instância Ordinária foram impactados pelas decisões proferidas pelo Supremo Tribunal Federal em matéria de Repercussão Geral. É possível, assim, afirmar, grosso modo, que é este o número aproximado de recursos impedidos de alcançar a Suprema Corte.

Segundo pesquisa realizada pelo Supremo Tribunal Federal junto às Instâncias de origem, as matérias mais recorrentes que aguardam decisão do Supremo Tribunal Federal acerca do reconhecimento da Repercussão Geral são: (i) os limites da negociação coletiva quanto à possibilidade de concessão de vantagem somente para os empregados da ativa, controvérsia originária do Tribunal Superior do Trabalho e que provocou o sobrestamento de 992 outros recursos; (ii) a extinção do contrato de trabalho pela aposentadoria espontânea, controvérsia também originária do Tribunal Superior do Trabalho e que provocou o sobrestamento de 502 outros recursos; e (iii) a progressão funcional de empregado que retorna 
ao serviço por ter sido reconhecida sua condição de anistiado, controvérsia novamente originária do Tribunal Superior do Trabalho e que provocou o sobrestamento de 277 (duzentos e setenta e sete) outros recursos. ${ }^{258}$

Ainda de acordo com esse mesmo levantamento, o tempo médio de espera para julgamento dos recursos repetitivos, sobrestados para aguardar o julgamento da Repercussão Geral do recurso paradigma, é de um a dois anos. ${ }^{259}$

A partir dos dados consolidados de quase sete anos de vigência do instituto da Repercussão Geral, foi possível selecionar alguns exemplos de leading cases julgados pelo Supremo Tribunal Federal que revelam a presença do requisito da transcendência em seus variados aspectos: econômico, político, social e jurídico.

A demonstração de Repercussão Geral por relevância econômica do tema é bem exemplificada pelo RE $\mathrm{n}^{\circ}$ 573.675, interposto pelo Ministério Público do Estado de Santa Catarina contra acórdão do Tribunal de Justiça local, que entendeu pela constitucionalidade da Lei Complementar 7/2002, criada pelo município de São José, para instituir a cobrança de contribuição para o custeio do serviço de iluminação pública - COSIP.

Após a breve explanação do mérito da questão de fundo tratada pelo presente recurso, os Ministros concluem que a solução do litígio interessa a um amplo espectro de pessoas, e ultrapassa o interesse subjetivo das partes litigantes.

Segundo o relator Ministro RICARDO LEWANDOWSKI, “Em pesquisa à jurisprudência da Corte, não identifiquei precedentes sobre o tema que permitam estabelecer limites ao poder de instituir dita contribuição, o qual, ressalte-se, é atribuído a todos os Municípios e ao Distrito Federal, de sorte que se mostra economicamente e juridicamente relevante, um entendimento dessa Corte que uniformize a prestação jurisdicional sobre a matéria”. E, nas palavras do Ministro MARCO Aurélio DE MELlo, “Em se tratando de processo objetivo, considerada norma da Carta do Estado elaborada à luz da Constituição

\footnotetext{
258 Esse rol é composto, ainda, pelas seguintes matérias: (i) Exigência de reserva de plenário para reconhecimento de vínculo empregatício entre o trabalhador e o tomador dos serviços sem a observância dos artigos 94 da Lei 9.472/1997 e 25 da Lei 8.987/1995; (ii) Dever do Estado de fornecer fraldas descartáveis a pessoa com doença grave que não possui condições financeiras para adquiri-las; (iii) Prazo prescricional relativo à indenização por danos morais e materiais decorrente de acidente de trabalho; (iv) Salário-hora contratual de empregado que trabalha em turnos ininterruptos de revezamento; (v) Expurgos em caderneta de poupança; (vi) Extensão, em relação aos servidores inativos, dos critérios de cálculo da Gratificação de sempenho de Atividade do Seguro Social - GDASS estabelecidos para os servidores em atividade. Dados disponíveis em http://www.stf.jus.br/arquivo/cms/jurisprudenciaRepercussaoGeralRelatorio/anexo/Resultados_apresentados.pdf. Acesso em 02 de janeiro de 2014.

259 Dados disponíveis $\quad$ em http://www.stf.jus.br/arquivo/cms/jurisprudenciaRepercussaoGeralRelatorio/anexo/Resultados_apresentados.pdf, p. 19. Acesso em 02 de janeiro de 2014.
} 
Federal, surge a Repercussão Geral. Tanto quanto possível, deve haver a manifestação do Supremo Tribunal Federal sobre o alcance da Lei Maior, evitando-se a repetição de decisões”.

A demonstração de Repercussão Geral por relevância política do tema é exemplificada pelo RE $\mathrm{n}^{\circ}$ 579.951, interposto pelo Ministério Público do Estado do Rio Grande do Norte contra acórdão proferido pelo Tribunal de Justiça local, que entendeu pela inaplicabilidade do disposto na Resolução 7/2005 do Conselho Nacional de Justiça aos Poderes Executivo e Legislativo, reputando constitucional e legal a nomeação de parentes de vereador e vice-prefeito do Município de Água Nova, para cargos em comissão da Administração.

Os Ministros entenderam que a nomeação de parentes para cargos e funções que não exigem concurso público ofende o princípio da impessoalidade, da isonomia e até mesmo o princípio da eficiência ${ }^{260}$, cuja observância configura verdadeiro pressuposto de validade dos atos praticados pelo administrador público.

Segundo o relator Ministro RICARDO LEWANDOWSKI, a questão em tela oferece Repercussão Geral, pois “diz respeito a princípio constitucional dirigido a toda Administração Pública, seja ela federal, estadual ou municipal, transcendendo, portanto, o interesse individual das partes”.E, nas palavras do Ministro MARCO AurÉLIO DE Mello, “o tema mostra-se relevante, em razão do envolvimento do interesse coletivo. Faz-se em jogo princípio basilar da Administração Pública que não precisaria sequer estar previsto expressamente na Constituição Federal - o da moralidade”.

O tema tratado se mostrou tão relevante que o julgamento em tela culminou com a edição da Súmula Vinculante no 13: "A nomeação de cônjuge, companheiro, ou parente, em linha reta, colateral ou por afinidade, até o $3^{\circ}$ grau, inclusive, da autoridade nomeante ou de servidor da mesma pessoa jurídica, investido em cargo de direção, chefia ou assessoramento, para o exercício de cargo em comissão ou de confiança, ou, ainda, de função gratificada na Administração Pública direta e indireta, em qualquer dos Poderes da União, dos Estados, do Distrito Federal e dos Municípios, compreendido o ajuste mediante designações recíprocas, viola a Constituição Federal”.

A demonstração de Repercussão Geral por relevância social do tema é exemplificada pelo RE $n^{\circ} 500.171$, interposto pela Universidade Federal de Goiás - UFGO contra acórdão proferido pela Quinta Turma do Tribunal Regional Federal da $1^{\text {a }}$ Região, que

\footnotetext{
${ }^{260}$ Cf. decisão proferida na ADI n ${ }^{\circ} 1.521 / \mathrm{RS}$, de relatoria do Ministro Marco Aurélio.
} 
entendeu que a cobrança de taxa de matrícula dos estudantes é incompatível com o disposto no artigo 206, IV, da Constituição Federal $^{261}$, ainda que os recursos assim obtidos sejam destinados a programas de assistência a alunos de "baixa condição sócio-econômicacultural”.

A Repercussão Geral da questão constitucional aqui debatida foi reconhecida em processo análogo, $\mathrm{RE} \mathrm{n}^{\circ}$ 567.801, de relatoria do eminente Ministro CARLOS ALBERTO MENEZES DIREITO. Foi reconhecida a presença da Repercussão Geral, pois a “discussão acerca da possibilidade da cobrança da denominada taxa de matrícula extrapola os interesses subjetivos presentes na causa, mostrando-se relevante para a maior parte das instituições públicas de ensino superior do país e de seus alunos”.

As palavras do Ministro MARCo AurÉlio DE MELlo expressam bem a importância do instituto da Repercussão Geral para o ordenamento jurídico e o sistema judiciário pátrios:

"O instituto da Repercussão Geral visa à racionalização dos trabalhos judicantes, levando o Supremo Tribunal Federal a pronunciar-se de forma vinculada - via Plenário, portanto - sobre o alcance de texto da Constituição Federal. Por isso, em situação concreta que se reproduza considerados múltiplos interesses jurídicos, há de abrir-se margem ao trânsito do extraordinário. Em síntese, tanto quanto possível, esta Corte deve delimitar o alcance da Carta da República, editando, a seguir, verbete de súmula com efeito vinculante".

Também neste caso, o tema tratado se mostrou tão relevante que o julgamento em tela culminou com a edição da Súmula Vinculante $n^{\circ}$ 12: "A cobrança de taxa de matrícula nas universidades públicas viola o disposto no artigo 206, inciso IV, da Constituição Federal".

\footnotetext{
261 “Art. 206. O ensino será ministrado com base nos seguintes princípios:

I - igualdade de condições para o acesso e permanência na escola;

II - liberdade de aprender, ensinar, pesquisar e divulgar o pensamento, a arte e o saber;

III - pluralismo de idéias e de concepções pedagógicas, e coexistência de instituições públicas e privadas de ensino;

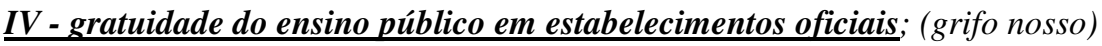

$V$ - valorização dos profissionais da educação escolar, garantidos, na forma da lei, planos de carreira, com ingresso exclusivamente por concurso público de provas e títulos, aos das redes públicas;

VI - gestão democrática do ensino público, na forma da lei;

VII - garantia de padrão de qualidade.

VIII - piso salarial profissional nacional para os profissionais da educação escolar pública, nos termos de lei federal.

Parágrafo único. A lei disporá sobre as categorias de trabalhadores considerados profissionais da educação básica e sobre a fixação de prazo para a elaboração ou adequação de seus planos de carreira, no âmbito da União, dos Estados, do Distrito Federal e dos Municípios".
} 
A demonstração de Repercussão Geral por relevância jurídica do tema é exemplificada pelo RE $\mathrm{n}^{\circ}$ 576.847, interposto por Telemar Norte Leste S/A em face de decisão da $5^{\text {a }}$ Turma Recursal dos Juizados Especiais Cíveis do Estado da Bahia, que indeferiu liminarmente o mandado de segurança impetrado contra decisão liminar, no âmbito de Juizado Especial ${ }^{262}$.

O Ministro relator Eros Grau, entendeu presente a Repercussão Geral da questão constitucional no caso acima exposto, pois sua resolução transcenderia o interesse subjetivo das partes envolvidas. Com as palavras do Ministro MARCo Aurélio DE Mello, fica, novamente, clara a finalidade do instituto, pois "o instrumental viabiliza a adoção de entendimento pelo Colegiado Maior, com o exercício, na plenitude, do direito de defesa. Em princípio, é possível vislumbrar-se grande número de processos, mas, uma vez apreciada a questão, a eficácia vinculante do pronunciamento propicia a racionalização do trabalho judiciário”.

De posse de todas essas informações e dados estatísticos, é possível observar que o instituto de Repercussão Geral tem logrado atingir seu objetivo primordial, ou seja, tem reduzido significativamente o volume de demandas submetidas à apreciação do Supremo Tribunal Federal, de tal modo que, hoje, o STF já pode debruçar-se apenas sobre as questões verdadeiramente importantes e que terão um impacto mais significativo à nação.

\footnotetext{
${ }^{262}$ A tutela jurisdicional que se buscava alcançar com o processo ajuizado perante o Juizado Especial Cível da Bahia era o reconhecimento da ilegalidade da cobrança da "tarifa básica de assinatura" e de "pulsos além da franquia" do serviço de telefonia fixa.
} 


\section{CONCLUSÕES}

A crise do Supremo Tribunal Federal, assolado há décadas por um sem-número de demandas submetidas a sua apreciação, se explica por algumas razões: (i) o contexto histórico-cultural em que a Constituição Federal de 1988 foi promulgada; (ii) a amplitude do espectro de questões passíveis de julgamento pela mais alta Corte do Poder Judiciário nacional, após a extinção dos obstáculos então existentes à interposição de recursos; (iii) a falta de aparelhamento técnico do Poder Judiciário e, ainda, (vi) a amplitude de nosso sistema recursal.

O Supremo Tribunal Federal tem a atribuição, expressamente descrita na Magna Carta, de salvaguarda da Constituição Federal e preservação da constitucionalidade (de forma difusa ou concentrada) e unidade do ordenamento jurídico nacional.

A ele, cumpre garantir a uniformidade e a observância ao direito objetivo da jurisprudência nacional, estabelecendo diretrizes e fixando posicionamentos que deverão ser seguidos por todas as demais Instâncias hierarquicamente inferiores, de modo a alcançar o ideal de unidade e inteireza do direito positivo brasileiro.

Contudo, a vultosa quantidade de recursos destinados à sua análise e julgamento acabou por afastar o Supremo Tribunal Federal de sua função primordial. Em última análise, pode-se dizer, ainda, que a crise institucional do Supremo Tribunal Federal se deve à massificação das relações jurídicas, que motivou o Direito Processual a buscar formas de, senão conter, racionalizar o avanço vertiginoso do número de conflitos postos ao crivo do Poder Judiciário $^{263}$.

Surgiu, então, a necessidade da criação de mecanismos de contenção dos recursos extraordinários, com o objetivo de racionalizar a atividade judicial brasileira e amenizar a crise do Poder Judiciário.

Nesse sentido, foram criados a arguição de relevância, primeira tentativa brasileira de se impor um filtro seletor às demandas que aportavam ao Supremo Tribunal Federal, à semelhança dos institutos adotados pelos sistemas norte-americano e alemão, e o

\footnotetext{
${ }^{263} \mathrm{O}$ mesmo fenômeno se deu com o Direito Material, culminando com a instituição de regimes regulatórios, como a edição do Código de Defesa do Consumidor. Adotando esse raciocínio, destacam Marco Aurélio Serau Jr. e Denis Donoso que "o legislador vem, paralelamente ao sistema processual coletivo, criando soluções processuais massificadas aplicáveis a processos individuais. Em outras palavras, nossa lei vem adotando paulatinamente métodos de 'coletivização' de julgamentos. Exemplos do que acabamos de citar são os seguintes (e recentes) institutos: súmula vinculante (art. 103-A da CF/1988 e Lei 11.417/2006), Repercussão Geral no recurso extraordinário ( art. 543-A do CPC), súmula impeditiva de recursos (art. 518, $\S 1^{o}$, do CPC), julgamento por amostragem do recurso especial (art. 543-C do CPC) e do recurso extraordinário (art. 543-B do CPC), julgamento prévio do mérito (art. 285-A do CPC) etc." (Cf. op. cit., p. 241).
} 
requisito da transcendência no âmbito da Justiça Especializada do Trabalho, como filtro ao processamento e julgamento de feitos pelo Tribunal Superior do Trabalho.

Embora bem estruturadas e dotadas de algum sucesso, essas modificações não conseguiram reduzir, de fato, a quantidade de recursos encaminhados ao Supremo Tribunal Federal, sobrecarregando, até mesmo, o Superior Tribunal de Justiça.

Foi diante da ineficiência desses mecanismos adotados para a solução da crise do Poder Judiciário que se tornaram ainda mais fortes os apelos para a criação e implementação de um verdadeiro filtro recursal, capaz de represar as demandas de pouca expressividade e afastá-las da jurisdição do Supremo Tribunal Federal.

Inspirada em experiências internacionais, extraídas de institutos adotados pelos Estados Unidos, Alemanha, Argentina e outros países, criou-se a Repercussão Geral da questão constitucional, instituto que visa a selecionar os processos em que sejam discutidas questões constitucionais relevantes, do ponto de vista econômico, político, social e jurídico, e cujos efeitos repercutam para além dos limites da demanda, de modo que apenas estes poderão ser submetidos ao julgamento do Supremo Tribunal Federal.

A partir de um conceito jurídico propositalmente indeterminado, que buscou fugir do risco de engessamento do sistema ao tentar delimitar e definir as inúmeras hipóteses concretas que poderiam surgir, ao longo do tempo, com a aplicação prática do instituto da Repercussão Geral, pretendeu o constituinte conceder ao aplicador do Direito uma maior margem de liberdade em sua interpretação casuística, de modo a permitir uma célere e constante adaptação da norma jurídica positivada às novas realidades fáticas e sociais que se apresentem.

Trata-se, assim, de mais um requisito de admissibilidade imposto ao conhecimento dos recursos extraordinários, dotado de certo viés político, que atua como um mecanismo de filtragem, permitindo que apenas alcancem o Supremo Tribunal Federal as teses dotadas de real importância e significado.

A diminuição do número de recursos submetidos ao julgamento do STF, almejada pela instituição da Repercussão Geral, provoca outras consequências igualmente benéficas para o aprimoramento do Poder Judiciário brasileiro, como o aumento da qualidade da prestação jurisdicional outorgada pelo Supremo Tribunal Federal, a valorização das decisões proferidas pelas Instâncias Ordinárias e o estímulo à concretização do ideal de duração razoável do processo.

Alguns pontos polêmicos a respeito do instituto da Repercussão Geral da questão constitucional foram destacados, como é o caso da existência, na mesma decisão, de 
diferentes capítulos, sendo apenas um deles dotado de relevância suficiente a ensejar a apreciação pelo Supremo Tribunal Federal.

A despeito da existência de respeitáveis entendimentos em sentidos diversos, viuse que, nesse caso, vencida a barreira da admissibilidade, em razão do reconhecimento da Repercussão Geral de, ao menos uma, das questões constitucionais discutidas, o mérito do recurso extraordinário deve ser integralmente julgado (desde que preenchidos os demais pressupostos recursais), ainda que isso implique na apreciação, pelo Supremo Tribunal Federal, de alguma(s) questão(ões) desprovida(s) de relevância. Isso se deve, principalmente, à natureza da Corte Constitucional enquanto órgão judicante, a quem compete não apenas a fixação de teses e orientação de entendimentos jurisprudenciais, mas o próprio julgamento do mérito de (selecionadas) causas.

Outro ponto polêmico diz respeito à irrecorribilidade da decisão relativa à ausência de Repercussão Geral da questão constitucional em discussão. A despeito do que expressamente previsto pela legislação aplicável à matéria e de posicionamentos doutrinários mais radicais, viu-se que o cabimento dos embargos de declaração é sabidamente irrestrito, destinado a aclarar toda e qualquer decisão judicial, em homenagem ao postulado da necessidade de suficiente fundamentação das decisões judiciais, conforme o art. 93, IX, da Constituição Federal. Além disso, viu-se a possibilidade de impetração de mandado de segurança contra a decisão que nega a presença de Repercussão Geral, bem como a possibilidade de interposição de recurso de agravo contra as decisões proferidas monocraticamente pelo Presidente do Tribunal ou pelo Relator.

Destacou-se, ainda, que o legislador brasileiro admitiu, expressamente, a possibilidade de intervenção de terceiros no processo de aferição da existência de Repercussão Geral, sob a forma de amicus curiae. Sua participação é permitida a entidades, órgãos e organizações não governamentais de defesa das liberdades civis, bem como a qualquer outro ente que demonstre ter interesse na solução da controvérsia, seja na demanda individualmente considerada, seja em razão dos efeitos que a decisão do Supremo Tribunal Federal é capaz de provocar.

Na prática, viu-se que o instituto da Repercussão Geral tem se revelado bastante eficiente: desde a sua criação até os dias de hoje, houve uma significativa redução de $64 \%$ (sessenta e quatro por cento) no número de recursos distribuídos aos Ministros da Corte.

A despeito de todas as conquistas, ainda é preciso cuidado ao antever os futuros desafios a serem enfrentados pelo novel instituto. 
O principal deles será o aprimoramento das técnicas de gestão do Poder Judiciário, em especial a adoção, gradativa, dos meios eletrônicos, seja para facilitar a comunicação entre as Instâncias, seja para administrar os acervos e facilitar o trâmite dos processos.

Além disso, não se pode perder de vista a necessidade, já observado por muitos doutrinadores, de uma transformação cultural, de modo a combater não só os reflexos, mais sensíveis, da crise que assola o Supremo Tribunal Federal, mas também a causa do problema.

Demonstrou-se, portanto, que o instituto de Repercussão Geral tem logrado atingir seu objetivo, ou seja, tem reduzido o volume de demandas submetidas à apreciação do Supremo Tribunal Federal, de tal modo que possa ele debruçar-se apenas sobre as questões verdadeiramente importantes e significativas à nação.

É preciso, contudo, manter os olhos voltados para o futuro, para que toda a experiência até hoje consolidada possa ser efetivamente empregada na superação de novos obstáculos e solução de novos entraves, com o fito de, sempre, manter o Supremo Tribunal Federal dedicado ao desempenho de sua mais primordial função: a de salvaguarda da Constituição Federal brasileira. 


\section{REFERÊNCIAS BIBLIOGRÁFICAS}

ABBUD, André de Albuquerque Cavalcanti. O anteprojeto de lei sobre a Repercussão Geral dos recursos extraordinários in Revista de Processo, São Paulo, nov. 2005, V. 129, pp. 108133.

ALMEIDA, Jean Alves Pereira. Repercussão Geral objetiva in Revista Dialética de Direito Processual, São Paulo, fev. 2011, V. 95, pp. 33-41.

ALVIM, Arruda. A arguição de relevância no recurso extraordinário. São Paulo: Editora Revista dos Tribunais, 1988.

A EC $n^{\circ} 45$ e o instituto da Repercussão Geral in Reforma do Judiciário.

Coord.: Teresa Arruda Alvim Wambier, Luiz Rodrigues Wambier, Luiz Manoel Gomes Júnior, Octavio Campos Fischer e William Santos Ferreira. São Paulo: Editora Revista dos Tribunais, 2005.

ALVIM NETTO, José Manuel de Arruda. STF rumo à flexibilização da jurisprudência defensiva. Disponível em http://www.oab.org.br/noticia/24648/artigo-stf-rumo-aflexibilizacao-da-jurisprudencia-defensiva. Acesso em 11 de janeiro de 2014.

ARAÚJO, José Henrique Mouta. A eficácia da decisão envolvendo a Repercussão Geral e os novos poderes dos relatores e dos tribunais locais in Revista de Processo, São Paulo, out. 2007, V. 152, pp. 181-194.

A Repercussão Geral e a competência recursal: riscos a serem ponderados in Revista Dialética de Direito Processual, São Paulo, nov. 2010, V. 92, pp. 33 39.

A Repercussão Geral e o novo papel do STF in Revista Dialética de Direito Processual, São Paulo, maio. 2007, V. 50, pp. 60-66.

ASSIS, Araken de. Manual dos Recursos. $2^{\mathrm{a}}$ ed. rev., atual. e ampl., São Paulo: Editora Revista dos Tribunais, 2008. 
ASSIS, Carlos Augusto de. Repercussão Geral como requisito de admissibilidade do recurso extraordinário (Lei 11418/2006) in Revista Dialética de Direito Processual, São Paulo, set. 2007, V. 54, pp. 32-46.

AURELLI, Arlete Inês. Repercussão Geral como requisito de admissibilidade do recurso extraordinário in Revista de Processo, São Paulo, set. 2007, V. 151, pp. 140-149.

AZEM, Guilherme Beux Nassif. Repercussão Geral da questão constitucional no recurso extraordinário. Porto Alegre: Editora Livraria do Advogado, 2009.

BARBOSA MOREIRA, José Carlos. Comentários ao Código de Processo Civil. Vol. V, $13^{\mathrm{a}}$ ed. rev. e atual., Rio de Janeiro: Editora Forense, 2007.

BEDAQUE, José Roberto dos Santos. Discricionariedade Judicial. in Revista Forense, São Paulo, mar./abr. 2001, v. 97, n. 354, pp. 187-195.

BEGA, Carolina Brambila. Repercussão Geral das questões constitucionais - Aspectos processuais. Tese (Doutorado), Faculdade de Direito da Universidade de São Paulo, 2008.

BENUCCI, Renato Luís. A Repercussão Geral no recurso extraordinário como instrumento de gestão judiciária in Revista Dialética de Direito Processual, São Paulo, jun. 2008, v. 63, pp. 116-125.

BERMUDES, Sérgio. Comentários ao Código de Processo Civil. Vol. 7, São Paulo: RT, 1977.

BONDIOLI, Luis Guilherme Aidar. Embargos de Declaração. Porto Alegre: Editora Livraria do Advogado, 2009. $1^{\text {a }}$ ed., São Paulo: Editora Saraiva, 2005.

BORGES, Marcos Afonso. O recurso extraordinário e a Repercussão Geral in Revista de Processo, São Paulo, fev. 2008, V. 156, pp. 36-44.

BRAGHITTONI, Rogério Ives. Acesso aos tribunais superiores: da argüição de relevância à Repercussão Geral. Tese (Doutorado), Faculdade de Direito da Universidade de São Paulo, 2006. 
BUENO, Cássio Scarpinella. Amicus Curiae no processo civil brasileiro: um terceiro enigmático. São Paulo: Saraiva, 2008.

CARDOSO, Oscar Valente. Repercussão Geral, questões constitucionais qualificadas e coisa julgada inconstitucional in Revista Dialética de Direito Processual, São Paulo, mar. 2009, V. 72, pp. 66-78.

CARNEIRO, Diogo Ciuffo. Os requisitos de admissibilidade dos recursos especial $e$ extraordinário e a sua ilegítima utilização como filtros recursais in Revista de Processo, São Paulo, jun. 2008, V. 160, pp. 205-232.

CASTILHO, Manoel Lauro Volkmer de. O recurso extraordinário, a Repercussão Geral e a súmula vinculante in Revista de Processo, São Paulo, set. 2007, V. 151, pp. 99-119.

COELHO, Gláucia Mara. Repercussão Geral da questão constitucional no processo civil brasileiro. Dissertação (Mestrado), Faculdade de Direito da Universidade de São Paulo, 2007.

CORREAA, Oscar Dias Corrêa. O Supremo Tribunal Federal, corte constitucional do Brasil. Rio de Janeiro: Forense, 1987.

COSTA, Regina Helena. Repercussão Geral e recurso extraordinário in Revista de Direito Tributário, São Paulo, 2010, V. 111, pp. 55-60.

CUNHA, Leonardo Carneiro da. A função do Supremo Tribunal Federal e a força de seus precedentes: enfoque nas causas repetitivas in PAULSEN, Leandro. Repercussão Geral no Recurso Extraordinário: estudos em homenagem à Ministra Ellen Gracie. Porto Alegre: Editora Livraria do Advogado, 2009, pp. 57-73.

CRUZ E TUCCI, José Rogério. Anotações sobre a Repercussão Geral como pressuposto de admissibilidade do Recurso Extraordinário (Lei $\left.n^{\circ} 11.418 / 2006\right)$ in Revista do Advogado, Ano XXVII, nº 92, 2007.

DANTAS, Bruno. Repercussão Geral: perspectivas históricas, dogmática e de direito comparado: questões processuais. Coord.: Nelson Nery Jr. e Teresa Arruda Alvim Wambier. $3^{a}$ ed. rev., atual. e ampl., São Paulo: Editora Revista dos Tribunais, 2012. 
DIDIER JUNIOR, Fredie. Tópicos sobre a última reforma processual (dezembro de 2006) Parte 1 in Revista de Processo, São Paulo, maio. 2007, V. 147, pp. 164-174.

Transformações do recurso extraordinário in FUX, Luiz; NERY JUNIOR, Nelson; WAMBIER, Teresa Arruda Alvim. Processo e Constituição: estudos em homenagem ao professor José Carlos Barbosa Moreira. São Paulo: Revista dos Tribunais, 2006, pp. 982-990.

DINAMARCO, Cândido Rangel. A função das cortes supremas na América Latina. v. 324, Rio de Janeiro: Editora Forense, 1998.

Capítulos de sentença. $5^{\text {a }}$ ed., São Paulo: Malheiros

Editores, 2013.

FÉRES, Marcelo Andrade. Impactos da Emenda Constitucional 45/2004 sobre o recurso extraordinário: a Repercussão Geral (ou transcendência) e a nova alínea d do inciso III do art. 102 da Constituição in Revista Dialética de Direito Processual, São Paulo, jun. 2006, V. 39, p.105-112.

FERRAZ, Taís Schilling. Repercussão Geral - muito mais que um pressuposto de admissibilidade in PAULSEN, Leandro. Repercussão Geral no Recurso Extraordinário: estudos em homenagem à Ministra Ellen Gracie. Porto Alegre: Editora Livraria do Advogado, 2009, pp. 77-107.

FONSECA, João Francisco Naves da. Exame dos fatos nos recursos extraordinário e especial. São Paulo: Saraiva, 2012.

FUX, Luiz. Repercussão Geral e o Recurso Extraordinário (Lei 11.418/2006 com entrada rm vigor 21.02.2007). em Disponível online http://biblioteca.universia.net/html_bura/verColeccion/params/id/37229.html. Acesso em $17 / 5 / 2012$.

GAIO JÚNIOR, Antônio Pereira. Considerações sobre a idéia da Repercussão Geral e a multiplicidade dos recursos repetitivos no STF e STJ in Revista de Processo, São Paulo, abr. 2009, V. 170, pp. 140-156. 
GOMES JUNIOR, Luiz Manoel. A Repercussão Geral da questão constitucional no recurso extraordinário - EC 45 in NERY JUNIOR, Nelson; WAMBIER, Teresa Arruda Alvim. Aspectos polêmicos e atuais dos recursos civis e assuntos afins. São Paulo: Revista dos Tribunais, 2006, pp. 263-316 (Aspectos Polêmicos e Atuais dos Recursos).

LAMY, Eduardo de Avelar. Repercussão Geral no recurso extraordinário: a volta da arguição de relevância? in Reforma do Judiciário (obra coletiva), São Paulo: Revista dos Tribunais, 2005.

LIMA, Márcio Vinícius J. de. Repercussão Geral não é solução digna para salvar STF. Disponível [on line $]$ em http://www.conjur.com.br/2007-set20/repercussao_geral_nao_solucao_digna_salvar_stf.

LEONEL, Ricardo de Barros. Reformas recentes do Processo Civil - comentário sistemático. São Paulo: Editora Método, 2007.

LUCON, Paulo Henrique dos Santos. Repercussão Geral - prequestionamento: ofensa indireta a Constituição Federal. Má fé e ignorância. Danos decorrentes da demora do processo - Parecer in Revista de Processo, São Paulo, mar. 2008, V. 157, pp. 345-368.

MACHADO, Hugo de Brito. Conhecimento do recurso extraordinário - Repercussão Geral das questões constitucionais in Revista Dialética de Direito Processual, São Paulo, jan. 2006, V. 34, pp. 41-52.

MANCUSO, Rodolfo de Camargo. A realidade judiciária brasileira e os tribunais da federação - STF e STJ: inevitabilidade de elementos de contenção dos recursos a eles dirigidos in FUX, Luiz; NERY JUNIOR, Nelson; WAMBIER, Teresa Arruda Alvim. Processo e Constituição: estudos em homenagem ao professor José Carlos Barbosa Moreira. São Paulo: Revista dos Tribunais, 2006, pp. 1068-1077.

Recurso Extraordinário e Recurso Especial. 11ª ed., rev., atual. e ampl. de acordo com as leis 11.417/2006, 11.418/2006, 11.672/2008 e emendas regimentais do STF e STJ. São Paulo, Revista dos Tribunais, 2010.

MARCATO, Ana Cândida Menezes. Contornos da Repercussão Geral, o novo requisito de admissibilidade do recurso extraordinário in CARMONA, Carlos Alberto. Reflexões sobre a 
reforma do Código de Processo Civil : estudos em homenagem a Ada Pelligrini Grinover, Cândido R. Dinamarco e Kazuo Watanabe. São Paulo: Editora Atlas, 2007, pp. 61-84.

MARINONI, Luiz Guilherme; MITIDIERO, Daniel. Repercussão Geral no recurso extraordinário. $3^{\mathrm{a}}$ ed. rev. e atual., São Paulo: Editora Revista dos Tribunais, 2012.

MARTINS, Samir José Caetano. A Repercussão Geral da questão constitucional (Lei 11418/2006) in Revista Dialética de Direito Processual, São Paulo, maio. 2007, V. 50, pp. 95111.

MARTINS, Sérgio Pinto. Direito processual do trabalho. $25^{\mathrm{a}}$ ed. rev. e atual., São Paulo: Atlas, 2006.

MARTINS FILHO, Ives Gandra da Silva, in Critério de Transcendência no recurso de revista - Projeto de Lei n. 3.267/00, in Revista LTr., volume 65, $\mathrm{n}^{\circ}$ 08, agosto/2001.

MATOS, Roberto de Assis. Repercussão Geral - análise crítica. Disponível [on line] em http://jusvi.com/artigos/38762.

MEDINA, José Miguel Garcia. Prequestionamento e Repercussão Geral e outras questões relativas aos recursos especial e extraordinário. Coord.: Nelson Nery Jr. e Teresa Arruda Alvim Wambier. $5^{\text {a }}$ ed. rev. e atual., São Paulo: Editora Revista dos Tribunais, 2009.

MEDINA, José Miguel Garcia; WAMBIER, Luiz Rodrigues e WAMBIER, Teresa Arruda Alvim. Repercussão Geral e Súmula Vinculante in Reforma do Judiciário (obra coletiva), São Paulo: Revista dos Tribunais, 2005.

MEDINA, José Miguel Garcia; WAMBIER, Luiz Rodrigues e WAMBIER, Teresa Arruda Alvim. Repercussão Geral no recurso extraordinário in Breves Comentários à Nova Sistemática Processual Civil, São Paulo: Revista dos Tribunais, 2007.

MORELLO, Augusto M. La nueva etapa del recurso extraordinario: el "certiorari”. Buenos Aires: Platense, 1990. Apud GOMES JÚNIOR, Luiz Manoel. A Repercussão Geral da questão constitucional no recurso extraordinário in Revista de Processo, v. 119. 
NEGRÃO, Theotonio; GOUVÊA, José Roberto F.; BONDIOLI, Luis Guilherme A.; FONSECA, João Francisco Naves. Código de Processo Civil e Legislação Processual em vigor. $43^{\mathrm{a}}$ ed. atual. e reform., São Paulo: Editora Saraiva, 2012.

PITMAN, Mildred Lima. A Repercussão Geral como requisito de admissibilidade do recurso extraordinário in Revista Dialética de Direito Processual, São Paulo, set. 2006, V. 42, pp. 126-141.

PROTO PISANI, Andrea. Crisi della Cassazione: la (non più rinviabile) necessitá di una scelta in RePro, ano 33, nº 157, mar/2008, pp. 261-267.

RAMOS, Guillermo Federico. A cláusula da Repercussão Geral como pressuposto de admissibilidade do recurso extraordinário in Revista de Processo, São Paulo, out. 2008, V. 164, pp. 367-376.

REICHELT, Luis Alberto. A duração do processo, o julgamento do recurso extraordinário dotado de Repercussão Geral e a modulação dos efeitos da declaração de inconstitucionalidade in Revista de Processo, São Paulo, mar. 2011, V. 193, pp. 131-152.

A Repercussão Geral do recurso extraordinário e a construção do processo civil na era da solidariedade social in Revista de Processo, São Paulo, nov. 2010, V. 189, pp. 88-100.

REIS, José Carlos Vasconcellos dos. Apontamentos sobre o novo perfil do recurso extraordinário no direito brasileiro in Revista de Processo, São Paulo, out. 2008, V. 164, pp. 57-83.

RIBEIRO, Flávia Pereira. A exigência da preliminar de Repercussão Geral em apartado in Revista de Processo, São Paulo, set. 2010, V. 187, pp. 239-248.

ROCHA, Fabiano de Bem da Rocha. Análise crítica da Repercussão Geral constitucional e sua arguição no recurso extraordinário de questões relativas à propriedade industrial in ROCHA, Fabiano de Bem da. Capítulos de processo civil na propriedade intelectual. Rio de Janeiro: Editora Lumen Juris, 2009, pp. 325-351.

RODRIGUES NETTO, Nelson. A alteração do regimento interno do Supremo Tribunal Federal para a aplicação da Repercussão Geral da questão constitucional no recurso 
extraordinário in Revista Dialética de Direito Processual, São Paulo, jul. 2007, V. 52, pp. 108-115.

A aplicação da Repercussão Geral da questão constitucional no recurso extraordinário consoante a Lei 11418/06 in Revista Dialética de Direito Processual, São Paulo, abr. 2007, V. 49, pp. 112-129.

A intervenção de terceiros nos julgamentos da Repercussão Geral do recurso extraordinário e do recurso especial paradigmático in DIDIER JUNIOR, Fredie et.al. O terceiro no processo civil brasileiro e assuntos correlatos. São Paulo: Editora Revista dos Tribunais, 2010. pp. 383-397.

SCHLOSSER, Lizelote e WICKERT, Lisiane Beatriz. $\underline{\text { A inserção e a regulamentação da }}$ Repercussão Geral como pressuposto de admissibilidade do recurso extraordinário in Revista de Processo, São Paulo, jul. 2008, V. 161, pp. 115-134.

SERAU JR., Marco Aurélio e DONOSO, Denis. Relevância da questão federal como filtro de admissibilidade do recurso especial: análise das propostas de emenda constitucional $n$. 209/2012 e n. 17/2013 in Revista de Processo, São Paulo, out. 2013, v. 224, pp. 241-248.

SILVA, Bruno Mattos e. Normatização da Repercussão Geral no recurso extraordinário in Revista Brasileira de Direito Processual, Belo Horizonte, abr./jun. 2008, V. 62, pp. 39-53.

SILVA, Ticiano Alves e. Apreciação pelo juízo a quo da existência de alegação de Repercussão Geral in Revista de Processo, São Paulo, jul. 2008, V. 161, pp. 135-153.

TALAMINI, Eduardo. Repercussão Geral em recurso extraordinário: nota sobre sua regulamentação in Revista Dialética de Direito Processual, São Paulo, set. 2007, V. 54, pp. $56-68$.

. Novos aspectos da jurisdição constitucional brasileira: Repercussão Geral, força vinculante, modulação dos efeitos do controle de constitucionalidade e alargamento do objeto do controle direto. Tese apresentada para o concurso à livre-docência do Departamento de Direito Processual - Área de Direito Processual Civil. Faculdade de Direito da Universidade de São Paulo, 2008. 
TANIGUCHI, Yasuhei. O Código de Processo Civil japonês de 1996 - um processo para o próximo século in Revista de Processo, vol. 99.

THEODORO JÚNIOR, Humberto; NUNES, Dierle; BAHIA, Alexandre. Litigiosidade em massa e Repercussão Geral no recurso extraordinário in Revista de Processo, São Paulo, nov. 2009, V. 177, pp. 9-46.

Repercussão Geral no Recurso Extraordinário (Lei $n^{o}$ 11.148) e Súmula Vinculante do Supremo Tribunal Federal (Lei $\left.n^{\circ} 11.417\right)$, in RDCPC $\mathrm{n}^{\circ} 48$, Julho-Agosto/2007.

Curso de Direito processual Civil - Teoria geral do direito processual e processo de conhecimento. $48^{\mathrm{a}}$ ed., Rio de Janeiro: Editora Forense, 2008.

TIMM, Luciano Benetti; TRINDADE, Manoel Gustavo Neubarth. As recentes alterações legislativas sobre recursos aos Tribunais Superiores: a Repercussão Geral e os processos repetitivos sob a ótica da law and economics in Revista de Processo, São Paulo, dez. 2009, V. 178, pp. 153-179.

SOBRINHO, Suian Alencar. Ocaso do julgamento a varejo: comentários sobre a Lei $n$. 11.418/2006. Disponível [on line] em http://jus2.uol.com.br/doutrina/texto.asp?id=9356.

URBANO, Hugo Evo Magro Corrêa. Da arguição de relevância à Repercussão Geral das questões constitucionais no recurso extraordinário in Revista Dialética de Direito Processual, São Paulo, fev. 2007, V. 47, pp. 61-78.

VIANA, Juvêncio Vasconcelos. Questão de Repercussão Geral (parágrafo 3 do art. 102 da Constituição Federal) e a admissibilidade do recurso extraordinário in Revista Dialética de Direito Processual, São Paulo, set. 2005, V. 30, pp. 72-84.

VIANA, Ulisses Schwarz. Repercussão Geral sob a ótica da teoria dos sistemas de Niklas Luhmann. $2^{a}$ ed., São Paulo: Editora Saraiva, 2011.

YOSHIKAWA, Eduardo Henrique de Oliveira. A Repercussão Geral do recurso extraordinário: uma volta ao passado in Revista Dialética de Direito Processual, São Paulo, ago. 2007, V. 53, pp. 44-55. 
STF REGULA APLICAÇÃO DA REPERCUSSÃO GERAL À JURISPRUDÊNCIA PACIFICADA DA CORTE, in Diário de Notícias, Ano XXII, São Paulo, nº 4272.

http://www.stf.gov.br/portal/jurisprudenciaRepercussaoGeral/arquivo/estudoRepercussaoGera $\underline{1 . p d f}$.

RELATÓRIO DA REPERCUSSÃO GERAL - MARÇO DE 2010. Disponível [on line] em http://www.stf.jus.br/arquivo/cms/jurisprudenciaRepercussaoGeralRelatorio/anexo/Relatorio RG_Mar2010.pdf.

RELATÓRIO DA REPERCUSSÃO GERAL - JULHO DE 2009. Disponível [on line] em http://www.stf.jus.br/arquivo/cms/jurisprudenciaRepercussaoGeralRelatorio/anexo/Relatorio RG_Jul2009.pdf.

RELATÓRIO DE ATIVIDADES 2008 - STF. Disponível [on line $]$ em http://www.stf.jus.br/arquivo/cms/sobreStfConhecaStfRelatorio/anexo/STF_Relatorio_de_Ati vidades_2008_capa2.pdf.

“MAIS SELETIVO E EFICIENTE”, artigo extraído da Revista Veja, edição de 22 de julho de 2009.

“WHEN LESS IS MORE”, artigo extraído da revista The Economist, edição de 21 de maio de 2009. Disponível [on line $]$ em http://www.economist.com/displayStory.cfm?story_id=13707663. 